\title{
Columbia River Monitoring: Distribution of Tritium in Columbia River Water at the Richland Pumphouse
}

\author{
R. L. Dirkes
}

February 1993

Prepared for the U.S. Department of Energy under Contract DE-AC06-76RLO 1830

Pacific Northwest Laboratory Operated for the U.S. Department of Energy by Battelle Memorial Institute
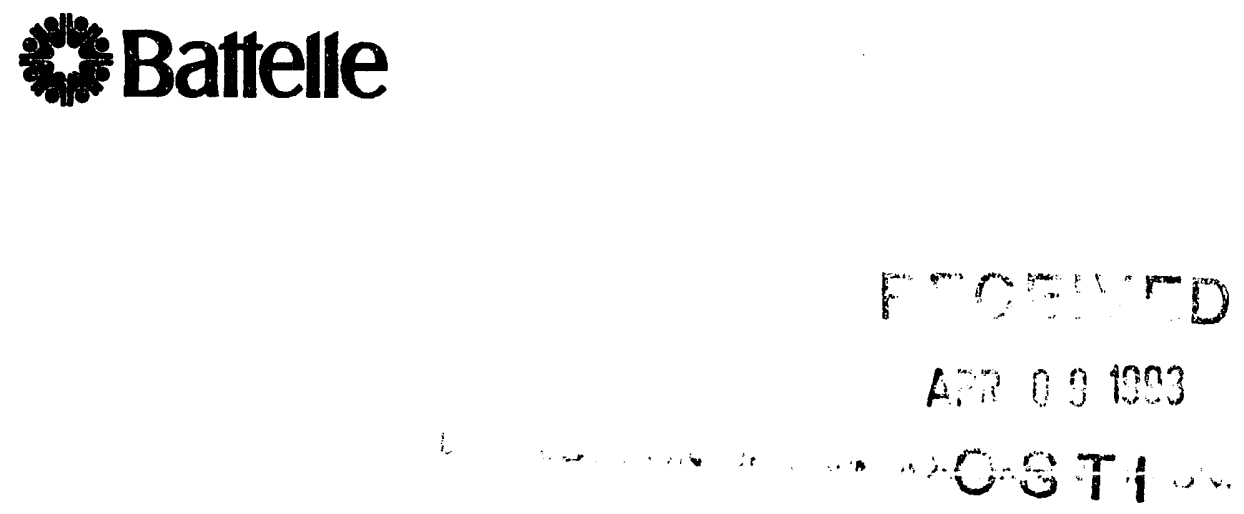


\title{
DISCLAIMER
}

This report was prepared as an account of work sponsored by an agency of the United States Government. Neither the United States Government nor any agency thereof, nor Battelle Memorial Institute, nor any of their employees, makes any warranty, expressed or implied, or assumes any legal liability or responsibility for the accuracy, completeness, or usefulness of any information, apparatus, product, or process disclosed, or represents that its use would not infringe privately owned rights. Reference herein to any specific commercial product, process, or service by trade name, trademark, manufacturer, or otherwise does not necessarily constitute or imply its endorsement, recommendation, or favoring by the United States Government or any agency thereof, or Battelle Memorial Institute. The views and opinions of authors expressed herein do not necessarily state or reflect those of the United States Government or any agency thereof.

\author{
PACIFIC NORTHWEST LABORATORY \\ operated by \\ BATTELLE MEMORIAL INSTITUTE \\ for the \\ UNITED STATES DEPARTMENT OF ENERGY \\ under Contract DE-AC06-76RLO 1830
}

Printed in the United States of America

Available to DOE and DOE contractors from the

Office of Scientific and Technical Information, P.O. Box 62, Oak Ridge, TN 37831; prices available from (615) 576-8401. FTS 626-8401.

Available to the public from the National Technical Information Service, U.S. Department of Commerce, 5285 Port Royal Rd., Springfield, VA 22161. 
COLUMBIA RIVER MONITORING: DISTRIBUTION OF TRITIUM IN COLUMBIA RIVER WATER

AT THE RICHLAND PUMPHOUSE

\author{
R. L. Dirkes
}

February 1993

Prepared for the U.S. Department of Energy under Contract DE-AC06-76RLO 1830

Pacific Northwest Laboratory Richland, Washington 99352

\title{
MASTER
}




\section{SUMMARY}

The Surface Environmental Surveillance Project (SESP) is conducted by the Pacific Northwest Laboratory (PNL) for the U.S. Department of Energy (DOE). This report presents the results of a special study conducted as part of the SESP to supplement the routine Columbia River monitoring program and provide information relative to the dispersion and distribution of Hanfordorigin contaminants entering the river through the seepage of ground water along the Hanford Site.

Sampling was conducted along cross sections to determine the distribution of tritium within the Columbia River at Richland, Washington. The investigation was also designed to evaluate the relationship between the average tritium concentrations in the river water at this location and in water collected from the routine SESP river monitoring system located at the city of Richland drinking water intake (Richland Pumphouse).

This study was conducted during the summers of 1987 and 1988 . Water samples were collected along cross sections located at or near the Richland Pumphouse monitoring station. Samples were collected simultaneously from the routine river monitoring system located at the Richland Pumphouse. Sampling was conducted under low flow conditions during 1987 to minimize diiution and maximize the potential impact of Hanford contaminants entering the river. During 1988, sampling was conducted under low, average, and high flows to better understand the influence of river discharge on the distribution of tritium in the river downstream of Hanford.

Tritium concentrations were highest near the Benton County shoreline, Hanford side of the river, under certain river flow conditions. The concentrations of tritium generally decreased to background levels with distance across the river. Tritium concentrations in samples collected from the routine monitoring system at the Richland Pumphouse were consistently elevated when compared with average river concentrations as determined through crosssectional sampling. As expected, impacts were greatest during low river flow conditions. 


\section{ACKNOWLEDGMENTS}

A special thanks to the Environmental Monitoring Group for sample collection; to W. H. Walters and R. K. Woodruff for technical review; to the Sigma $V$ Text Processing Team for word processing support; to J. B. Flynn for initial editing; and to M. K. DeSmet and R. E. Lundgren for final editing and report production. 


\section{CONTENTS}

SUMMARY

ACKNOWLEDGMENTS ....................

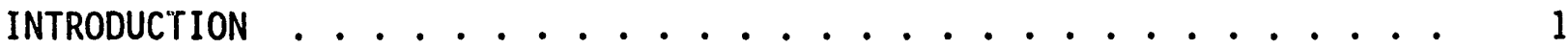

BACKGROUND INFORMATION ................. 3

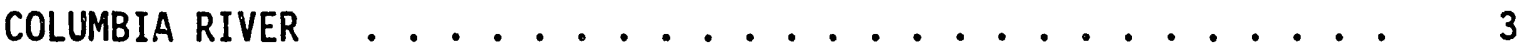

HANFORD OPERATIONS $\ldots \ldots \ldots \ldots \ldots$

GROUND-WATER SURVEILLANCE ................ 6

SURFACE-WATER SURVEILLANCE $\ldots \ldots \ldots \ldots$

STUDY DESCRIPTION . . . . . . . . . . . . . 15

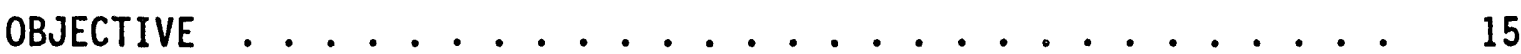

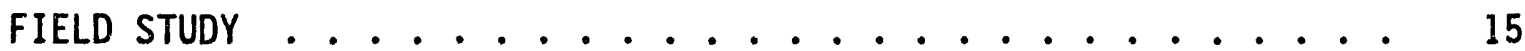

Constituents of Interest ............ 17

River flow .................... 18

Transect Locations . . . . . . . . . . . . 19

Equipment ................ 22

Field Measurements .............. 24

Sample Collection ................. 28

Sample Analysis .................. 29

Data Analysis ................. 29

QUALITY CONTROL ........................ 30

RESULTS AND DISCUSSION ................. 33

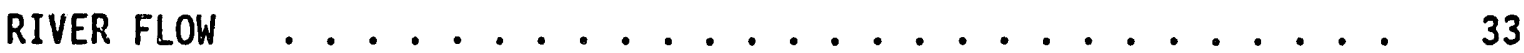

BATHYMETRIC SURVEYS ................ 36

CURRENT VELOCITY ....................... 37 
TRITIUM CONCENTRATIONS ......................... 39

$1987 \ldots \ldots \ldots \ldots$

$1988 \ldots \ldots \ldots \ldots \ldots$

Average Tritium Concentrations .......... 45

CONCLUSIONS ........................... 51

REFERENCES ..................... 53

APPENDIX A - RIVER FLOW, CURRENT VELOCITY, AND TRITIUM

CONCENTRATION DATA . ..................... A.

APPENDIX B - ADDITIONAL ANALYSES .............. B.1

APPENDIX C - QUALITY CONTROL/DUPLICATE SAMPLE RESULTS . . . . . . . C.1 


\section{FIGURES}

1 U.S. Department of Energy's Hanford Site . . . . . . . . 4

2 Tritium Distribution in the Unconfined Aquifer at Hanford, 1980 Through $1990 \ldots \ldots$............... 8

3 Tritium Concentrations in Columbia River Water at Priest Rapids Dam and the Richland Pumphouse, 1982 Through $1990 \ldots \ldots$. . . . . . . . . . .

4 Difference in Annual Average Tritium Concentrations at Priest Rapids Dam and the Richland Pumphouse,

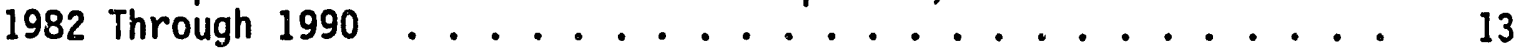

5 Schematic of Cross Section Sampling Plan ......... 16

6 Transect Locations ................. 20

7 Sample Vessel and Equipment .............. 23

8 Sample Intake and Current Meter Configuration ......... 26

9 Typical Fathometer Calibration Chart .......... 27

10 Water Sampling System Schematic . . . . . . . . . . . 29

11 Daily Average Discharge, Columbia River at Priest Rapids Dam, August 17, 1987 Through September 15, 1987 . . . . . . . 34

12 Daily Average Discharge, Columbia River at Priest Rapids Dam, June 1988 Through Oc'cober 1988 . . . . . . . 35

13 Richland Ferry Landing Transect Fathometer Chart . . . . . . 37

14 Richland Pumphouse Transect Fathometer Chart ......... 38

15 Tritium Concentrations Along the Richland Ferry Landing Cross Section, 1987 ............... 40

16 Comparison of Tritium Concentrations Along the Richland Ferry Landing Cross Section and at the Richland Pumphouse, 1987 .............. 42

17 Tritium Concentrations Versus Depth Along the Richland Ferry Landing Cross Section, August 27, 1987 ...... 43

18 Tritium Concentrations Along the Richland Pumphouse Cross Section, 1988 
19 Comparison of Tritium Concentrations Along the

Richland Pumphouse Cross Section and at the

Richland Pumphouse, 1988 ................ 46

20 Average Cross Section Tritium Concentration Versus

Average Richland Pumphouse Tritium Concentration . . . . . . . 47

21 Bias in Tritium Concentrations Measured Along

the Cross Section and the Richland Pumphouse .......... 48

APPENDIX C

C.1 Duplicate Sample Tritium Analysis, August 27, 1987 . . . . . . C.3

C.2 Duplicate Sample Tritium Analysis, August 31, 1987 . . . . . C.3

C.3 Duplicate Sample Tritium Analysis, September 10, 1987 . . . . . C.4

C.4 Duplicate Sample Tritium Analysis, June 23, 1988 . . . . . . . C.4

C.5 Duplicate Sample Tritium Analysis, August 5, 1988 . . . . . . C.5

C.6 Duplicate Sample Tritium Analysis, September 29, 1988 . . . . . C.5 


\section{TABLES}

\section{APPENDIX A}

A.1 Daily Average Columbia River Flows, August 17, 1987

Through September 15, 1987

A.2 Daily Average Columbia River Flows, June 13, 1988

Through June 28, 1988 . . . . . . . . . . . . . . .

A.3 Daily Average Columbia River Flows, July 26, 1988

Through August 10, 1988

A.4 Daily Average Columbia River Flows, September 19, 1988

Through October 4, 1988 . . . . . . . . . . . . A.4

A.5 Annual Average Columbia River Flows, 1980-1990 . . . . . . . A.5

A.6 Velocity Measurements Along Richland Ferry Landing

Cross Section, August 27, 1987 ............... A.6

A.7 Vertically Averaged Velocity for Each Richland Ferry

Landing Transect Station, August 27, 1987 . . . . . . . . . A.7

A.8 Vertically Averaged Velocity for Each Richland Ferry Landing Transect Station, August 31, 1987 . . . . . . . . . A.8

A.9 Vertically Averaged Velocity for Each Richland Ferry Landing Transect Station, September 10,1987 . . . . . . . . A.9

A.10 Vertically Averaged Velocity for Each Richland Pumphouse Transect Station, June 23, 1988 . . . . . . . . . . . A.10

A.11 Vertically Averaged Velocity for Each Richland Pumphouse Transect Station, August 5, 1988

A.12 Vertically Averaged Velocity for Each Richland Pumphouse Transect Station, September 29, 1988 . . . . . . . . . A.12

A.13 Tritium Concentrations Along Richland Ferry Landing Cross Section and at the Richland Pumphouse, August 27, 1987 . A.13

A.14 Tritium Concentrations at Various Depths at Selected Stations Along the Richland Ferry Landing Cross Section, August 27, 1987

A.15 Tritium Concentrations Along Richland Ferry Landing Cross Section and at the Richland Pumphouse, August 31, 1987 
A.16 Tritium Concentrations Along Richland Ferry Landing Cross Section and at the Richland Pumphouse,

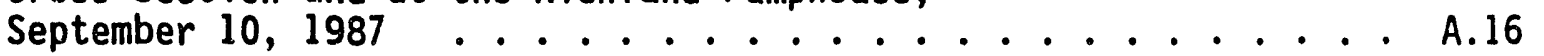

A.17 Tritium Concentrations Along Richland Pumphouse

Cross Section and at the Richland Pumphouse, June 23, 1988 . . A.17

A.18 Tritium Concentrations Along Richland Pumphouse

Cross Section and at the Richland Pumphouse, August 5, 1988 . . A.18

A.19 Tritium Concentrations Along Richland Pumphouse Cross

Section and at the Richland Pumphouse, September 29, 1988 . . . A.19

A.20 Average Tritium Concentrations Measured Along Cross-Sections near the Richland Pumphouse and with the Richland Pumphouse Monitoring System ........ A.20

\section{APPENDIX B}

B.1 Comparison of Selected Radionuclide Concentrations at

Cross Section Stations and the Richland Pumphouse ....... B.2

B.2 Richland Ferry Landing Cross Section pH and Conductivity, 1987 . B.3

B.? Richland Pumphouse Cross Section pH and Conductivity, 1988 . . B.4 APPENDIX C

C.1 Quality Control: Duplicate Sample Results .......... C.2 


\section{INTRODUCTION}

The Surface Environmental Surveillance Project (SESP) is conducted by the Pacific Northwest Laboratory (PNL) for the U.S. Department of Energy $(D O E)$. The routine Columbia River monitoring program, conducted as part of the SESP, provides a historical record of contaminant concentrations in the river attributable to natural causes, worldwide fallout resulting from past atmospheric testing of nuclear weapons, and operations conducted at the Hanford Site. In addition to routine monitoring, special studies are conducted periodically to enhance the understanding of the transport and fate of contaminants in the river. Special studies also provide information necessary to accurately evaluate the routine monitoring data.

This report presents the results of a special study, conducted as part of the SESP, to determine the distribution of tritium within the Columbia River at Richland, Washington. The investigation was also designed to evaluate the relationship between the average tritium concentrations in the river water at this location and in water collected from the routine SESP monitoring system located at the city of Richland drinking water intake (Richland Pumphouse). This study was conducted during the summers of 1987 and 1988 to supplement the routine monitoring program and fulfill recommendations provided in applicable monitoring guidance.

This report provides background information useful in understanding the rationale and reasoning behind this investigation. The introductory material is followed by a description of the study, discussion of the results, and conclusions based on the study findings. Data, which are discussed and displayed graphically in the text, are presented in tabular form in the appendices. 


\section{BACKGROUND INFORMATION}

The Hanford Site, established in 1943, is located in southeastern Washington, occupying an area of approximately 560 square miles. The Site lies approximately 170 miles southeast of Seattle, Washington; 125 miles southwest of Spokane, Washington; and 200 miles northeast of Portiand, Oregon (Figure 1). The Columbia River, which origi tes in the mountains of eastern British Columbia, Canada, flows through the northern edge of the Hanford Site and forms part of the Site's eastern boundary. The flow of the Columbia River is regulated by 11 dams within the United States, seven upstream and four downstream of the Site. Priest Rapids is the nearest dam upstream of the Site, and McNary is the nearest dam downstream. The Hanford Reach of the Columbia River extends from Priest Rapids Dam to the head of Lake Wallula (craated by McNary Dam) near Richland. This stretch of the Columbia River is the last in the United States above Bonneville Dam that remains unimpounded.

\section{COLUMBIA RIVER}

Columbia River discharges fluctuate significantly as a result of the relatively small storage capacities and operational practices of the nearby upstream dams. Flows through the Reach are dictated primarily by operations at Priest Rapids Dam. Annual average flows at Priest Rapids Dam over the last 68 years have averaged nearly 120,000 cubic feet per second (cfs) (McGavock et a1. 1987). Daily average flows range from 36,000 cfs to 250,000 cfs. Monthly mean flows typically peak from April through June and are lowest from September through October. As a result of the fluctuations in discharges (hydropeaking), the depth of the river varies significantly over time. Fluctuations of greater than 5 vertical feet are not uncommon along the Reach.

The primary uses of the Columbia River include the production of hydroelectric power and extensive irrigation of nearby farmland. Several communities located on the Columbia River rely on the river as their source of drinking water. Water from the Columbia River along the Hanford Reach is also used as a source of drinking water by several onsite facilities and for 


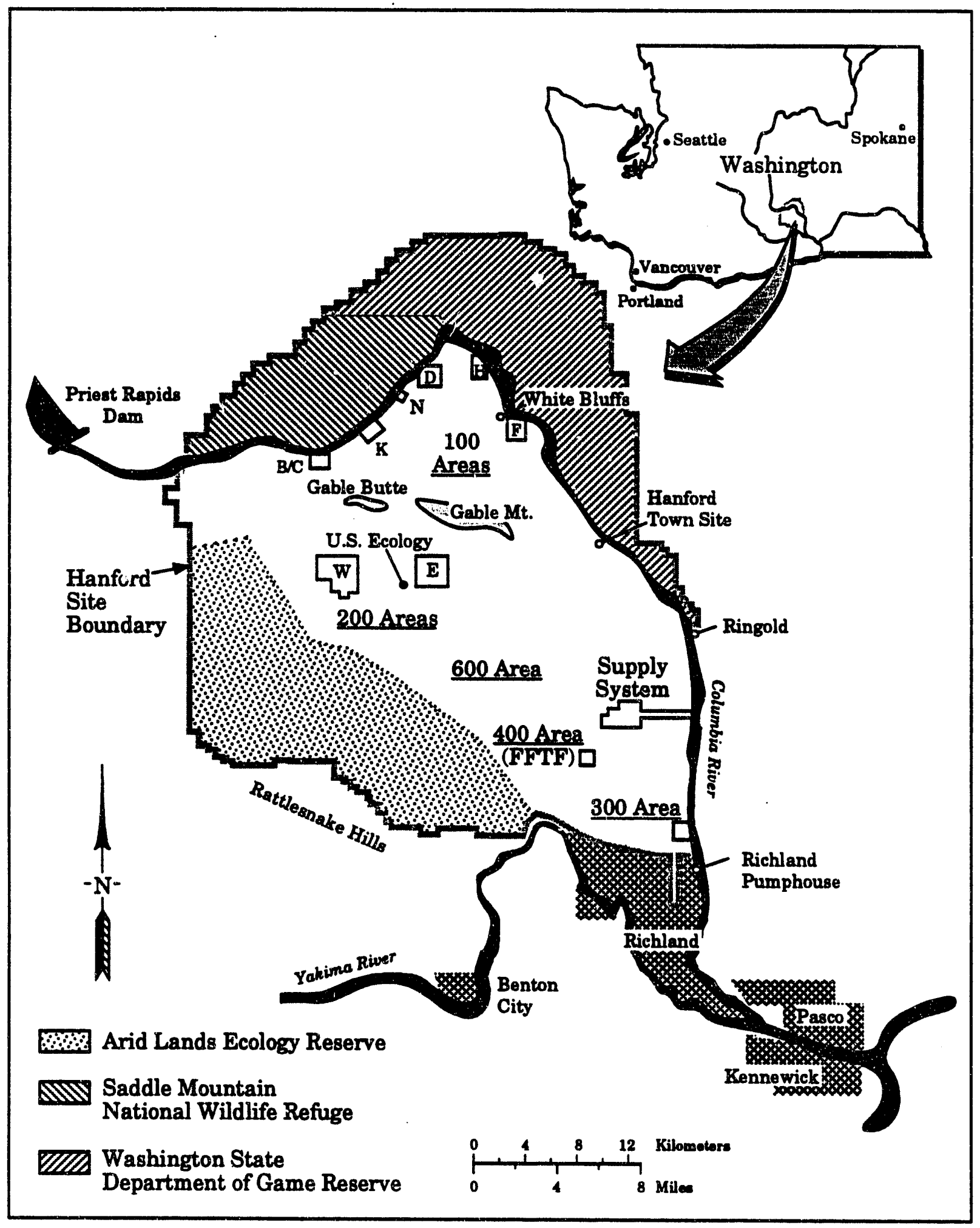

S9111080.28

FIGURE 1. U.S. Department of Energy's Hanford Site 
industrial uses. In addition, the Columbia is used extensively for recreational activities such as fishing, hunting, boating, sailboarding, and swimming.

The state of Washington has designated the Columbia River along this stretch as Class A, Excellent (WDOE 1982). Water quality criteria have been established and water use guidelines provided for this class designation. As such, the water is to be suitable for essentially all uses, including raw drinking water, recreation, and wildlife habitat.

\section{HANFORD OPERATIONS}

The Hanford Site was established to design, build, and operate nuclear reactors for the production of special nuclear materials. Contributing factors in the selection of Hanford as the site for these operations were the remoteness of the region, the lack of large populations, and the presence of the Columbia River, which could provide the large volumes of cooling water needed for reactor operations. Nine production reactors have operated along the banks of the Columbia since the Site was established. Eight of these reactors used once-through-cooling systems, which resulted in the release of heated water, corrosion-inhibiting chemicals, and radionuclides, primarily activation products, directly into the river. All eight of the once-throughcooling system reactors were deactivated between December 1964 and January 1971. The shutdown of these reactors resulted in a tremendous decrease in the amount of radioactivity released into the Columbia (Cushing et al. 1981; Becker 1990). The $\mathbf{N}$ Reactor, a production reactor remaining in operation through 1988, operated with a closed-loop cooling system that resulted in a significant amount of heat being discharged directly into the Columbia River but with very little radioactivity associated with it. With the shutdown of the $N$ Reactor, direct discharges of contaminants into the Columbia River were virtually eliminated.

Direct discharges to the river are monitored by the operating contractor of the facility responsible for the discharge. Direct discharges are permitted under the National Pollutant Discharge Elimination System (NPDES) process (Clean Water Act 1977). Monthly monitoring reports are generated for 
each of the direct discharges associated with Hanford operations. The NPDES permits address only nonradiological constituents present in the discharge waters. Radiological discharges are also monitored by the operating contractor and must be reported under DOE effluent monitoring and reporting requirements (DOE 1987). In addition to monitoring the discharges, the operating contractor alsc performs some limited environmental monitoring activities to confirm the adequacy of effluent control and monitoring systems. Such is the case at the 100-N Area, where periodic riverbank spring sampling is conducted by Westinghouse Hanford Company to determine and ensure the representativeness of the existing effluent monitoring program (Rokkan 1988).

In addition to liquid discharges to the river, large volumes of wastewater were generated and discharged to the ground as a result of operations at Hanford. The disposal of this liquid effluent to the ground has impacted greatly the unconfined aquifer beneath the Site. The movement of ground water and the associated contaminants has changed over time as a result of the variation in both the volumes and composition of the wastewater. In general, the predominant flow pattern of Hanford ground water is from the recharge areas in the west to the discharge areas (primarily the Columbia River) in the east (Freshley and Graham 1988).

\section{GROUND-WATER SURVEILLANCE}

The Ground-Water Protection and Monitoring Project (GWPMP), operated by PNL for the DOE, is responsible for monitoring the ground water beneath the Hanford Site. Monitoring is performed via a network of sampling wells located throughout the Site. Results of the ground-water monitoring activities and sample results are reported in a series of semi-annual and annual ground-water monitoring reports (Evans et a1. 1989a, 1989b, 1992). Recent7y, the groundwater monitoring and surface environmental monitoring data have been combined in a single Hanford Site environmental monitoring report (Jaquish and Bryce 1990). While this program has historically been primarily interested in radioactive pollutants in the ground water, nonradiological contaminants have also been monitored during the past few years. 
In addition to the routine site-wide ground-water monitoring project, several hazardous waste ground-water monitoring compliance projects are ongoing in conjunction with the Resource Conservation and Recovery Act (RCRA) at various locations onsite that provide information relative to contaminant concentrations in the ground water beneath the Site. Two such projects are currently being conducted in areas near the river, one in the 100-H Area and the other in the 300 Area. These projects provide an extensive amount of information relative to the contaminants present in the ground water entering the river along these areas (Liikala et al. 1988; Schalla et al. 1988). In addition to RCRA investigations, there are several Comprehensive Environmental Response, Compensation and Liability Act (CERCLA) remedial investigation/feasibility study activities ongoing at Hanford, some of which are directly related to contaminants in the river and the transport of contaminants through the ground water into the river. These investigations provide additional information concerning contaminants of interest along the river as well as identifying those contaminants that are currently entering the river through the discharge of contaminated ground water from the Site (DDE 1992).

Monitoring data have shown several contaminants to be present in the ground water beneath waste disposal sites. The data also indicate that several of these contaminants are mobile in the ground-water system and travel at various rates through the unconfined aquifer, eventually to discharge to the Columbia River. Tritium and nitrate are the primary constituents used in determining the extent of the contaminated ground water onsite because they are present in easily measurable quantities and they move through the ground water virtually unimpeded. Figure 2 shows the distribution of tritium in the unconfined aquifer, resulting from the 200 Area operations, during the years 1980 through 1990, illustrating the migration of contaminants away from waste disposal areas toward the Columbia River. The extent of the contaminated ground-water discharge into the Columbia River has expanded over time, encompassing a larger portion of the Hanford shoreline, generally in a southern direction, nearer the routine river water sampling location at the Richland Pumphouse. 

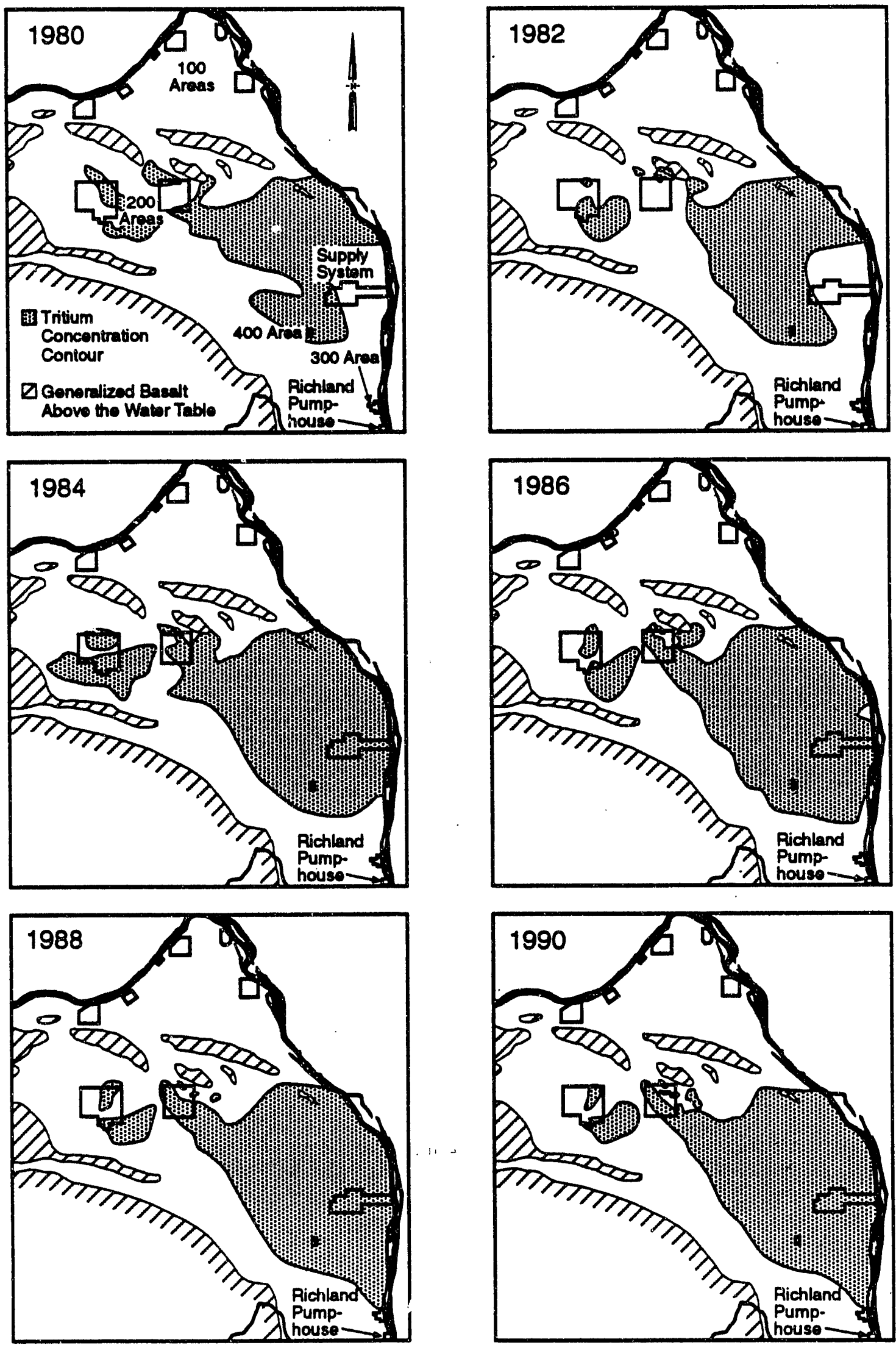

59209063.7

FIGURE 2. Tritium Distribution in the Unconfined Aquifer at Hanford, 1980 Through 1990 
Ground-water discharges, or springs, were documented along what is now known as the Hanford Reach long before the startup of Hanford operations (Jenkins 1922). More recently, 115 springs or seepage areas were identified during a survey of approximately 41 miles of Hanford shoreline (McCormack and Carlile 1984). This survey, conducted during 1982 and 1983, included all shoreline areas potentially affected by contaminated ground water beneath Hanford, as defined by annual ground-water monitoring data reports. Unlike earlier springs, which likely resulted from bank storage and irrigation application, springs along the river following the establishment of the Hanford Site were largely influenced by the disposal of large volumes of liquid wastes to the ground.

These relatively small springs flow intermittently, apparently influenced primarily by the changes in the river level. During periods of high river stage, the flow of ground water may be temporarily reversed with river water infiltrating the riverbank (Raymond and Brown 1963). This phenomena, referred to as bank storage, is a key factor in sample collection and data interpretation. The interface between the ground water and the Columbia River is highly complex and not well defined. Seepage above the river level is considered to be just a fraction of the total amount of ground water entering the river along the Hanford Reach. The exchange of contaminants between the ground water and the river through the river bottom is not well understood.

\section{SURFACE-WATER SURVEILLANCE}

The SESP is responsible for the routine monitoring of the Hanford Site surface waters, including the Columbia River and the riverbank springs entering the river along the Hanford Reach. Results of environmental surveillance activities were reported in quarterly status reports from 1946 through 1957. Since 1957, results of the monitoring programs have been documented in annual Hanford Site Environmental Reports, the latest of which was issued in 1992 (Woodruff et a1. 1992).

Contaminants are known to enter the river via riverbank springs along the Hanford Reach (Dirkes 1990; McCormack and Carlile 1984; Rokkan 1988). Special studies conducted during the past 10 years have confirmed the 
discharge of the contaminated 200 Area ground-water plume into the river and the expansion of the plume toward the 300 Area, nearer the Richland Pumphouse Columbia River water sampling location (Dirkes 1990; McCormack and Carlile 1984). Radionuclide concentrations found during these special studies were indicative of those observed in ground water near the riverbank spring sampling sites.

The volume of the ground water discharged to the river along the entire Hanford Reach has not been quantified. However, estimates of the ground-water discharge in specific areas along the Site have been reported. The $N$ Springs, adjacent to the 100-N Area, discharged approximately 14,700,000 $\mathrm{ft}^{3}$ during 1987 , or an average flowrate over the year of about 0.5 cfs (Rokkan 1988). The contaminated ground-water discharge to the river near the Hanford Townsite, approximately 20 miles downstream of the $100-\mathrm{N}$ Area, resulting from past waste disposal practices in the 200 Areas has been estimated to be approximately $3.0 \mathrm{cfs}$ (Cline et al. 1985). These two areas have been identified as major discharge zones for contaminated Hanford ground water. Based on these estimates, the total flow of contaminated ground water into the Columbia River is apparently very small when compared to the flow of the Columbia River. Recent annual average river discharges have ranged from 100,000 to 140,000 cfs. The long-term average annual flow at Priest Rapids Dam, based on 68 years of record, is 120,000 cfs (McGavock et a1. 1987).

The Columbia River has been monitored at Hanford since 1945, shortly after the startup of the original plutonium production reactors. Samples have been collected routinely from several locations over the years including stations upstream of the Site, along the Hanford Reach, and downstream of the Site. The primary emphasis of the Columbia River monitoring program has been the evaluation of the potential radiation dose to those persons living near to and using the river. Questions about how representative shoreline river sampling locations were with respect to the overall river were addressed very early in the monitoring effort. In addition to the routine sample locations, cross-sectional sampling at numerous transect locations was conducted during the years of peak liquid effluent discharges to observe the channeling of reactor effluent within the river, better understand the dispersion 
characteristics of the river, and accurately interpret data obtained from single-point monitoring stations located on the river (Soldat 1962).

Numerous studies have investigated the mixing characteristics of the river and the dispersion of contaminants entering the river along the Hanford Reach (Backman 1962; Haney 1957; Honstead 1954; Honstead 1957; Honstead et a1. 1951; Norton 1957; Sonnichsen et a1. 1970). Soldat (1962) published the data relating to dispersion studies and measurements of radioactivity made on the Columbia River in the vicinity of the Hanford Site from 1946 through early 1961. Results of these studies have indicated that contaminant plumes entering the river along the shoreline tend to remain near the shore for several miles downstream of the discharge point. Backman (1962) concluded that effluents discharged from the 300 Area were nearly completely mixed by the time they reached the Pasco water treatment pumping station, approximately 16 miles downstream. Contaminants discharged in the 300 Areas were not expected to be completely mixed 5 miles downstream at the City of Richland water intake (Richland Pumphouse). Based on the above studies, the contaminants entering the river via the 200 Area ground-water plume near the 300 Area are not likely to be completely mixed at the Richland Pumphouse, located approximately 6 miles downstream of the most southerly discharge point of the contaminated 200 Area ground water.

Following the years of peak plutonium production, the reactors began shutting down and the quantity of radionuclides discharged to the river decreased significantly. The shutdown of the last single-pass-cooling reactor resulted in the virtual elimination of major discharges to the river. Consequently, river monitoring activities were greatly streamlined and crosssectional surveys were all but eliminated. With the potential risk of any significant dose to the public from activities associated with the river vastiy diminished, the need for extensive monitoring was reduced. Emphasis was placed on obtaining an optimum type and amount of data for the evaluation of the contribution of Hanford effluents to the radiation dose received by persons living in the vicinity and using Columbia River water.

Ultimately, only a few fixed sample locations remained of the Columbia River monitoring network. The primary locations were chosen to represent 
background conditions upstream of site operations (Priest Rapids Dam) and establish an upper estimate of the amount of radioactivity in the water supply of any population using Columbia River water by sampling at the first downstream point of withdrawal (Richland Pumphouse). Samples of Columbia River water were also collected periodically at other locations in conjunction with special studies. These locations continue to serve as the primary sampling locations on the Columbia River for the SESP.

Over the years since the shutdown of the original production reactors, radionuclide concentrations in the Columbia River have remained extremely low and the potential dose to the public is of little or no consequence with respect to health effects or applicable standards. However, a number of factors have changed, warranting further cross-sectional sampling efforts. Since the shutdown of the original eight reactors, the primary source of radioactivity entering the river has changed from direct effiuent discharges to the seepage of contaminated ground water from beneath the Hanford Site into the river. Consequently, the location along the Hanford Reach at which the contamination is entering the river has changed. With the changes in operations and pathways to the river, the specific radionuclides of interest have changed as well. Guidelines for environmental surveillance at DOE facilities recommend cross-sectional sampling of the river at existing monitoring stations whenever a significant change occurs in either the types or quantities of radionuclides being released (DOE 1991).

Routine Columbia River monitoring data during recent years have shown a general decrease in radionuclide concentrations (Woodruff et al. 1992). Figure 3 illustrates the concentrations of tritium in Columbia River water at Priest Rapids Dam and the Richland Pumphouse during the past 10 years. This downward trend, evident both upstream and downstream of Hanford, is not consistent at both locations. The differences between tritium concentrations observed at the Richland Pumphouse and Priest Rapids Dam have been variable, apparently increasing slightly in recent years (Figure 4 ). This could be a result of lower river flows during recent years (i.e., less dilution) or may reflect a nonuniform distribution of tritium across the river as a result of the location of ground-water discharges relative to the sample location. 


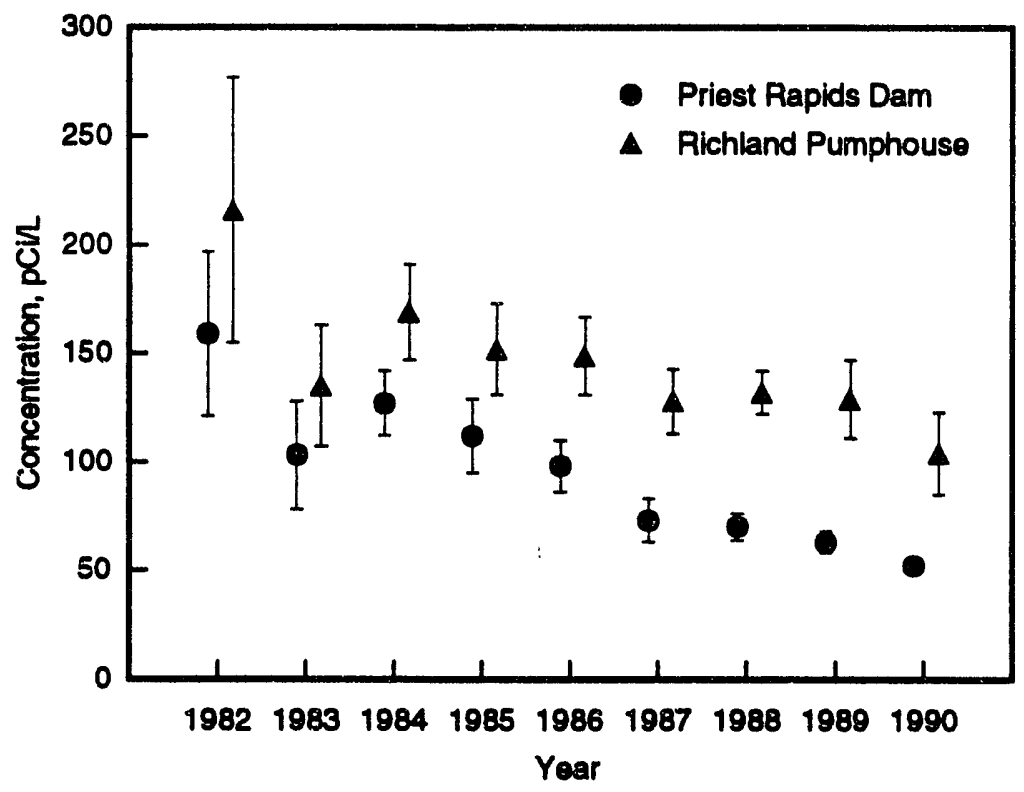

S9200083.8

EIGURE 3. Tritium Concentrations in Columbia River Water at Priest Rapids Dam and the Richland Pumphouse, 1982 Through 1990

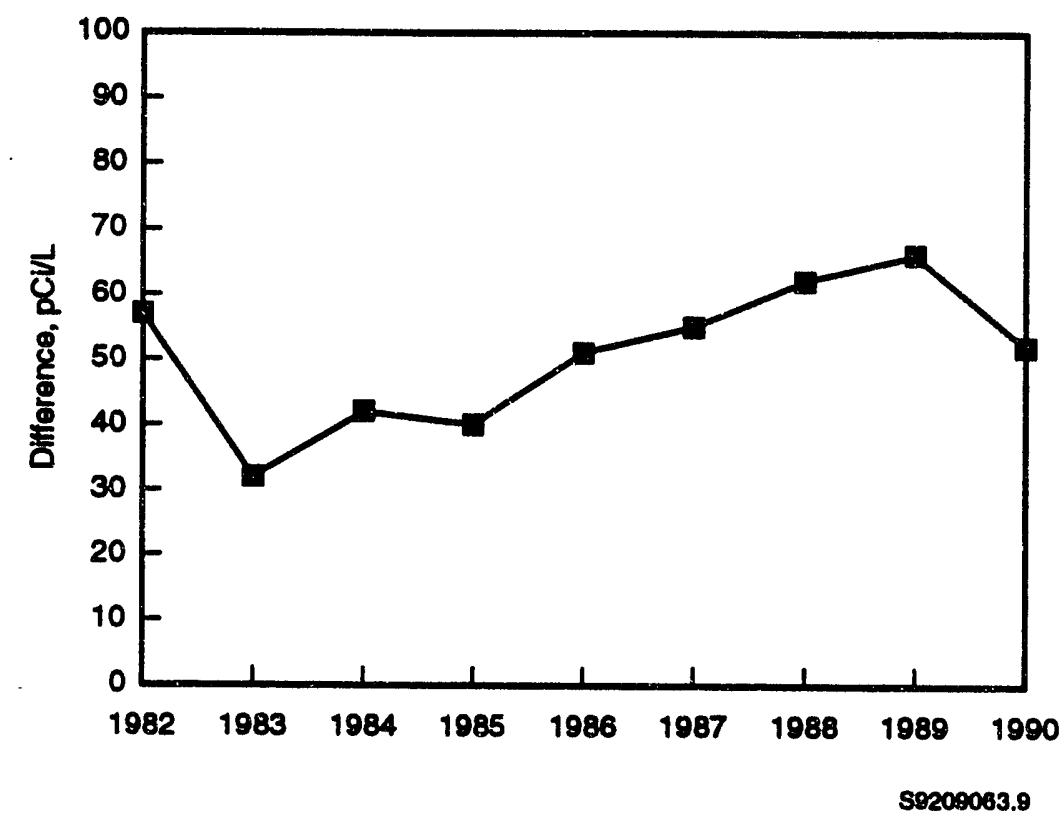

FIGURE 4. Difference in Annual Average Tritium Concentrations at Priest Rapids Dam and the Richland Pumphouse, 1982 Through 1990 
Other factors have also contributed to the recent emphasis on Columbia River monitoring activities. Ground-water modeling activities have come under increased scrutiny recently, and the adequacy of existing models have been challenged, primarily with respect to travel times to the river and estimates of the volume of ground water entering the river (Buske and Josephson 1986; USGS 1987). Public interests and concerns have increased significantly in response to proposed operations at Hanford. As a result, outside investigations of the quality of the Columbia River water, the ground water/river inter-relationship, and the impact from Hanford operations were initiated (Buske and Josephson 1987), often using data from the existing program in a manner for which they were not designed or intended.

The existing routine Columbia River monitoring program was not designed for investigations of this type. Supplemental monitoring activities, perhaps with different systems and techniques, providing more detailed radionuclide and/or site-specific data on the river may be required for considerations such as mass balance calculations and improved ground-water flow model development and verification (Lettenmaier 1988).

Cross-sectional sampling of the Columbia River at a transect near the Richland Pumphouse is also warranted to determine the distribution of radionuclides in the river at this location under the present contaminant conditions. The relationship between the concentrations observed at the Richland Pumphouse and those in the river itself must be understood to accurately evaluate the impacts of Hanford on the quality of the Columbia River water and in the assessment of radiation dose potentially received by those living near and using the Columbia River. In addition, cross-sectional sampling at a transect located at the Richland Pumphouse fulfills the requirements and recommendations set forth in applicable DOE environmental monitoring guidance (DOE 1991). 


\section{STUDY DESCRIPTION}

\section{OBJECTIVE}

The objective of this study was to determine the distribution of radionuclides, primarily tritium, within the river at the routine Columbia River monitoring station located at the City of Richland drinking water intake (Richland Pumphouse). In addition, the investigation was designed to evaluate the relationship between the average tritium concentrations in the river and those measured in samples collected using the SESP water sampling system operated at the Richland Pumphouse.

\section{FIELD STUDY}

Cross-sectional sampling was conducted at transect locations at or near the Richland Pumphouse river monitoring location during the summers of 1987 and 1988. Samples were collected at various stations along the cross section to determine the distribution of tritium across the river at this location (Figure 5). Samples were also collected from various depths to evaluate the vertical distribution of tritium at stations along the cross section during one sampling event. Depth and velocity were measured at each station to be used to calculate the average tritium concentration in the river. Various water quality measurements were performed in the field during each sampling traverse as we11. In addition, the water level of the river was recorded periodically throughout the sampling period at the Richland Pumphouse. River flows, as recorded by the United States Geological Survey (USGS) at Priest Rapids Dam, were also obtained in conjunction with this study.

Simultaneously, samples were collected at the Richland Pumphouse directly from the routine sampling system. These samples provide a direct comparison of tritium levels measured by the routine SESP water sampling system with those in samples collected from various points across the river. In addition, the average tritium concentrations in water from the Richland Pumphouse sampling system were compared with the average tritium 
Sample Point (0.6 depth)

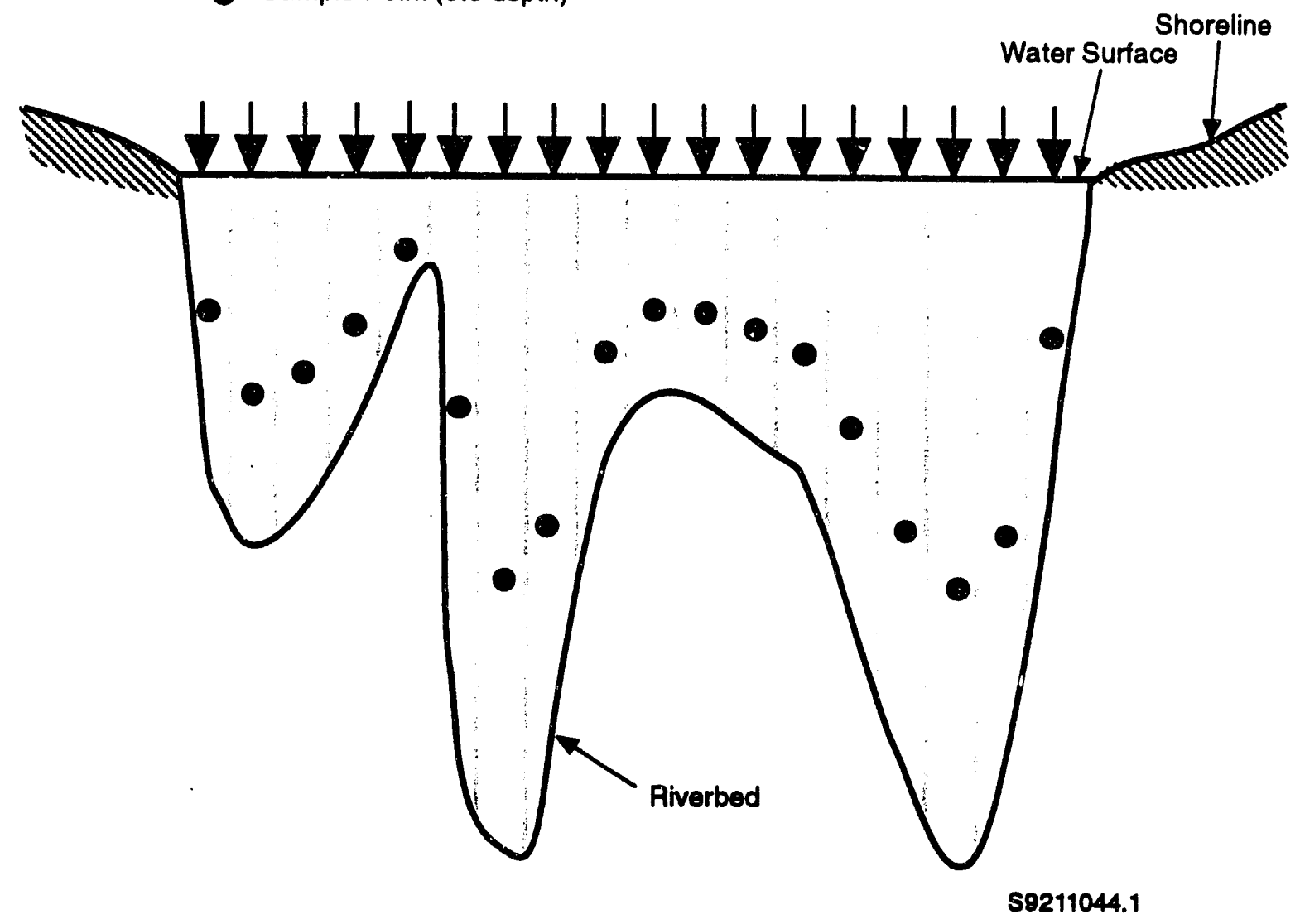

FIGURE 5. Schematic of Cross Section Sampling Plan

concentrations in the river. Sampling at the Richland Pumphouse also provided information relative to the variability in tritium concentrations over time at a single location.

Quality control samples were collected periodically throughout the study. These included duplicate samples collected from the river at various stations as well as from the Richland Pumphouse sampling system. This information provided a basis for evaluating the analytical variability and was an important consideration during the interpretation of the sample results. 


\section{Constituents of Interest}

Several radionuclides are known to be entering the river through the seepage of contaminated ground water, including ${ }^{3} \mathrm{H},{ }^{90} \mathrm{Sr},{ }^{99} \mathrm{Tc},{ }^{125} \mathrm{Sb}$, and ${ }^{129} \mathrm{I}$ (Dirkes 1990). Strontium-90 and ${ }^{125} \mathrm{Sb}$ were entering the river at the time of this investigation at the $\mathrm{N}$ Springs, approximately 40 miles upstream of the Richland Pumphouse. Sased on past contaminant dispersion studies, contaminants released at $\mathbf{N}$ Springs would be well mixed within the river by the time they reached Richland (Backman 1962; Soldat 1962). Antimony-125 was not measurable in river water during 1987 or 1988 (Jaquish and Mitchell 1988; Jaquish and Bryce 1989). Strontium-90, while measurable in river water using large-volume samples and special analytical techniques, was at very low concentrations and the leve? $s$ of ${ }^{90} \mathrm{Sr}$ upstream and downstream of Hanford were essentialiy the same (Jaquish and Mitchell 1988). As such, ${ }^{90} \mathrm{Sr}$ and ${ }^{125} \mathrm{Sb}$ were not appropriate choices in evaluating the distribution of radionuclides in the Columbia River at the Richland Pumphous..

Tritium $\left({ }^{3} \mathrm{H}\right),{ }^{99} \mathrm{TC}$, and ${ }^{129} \mathrm{I}$ were known to be present in the contaminated ground-water plume emanating from the 200 Areas. The southern edge of this plume has been approaciling the 300 Area during recent years as discussed earli $i$ (see BACKGROUND INFORMATION). Technetium-99 was not analyzed routinely in river water during 1987 and 1988 (Jaquish and Mitchell 1988) and therefore was not suitable for this study. Iodine-129, while measurable in the river using special sample collection and analytical techniques, and documented to be higher at the Richland Pumphisse than at Priest Rapids Dam (Jaquish and Bryce 1989; Jaquish and Mitchell 1988), was not considered for this study because of the high cost of analysis.

Therefore, tritium was selected as the primary radionuclide of concern for the purposes of this investigation. A number of factors played a part in the seiection of ${ }^{3} \mathrm{H}$ as the primary component in this study, including:

- Tritium is a major constituent in the ground water entering the river along the Hanford Reach as a result of past operations. Tritium is knovin to be a primary constituent in the ground-water plume nearing the routine river sampling location (Evans et a1. 1992).

- There is a reported difference in the tritium concentrations observed at Priest Rapids Dam and the Richland Pumphouse, indicating a contri-bution 
from Hanford (Jaquish and Bryce 1989; Jaquish and Bryce 1990; Jaquish and Mitchell 1988; Woodruff et a1. 1991; Woodruff et a1. 1992).

- Tritium is a major contributor to the offsite dose through the surfacewater pathway (Woodruff et al. 1992).

- Analytical techniques, using special procedures, are sensitive enough to detect tritium at the levels present in the river, allowing meaningful comparisons of the data from the river and the routine sampling system.

- The costs associated with tritium analysis are not prohibitive.

- Finally, significant public and political interest and concern in the source, quantity, and impact of tritium entering the river has been expressed (Buske and Josephson 1986; Buske and Josephson 1987; USGS 1987).

Selected samples were occasionally analyzed for certain radiological constituents in addition to tritium. These included total alpha, total beta, strontium-90, and isotopic uranium. In addition, $\mathrm{pH}$ and conductivity were measured in the field at each cross-section station. Results of these analyses and field measurements are presented in Appendix $B$.

\section{River Flow}

In 1987, the cross-sectional sampling was scheduled to be performed three times during late summer. This time period was selected because it is generally associated with relatively low river flow rates. Low flow rates, below the recent annual average discharges (100,000 to $120,000 \mathrm{cfs})$ were desired to minimize the dilution of the contaminants in the river and maximize the contribution from Hanford to the extent possible. Efforts to establish an upper estimate of the difference (bias) in tritium concentrations observed at the routine sampling location and the average concentrations in the river at this location were made in this fashion.

Three sampling traverses were also scheduled during 1988. However, sampling was scheduled to coincide with a wide range of river discharges, a significant change from 1987. Samples were scheduied during periods of high flow in the spring, under average river flow conditions during the summer, and during low flows typically experienced in the fall. It was anticipated that this pattern would provide data for evaluating the relationship between tritium 
concentrations in samples from the routine water sampling system and the average river concentration under varying flow conditions.

\section{Transect Locations}

The locations of the transects, which were at or near the City of Richland water intake (Richland Pumphouse) during 1987 and 1988, are shown in Figure 6. During 1987, the transect was located approximately 2000 feet upstream of the Richland Pumphouse structure. This location was selected to avoid the island directly east of the routine sampling location, allowing a continuous uninterrupted traverse of the river. This location is also of historical significance because cross-sectional sampling was conducted at this point during the years of reactor operations (Backman 1962). Historically, this site is identified as the Richland Ferry Traverse. This location does not, however, allow for the dispersion of the contaminants that would take place over the remaining 2000 feet to the Richland Pumphouse.

The 1987 transect location was between two islands where the river channet crosses from the east to the west side of the river. This crossing influences the flow regime and may influence the dispersion of tritium across the river. Ideally, cross-sectional sampling should be conducted where the flow channel is relative straight. Consequently, a second transect was located directly at the Richland Pumphouse during the 1988 sampling activities. Performing the cross-sectional sampling at the location of the routine monitoring station reflects actual field conditions and allows for a direct comparison of the results obtained during the study.

\section{Number of Sampling Traverses}

The number of sampling traverses conducted each year was limited by the amount of funding available for the study. Costs associated with sample collection and, more significantly, sample analysis determined the number of sample cross sections that could be performed each year. Sample collection costs depended on the number of stations along the cross section, the number of depths sampled at each station, and the number of samples collected at each depth. Costs associated with the analysis included not only the number of 


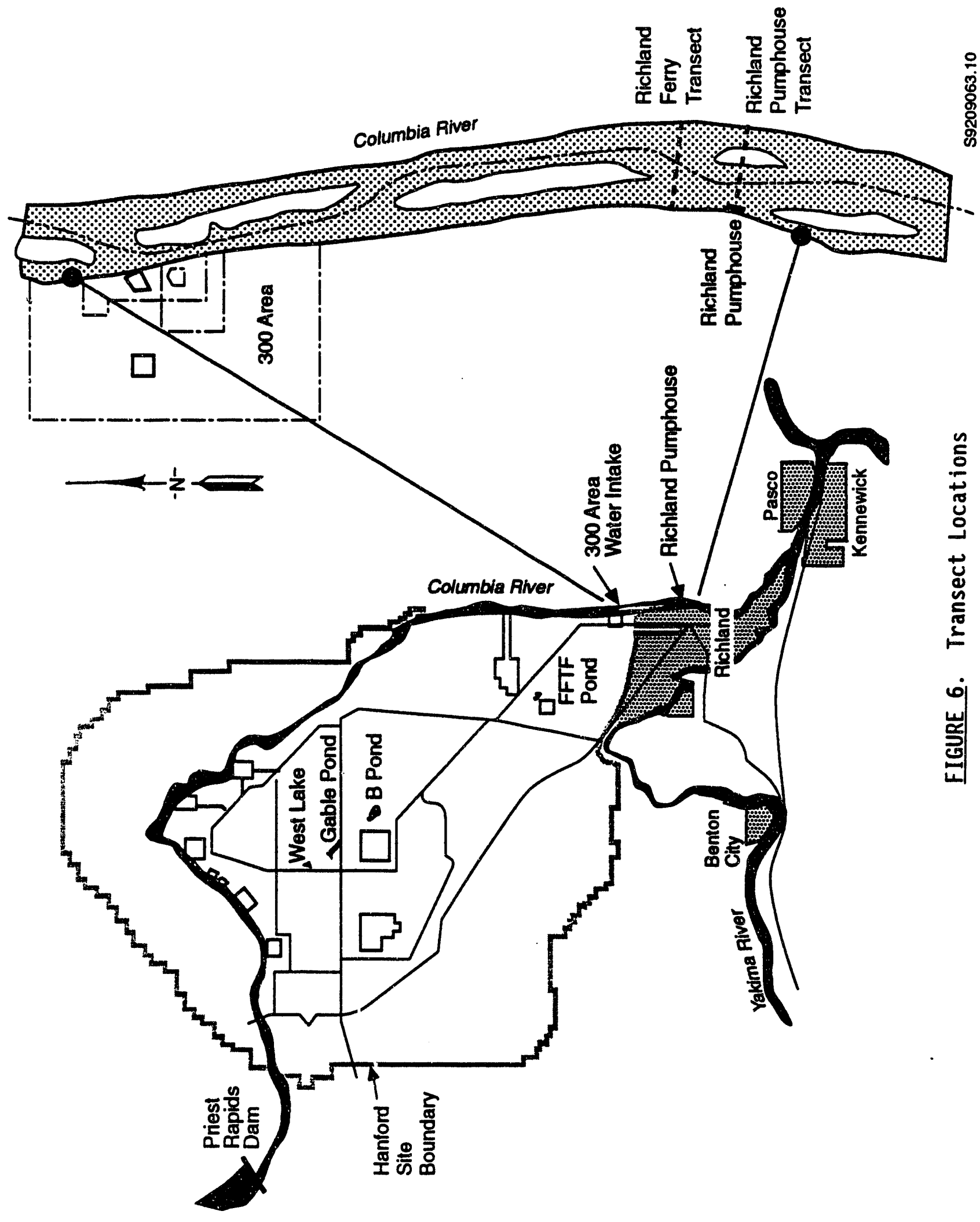


samples, but the sensitivity requirements of the study as we11, which mandated the analytical technique used. Efforts were made to balance the various needs throughout the study and meet the study objectives. As a result, three sampling traverses were made during each year.

\section{Number of Stations Along the Transect}

Guidance is available relative to the number of stations needed along a transect to obtain representative results. According to DOE (1991), samples should be collected from more than one depth and at a minimum of four to six stations equidistant across the stream flow along each traverse. Ideally, each sample should not represent greater than $10 \%$ of the total stream flow (DOE 1991). Standard methods for the determination of open channel flow also specify that each section (station) represent, at a minimum, no more that $10 \%$ of the total flow and recommend that no single measurement represent more than $5 \%$ of the total flow (ASTM 1988).

Based on this guidance, 18 stations were established at approximately 50-meter intervals across the cross section during 1987. During 1988, with the presence of the island at the transect location, 10 stations were established within each channel, resulting in a total of 20 stations along the crass section.

\section{Number of Sample Depths per Station}

Past studies have indicated that contaminants mix vertically quite rapidly in the Columbia River (Backman 1962; Haney 1957). It was anticipated, based on the past studies and the proximity of the source to the sample location, that the tritium would be mixed vertically at the Richland Pumphouse sample location. However, determining the vertical distribution of tritium in the water column at the Richland Pumphouse during this investigation would verify this past finding. To this end, samples were collected at multiple depths $(0.2,0.6$, and 0.8 times the river depth) at selected stations during the first sampling traverse conducted during 1987. Samples were collected from a single depth ( 0.6 times the river depth) during the remaining traverses 
conducted during 1987 and all of the 1988 sampling. The sample depths were selected to coincide with the depths at which the velocity was to be measured.

Equipment

A wide variety of equipment was required to conduct the cross-sectional sampling. This discussion refers primarily to the sampling vessel and the accessories that were used during the course of the study. The instruments and equipment used directly in the performance of field measurements or the collection of the water samples are described separately in appropriate sections of the report.

\section{Sampling Vessel}

The sample vessel used throughout the course of this investigation was an 18-foot Monarch boat equipped with dual 75-horsepower outboard motors. The craft was equipped with various auxiliary equipment as shown in figure 7 . The necessary equipment included a bow-mounted electric winch for anchor deployment, a stern-mounted davit with battery-operated winch with steel cable and wire-line depressor for vertical positioning of the sampling and velocity measurement equipment, and an Aqua Probe fathometer for depth measurements and bathymetric surveys. Communications were facilitated with portable line-ofsight short-wave radios.

Horizontal and Vertical Position Control

The control of the horizontal (across the river) and vertical (upriver/ downriver) positioning of the sampling vessel was maintained through the use of a Topcon Geodetic Total Station and Leitz Electronic Total Station electronic distance meter (EOM) in 1987 and 1988, respectively. The EDM was positioned and operated from the Benton County shoreline at the location of the transect. The EDM system target was positioned on the sampling vessel to accurately measure the distance to the sample location.

The distances to the desired cross-section stations were calculated at the time of sampling using the measured width of the river. Initial placement 


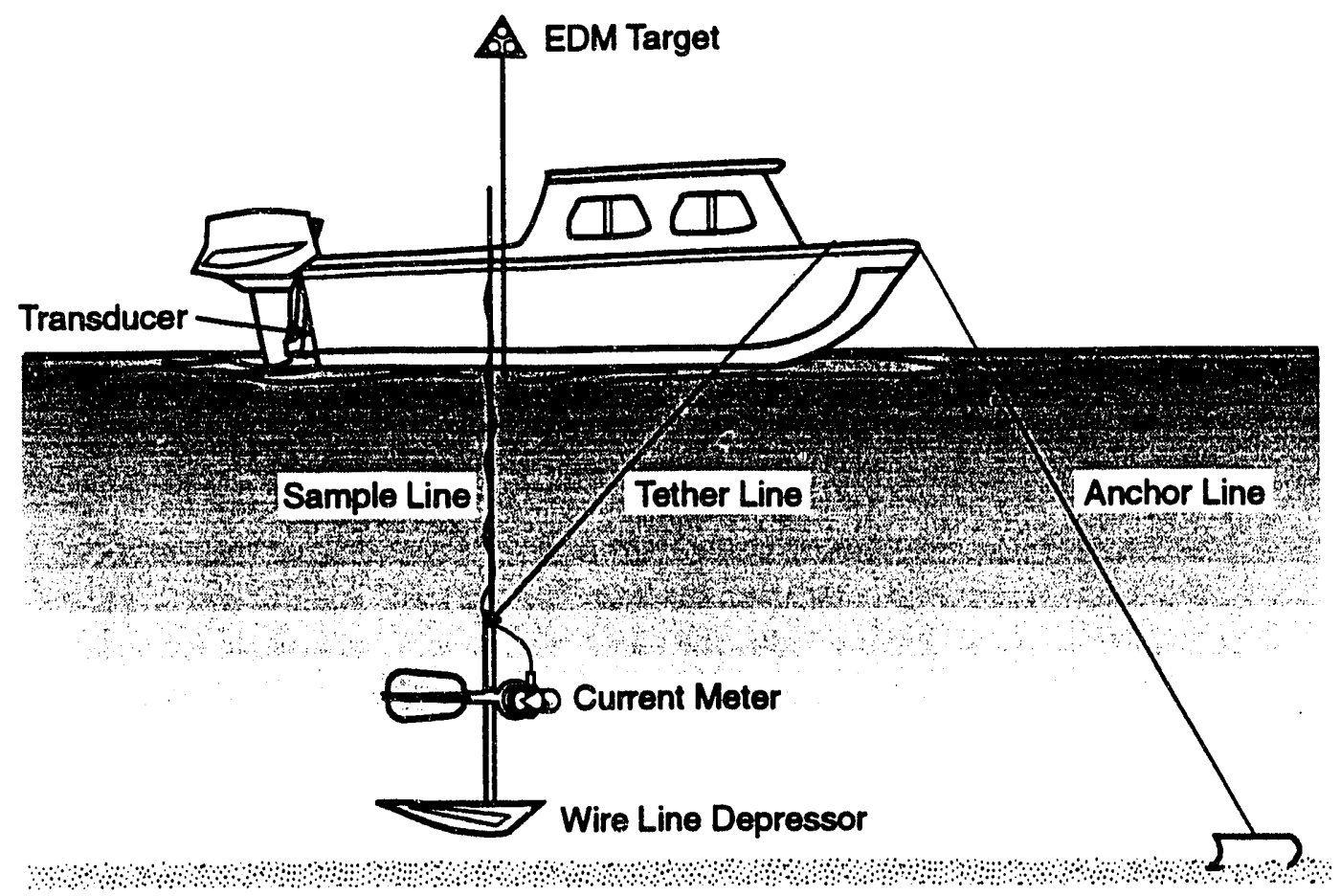

S9209063.6

EIGURE 7. Sample Vessel and Equipment

of the vessel at the calculated positions was estimated by the vessel operator. Distance measurements taken at this position indicated adjustments as necessary. Once an acceptable horizontal position was established, vertical positioning was initiated.

Vertical, upriver or downriver, control was established by verbal direction of the onshore EDM operator. The vessel was moved several meters directly upstream of the desired horizontal position and the anchor dropped. Once stabilized, the vessel was gradually moved downstream on the anchor line as directed by the EDM operator. In this manner the vessel was positioned directly on the desired transect.

Once positioned, the final sample station location was determined and recorded using the EDM. The final measurements provided both the distance from the EDM to the vessel and the position (angle in degrees) of the craft above or below the true transect ( 0 degrees). 


\section{Depth Control}

The depth of the river was measured and recorded at each cross-section station before sampling. Once the depth of the river at the sample location was determined, the desired sample collection and/or velocity measurement depths were calculated. The depth of the sample collection equipment and current meter was controlled using a meter stick fastened to the davit from which the equipment was being lowered using an electric winch with steel cable. The equipment was lowered at known increments to the desired depth. A tether line, used in conjunction with the wire-line depressor, was needed in some cases to ensure the proper positioning of the sample intake and the current meter in the water column (Figure 7 ).

\section{Field Measurements}

Specific conductance and $\mathrm{pH}$ measurements were performed in the field at stations along the cross section. These measurements are performed routinely by the sampling personnel as part of ongoing environmental monitoring programs using approved procedures (PNL 1989). In addition to these water quality related measurements, the water depth and current velocity were determined at each cross-section station using the manufacturers' recommended operating procedures. The methods used in conducting these field tests are described briefly below. Results of field measurements and other limited radionuclide analyses are included in Appendix B.

\section{pH}

The $\mathrm{pH}$ of the river water was determined at each sample location at a depth equal to 0.6 times the river depth, consistent with current velocity measurements and sample collection. The $\mathrm{pH}$ instruments used were calibrated before use each day during the investigation in accordance with standard environmental surveillance procedures (PNL 1989). Calibration standards used were in the range typically observed in Columbia River water.

\section{Specific Conductance}

The conductivity of the river water was also measured at each station. Similar to other field measurements, conductivity was measured on water collected from a depth 0.6 times the river depth. As in the case of $\mathrm{pH}$, the 
instruments used to measure conductivity were calibrated according to estab7 ished procedures before use each day (PNL 1989). Calibration consisted of both internal standards, which served primarily as a battery check, and external standard solutions. The standard solutions used in the routine calibrations were in the range typically observed in Columbia River water.

\section{Current Velocity}

Velocity was measured using a cup-type vertical-axis current meter according to standard procedures for the measurement of velocity in open channels (ASTM 1988). Specifically, a Teledyne/Gurley Model 675 current meter with a Model 700 digital flow velocity indicator was used during the course of this investigation.

Current velocity was measured at multiple depths at each station along the cross section. Figure 8 provides a detailed drawing of the current meter used during this investigation. Past experience on the Hanford Reach of the Columbia River upstream of the transect location had shown the vertical velocity profiles to be quite variable. It was determined that velocity measurements taken at 10 depths best estimated the average velocity at the sample station. During 1987, velocity was measured at one-tenth depth intervals or at 10 depths at each station. Four velocity readings were obtained over 15-second intervals from each depth. The measurements were then averaged at each depth to provide vertical velocity profiles at each station. Vertical velocities were then averaged over the entire water column to determine the average velocity for each section of the river.

During 1988, following evaluation of the data obtained during the 1987 field activities (see RESULTS AND DISCUSSION), it was determined that the twopoint method ( 2 depths; 0.2 and 0.8 depth below the water surface) was adequate to estimate the average section velocity (ASTM 1988). To minimize excessive measurement variability, eight velocity readings, over timed intervals, were taken at each of the two depths. Average velocities for each section of the river along the transect were then determined as described above. 


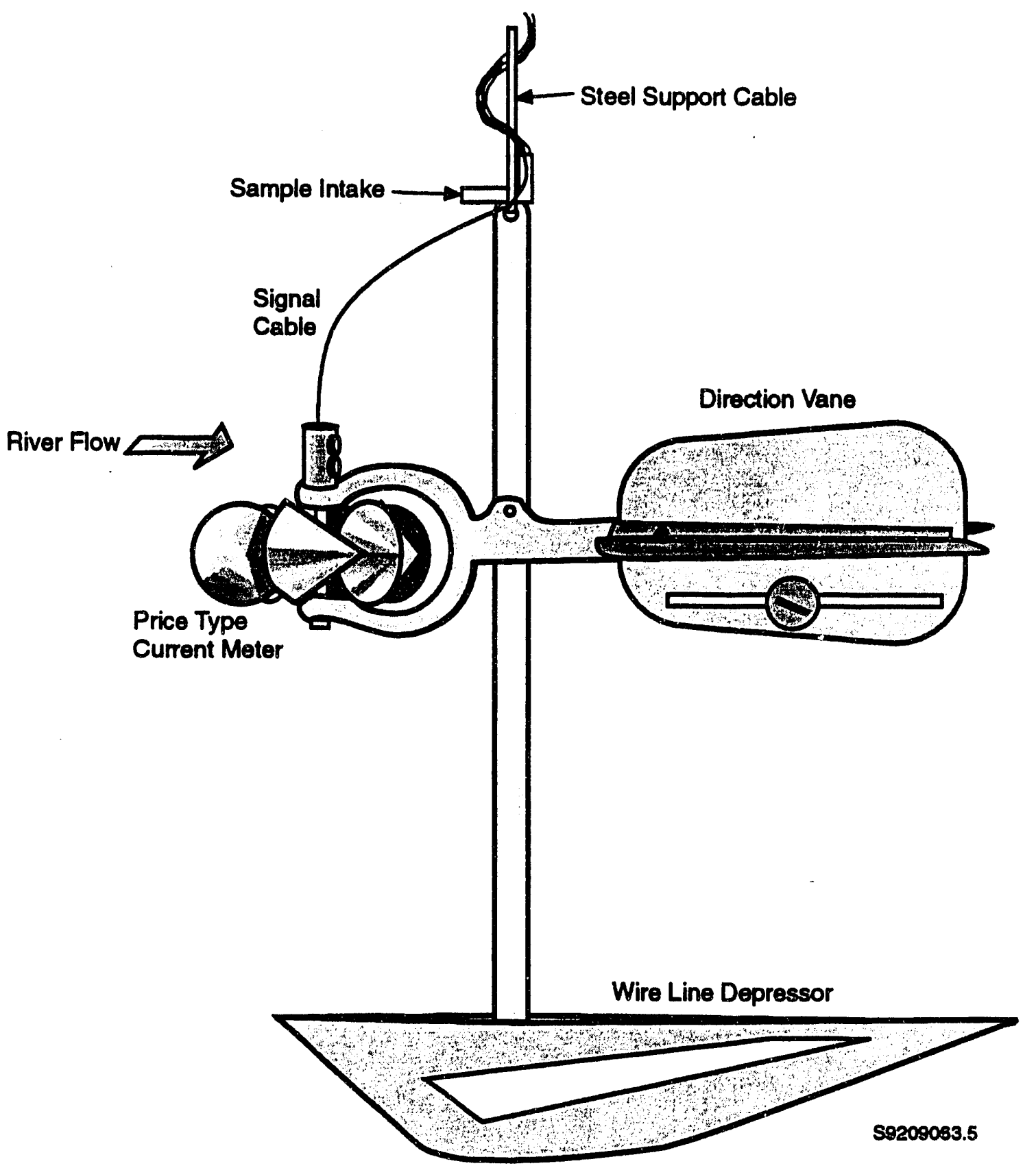

EIGURE 8. Sample Intake and Current Meter Configuration 


\section{Water Depth}

River depth measurements made at each sampling station along the cross section and during bathymetric surveys were made using an Aqua Probe fathometer. The unit was calibrated using a steel calibration plate lowered on a graduated chain beneath the fathometer transducer. The calibration plate was lowered at known intervals over the range of depths to be surveyed. A typical calibration fathometer chart is shown in Figure 9.

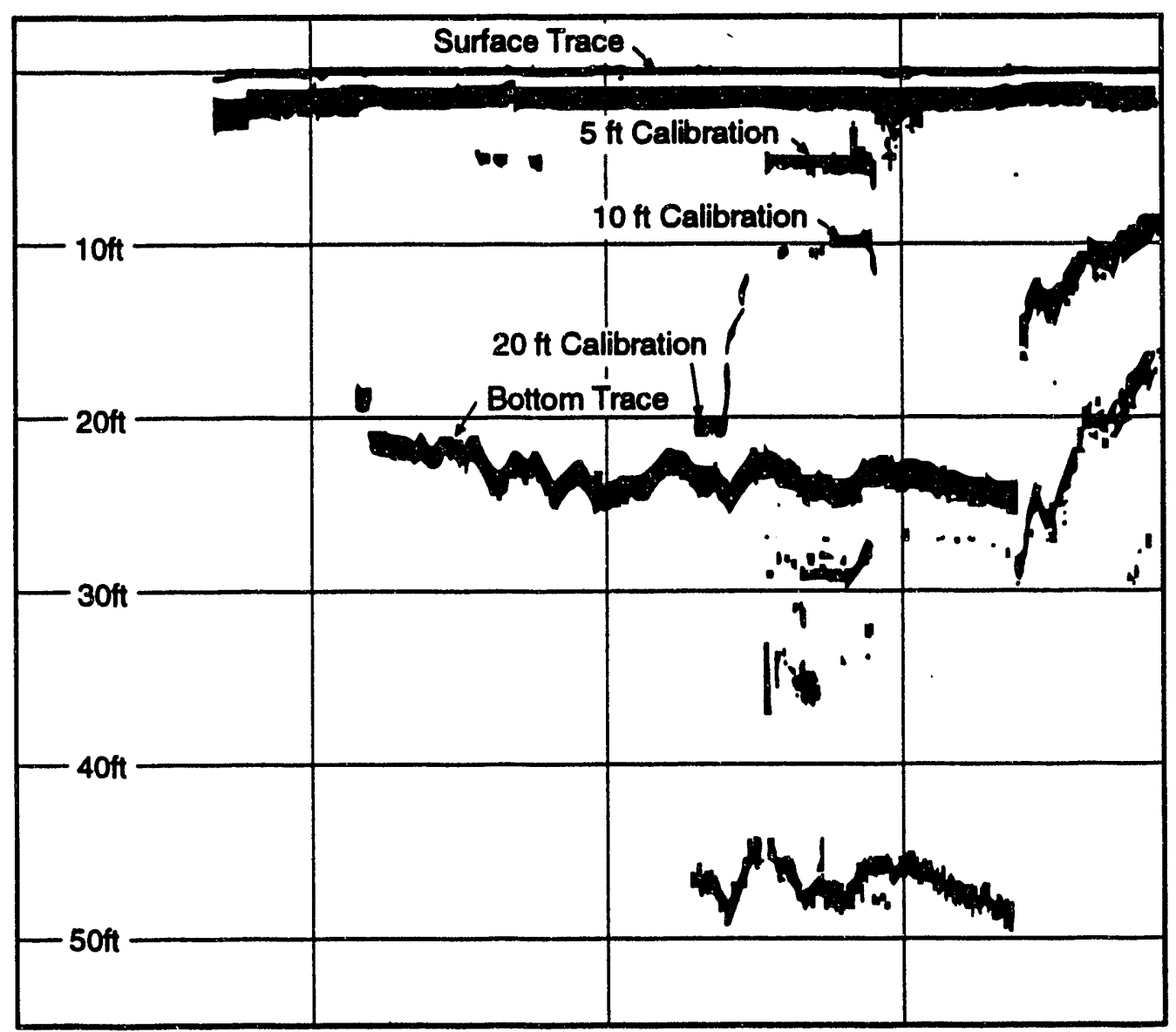

S9209063.4

EIGURE 9. Typical Fathometer Calibration Chart 
Bathymetric surveys of the river at the location of the transect were conducted before each days sampling activities. The river was traversed at a constant velocity, within vessel operating limits, along the cross section. Vertical, upriver/downriver, control was maintained during the traverse using reference points on the opposite bank and through radio contact with the EDM operator located on the shoreline.

The depth of the river was determined at each cross-section station to determine the appropriate depths for velocity measurements and sample collection. In addition to the depth measurements made at each station along the transect, water level measurements, providing relative water surface changes, were recorded from the Richland Pumphouse. Staff gage readings were made at the time that each sample was collected from the Richland Pumphouse. Such measurements provided information relative to the water level of the river (rising or falling hydrograph) during the course of the cross-sectional sampling activities.

\section{Sample Collection}

A battery-operated peristaltic pump (Figure 10) was used to collect the water samples from the desired depth and deliver them to the sample container. The sample inlet depth was controlled by lowering of a wire-line depressor at known increments as previously discussed. The sample lines were purged for several minutes before sample collection to ensure that the water from the desired depth was being collected and to avoid potential cross-contamination of the samples between depths and/or cross-section stations.

Samples were collected in 125-milliliter bottles in accordance with accepted sample handling protocols. Each sample was identified by a unique sample number established through the SESP database steward. Data received from the laboratory was identified by this sample number. Sample collection and chain-of-custody were documented on trip sheets or trip logs used routinely in the routine environmental surveillance program. Samples were delivered to the appropriate laboratory as soon as possible following sample collection, within sample transport/storage restrictions. 


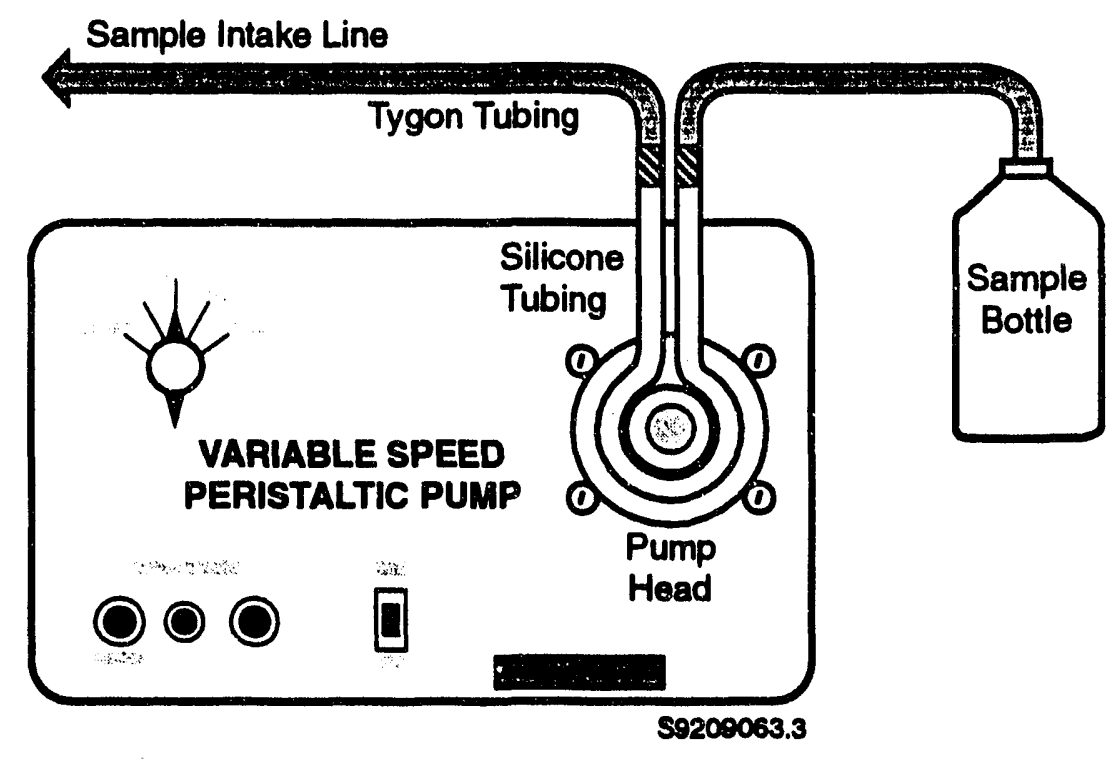

EIGURE 10. Water Sampling System Schematic

\section{Sample Analysis}

Tritium was selected as the primary radionuclide of concern as discussed earlier in the report. It was determined that the analytical method used for determination of tritium concentrations in routine river water samples was inadequate for the purposes of this study. The electrolytic enrichment method, as used on the routine water samples, was not sensitive enough to determine whether or not significant differences existed between the average river and Richland Pumphouse concentrations. An electrolytic enrichment procedure with low-level counting was used during both years of the study to obtain results that would allow for the desired data evaluation. Following preliminary analysis of the 1987 sample results it was determined that further enhancement of the methods was needed. Improvements in the precision of the analytical method used in 1988, which made differences in the concentrations observed at the Richland Pumphouse and in the river along the transect readily apparent, were specified in the analytical work request.

\section{Data Analysis}

The current velocity measurements made during the transect sampling activities were used in determining the river discharge according to commonly accepted methods (ASTM 1988). Using this method the river is divided into 
sections for which a discharge is calculated using the velocity as measured and the area of the section as determined by the river depth and the distance from the previous station. The total river discharge, or flow, is the sum of all the sectional discharges for each traverse.

The sample results were plotted with distance from the Benton County shoreline to determine whether or not a tritium concentration gradient exists at the Richland Pumphouse. Tritium concentrations in river water along cross sections and in the Richland Pumphouse monitoring system in concurrent samples were compared to determine the extent of any differences. The tritium concentrations determined for each river section were also used in conjunction with the sectional discharges to calculate the average tritium concentration in the river. Ultimately, the average river tritium concentration was compared with the average tritium concentration observed at the Richland Pumphouse during the course of the sampling traverse, providing a measure of the bias in the routine river monitoring samples resulting from the location of the sample system intake.

\section{QUALITY CONTROL}

All samples were collected and handled according to approved sample collection procedures. Adhesive labels, placed on the sample bottles, were completed in ink and covered with clear plastic tape. Chain-of-custody, which was maintained throughout the sample collection and transport process, was documented on Environmental Surveillance Trip Logs, with custodian transfer and sign-off upon relinquishing the samples to the laboratory. Samples were delivered to the laboratory as soon after collection as practical, well within recommended sample storage/transport time limitations for the desired analyses.

Field instruments were calibrated or checked against appropriate standards according to manufacturers' recommendations and established procedures before each day of sampling (PNL 1989). Field measurements were documented within field records and maintained in the special study files.

Duplicate samples were collected and submitted throughout the course of the study. Duplicates made up approximately $10 \%$ of the total number of 
samples submitted for analysis. Analytical requirements, discussed previously, were well defined through the purchase requisition specifications. l.aboratory quality control requirements, specified in the analytical order, included weekly bacisground checks, process blanks, reagent blanks, and weekly calibration runs, using samples prepared and traceable to the National Bureau of Standards. Duplicate sample results are presented in Appendix $C$. 


\section{RESULTS AND DISCUSSION}

Samples of Columbia River water were collected along cross sections established at transect locations near the Richland Pumphouse and from the routine water sampling system at the Richland Pumphouse during 1987 and 1988. Samples were collected simultaneously from the two locations to allow for meaningful comparisons. In addition, samples were collected at various depths during 1987 to provide information relative to the vertical distribution of contaminant concentrations in the river at this location.

The cross sections were sampled on three separate occasions each year. The cross-sectional sampling was conducted on August 27, August 31, and September 10, 1987. During 1988, sampling was performed on June. 23, August 5, and September 29. Results of field sampling activities are discussed in the subsequent sections.

\section{RIVER FLOW}

Daily average river flows observed at Prie: Rapids Dam are provided in Tables A.1 through A.4, Appendix A, for the time periods directly before, during and after the respective cross-section sampling. Table A.1 provides the daily average flows for the time period August 20 through September 12, 1987, which encompasses all three days of sampling performed during 1987. Tables A.2, A.3, and A.4 provide similar flow data for the three cross sections sampled during 1988. In each case, the daily average flows are provided for the 0 days preceding and 5 days following the sample date to provide an indication of the flow patterns during the investigation. It is evident in these tables that daily averages varied significantly from day to day, rendering direct comparisons of river flow with impacts from ground-water seepage difficult and adding to the complexity of this relationship.

As anticipated, flow rates during the 1987 field activities were generally below the 1987 annual average flow of 101,000 cubic feet per second, cfs (Figure 11). Daily average discharges for August 27, August 31, and September 10, 1987, were $79,300 \mathrm{cfs}, 87,700 \mathrm{c} \mathrm{s}$, and $68,100 \mathrm{cfs}$, respectively. 


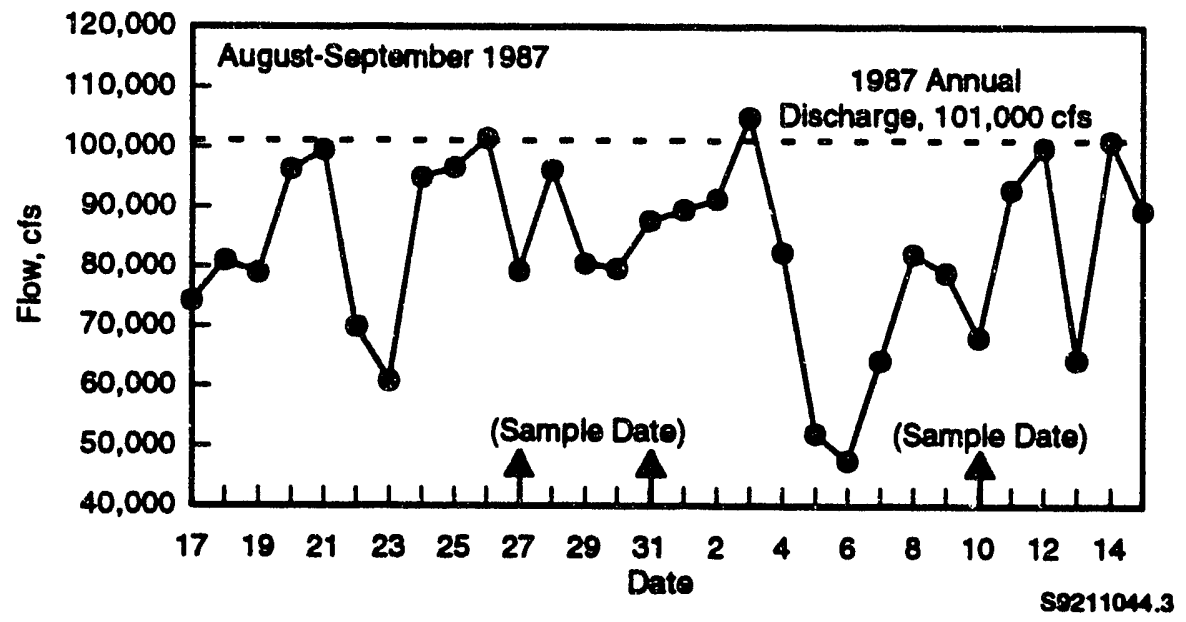

FIGURE 11. Daily Average Discharge, Columbia River at Priest Rapids Dam, August 17, 1987 Through September 15, 1987

The lowest daily average flow recorded during 1987 was 46,000 cfs. The probable influence of the flow of contaminated ground water into the river on the contaminant concentrations in the river was therefore increased relative to average river flow conditions but not as high as it may have been during lower flows.

During 1988, the daily average flows during the sampling activities varied significantly with respect to the annual average flow of $100,000 \mathrm{cfs}$ (Figure 12). The discharge during June is typically the highest during the year as a result of the spring run-off. The daily average flow was 127,000 cfs on June 23, 1988, the day of the first sampling traverse conducted during 1988. The second traverse was conducted on August 5, 1988, with a daily average flow of 93,400 cfs, similar to the annual average flow. The final sampling traverse, September 29, 1988, was conducted under lower flow conditions, $79,600 \mathrm{cfs}$. While these flows do not represent the minimum, average, and maximum observed during the year $(42,000,100,000$, and $160,000 \mathrm{cfs}$, respectively), they do represent flow conditions above, near, and below the annual average during 1988.

A.unual average flows for the years 1980 through 1990 are provided in Table A.5, Appendix A. Note that the annual averages during 1987 and 1988 

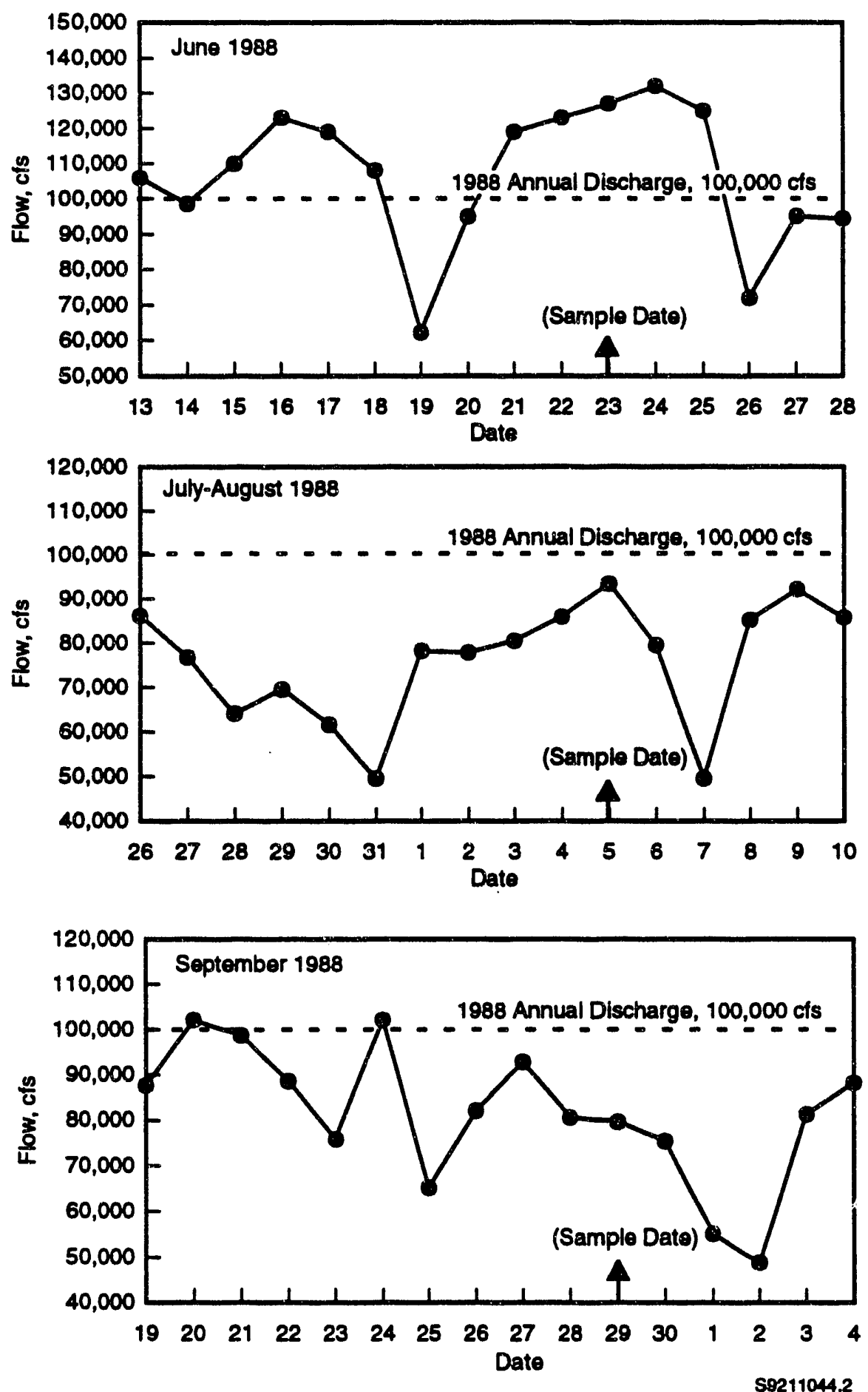

FIGURE 12. Daily Average Discharge, Columbia River at Priest Rapids Dam, June 1988 Through October 1988 
were lower than those generally recorded. The long-term annual average discharge, based on 68 years of record, is reported to be approximately $120,000 \mathrm{cfs}$, well above those seen during the years of this investigation (McGavock et al. 1987). As a result, the impacts observed during this investigation may be elevated when compared to those that would be evident during a more normai water year. That is, in an "average" year the river flows are higher, thereby increasing the dilution capacity and reducing the impact of the relatively consistent ground-water flows into the river. This would be influenced, however, by the range of flows during the year and the amount of time the flows were actually above or below the average. Further study of this influence may be warranted; however, an evaluation of this magnitude is outside the scope of this investigation.

\section{BATHYMETRIC SURVEYS}

Bathymetric surveys were conducted before the collection of instream data and samples on each transect sampling excursion. The fathometer chart recorded the depth profile during each traverse of the cross-section line. Figure 13 portrays the depth profile at the 1987 transect location, approximately 2000 feet upstream of the Richland Pumphouse. This profile illustrates the primary channels in the river at this location. Also apparent in this figure are the downstream tip of the upper island (nearer the Benton County shoreline) and the upstream tip of the lower island. The maximum depth observed along this cross section during any one of the 1987 traverses was 23 feet. The minimum depth was 1.5 feet, observed while crossing the downstream tip of the upper island. The water level, as recorded from the Richland Pumphouse staff gage, varied by less than 1 foot during all of the sampling traverses. The water level dropped 0.9 foot and 0.7 foot during the August 27 and September 10 traverses, respectively. The water level was relatively stable during the August 31 sampling activities, rising only 0.1 foot.

The depth profile along the transect established during 1988 was more representative of a typical stream, with the exception of the presence of the island. The depth profile is shown in Figure 14, indicating the position of the island with respect to the river channels on either side. The maximum 


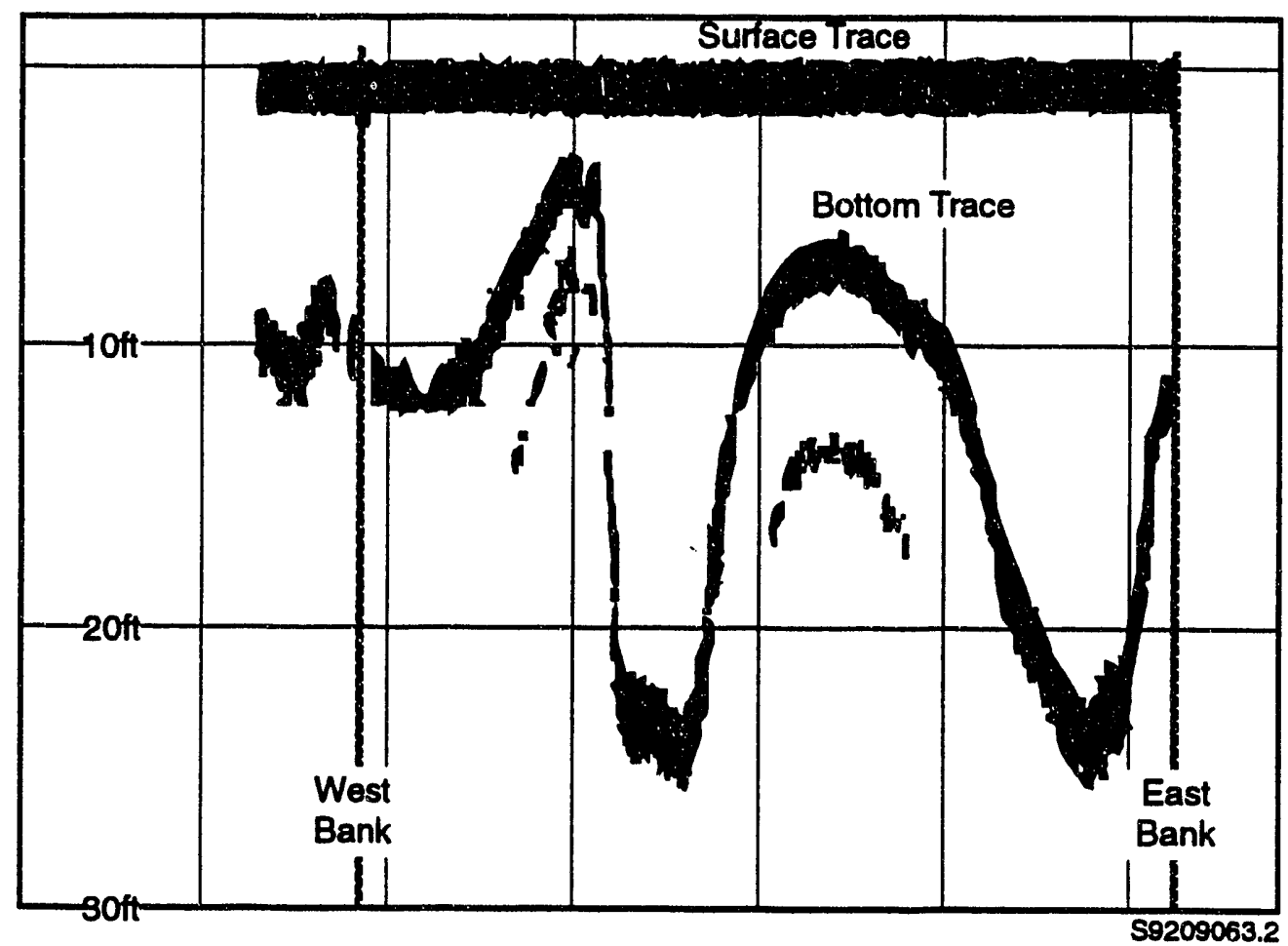

FIGURE 13. Richland Ferry Landing Transect Fathometer Chart

depth observed along this cross section was approximately 24 feet. The water level during the June 23, 1988, traverse varied by less than 0.1 foot in either direction over the course of the sampling activities. On August 5, 1988, the water level dropped 0.5 foot during the sampling traverse. Similarly, the river dropped 0.5 foot over the duration of the sampling activities performed on September 29, 1988 . Consistent with river flows, the water level at the Richland Pumphouse was highest during the June 23, 1988, sampling and lowest during the September 29, 1988, traverse.

\section{CURRENT VELOCITY}

Velocities measured during the 1987 traverses indicated the swiftest portions of the river to be paralleling the eastern shoreline and in the channel crossing from the east-to-west side between the islands, with the maximum velocities being observed in this channel. As is typical in most river systems, the lowest velocities were observed near the shorelines. The 


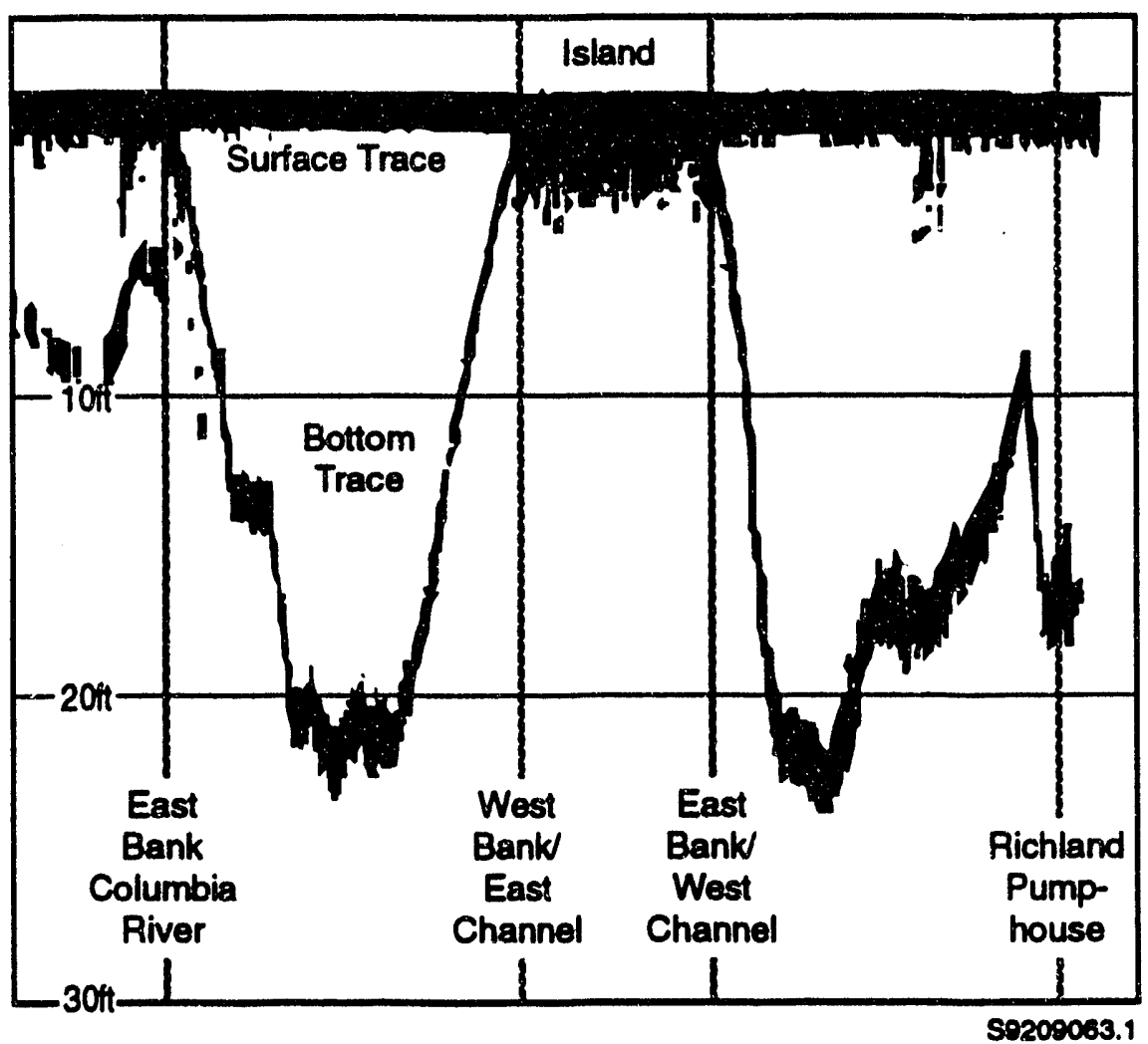

EIGURE 14. Richland Pumphouse Transect Fathometer Chart

influence of the island tips was readily apparent while making velocity measurements along the transect. Velocities near the downstream tip of the upper island decreased significantly, indicating a separation zone, while the upper end of the lower island split the flow into two obvious channels.

Table A.6, Appendix A, provides the vertical current velocity measurements obtained on August 27, 1987. As expected, the highest velocities at each station were found to be near the water surface. Vertically averaged velocities for the water column at each cross-section station are provided in Tables A.7, A.8, and A.9 for the sampling traverses conducted during 1987. An evaluation of the vertical velocity profiles, comparing the 10-point velocity calculation method with the 2-point method, indicates the 2-point method to be adequate in the determination of the vertically averaged velocities. All average velocities calculated using the 2-point method were within $5 \%$ of those calculated with the 10-point method, with an average variation of $2 \%$. As a 
result, velocity measurements were 1 imited to two depths during the 1988 sampling traverses. Vertically averaged velocities for each station during the 1988 traverses are shown in Tables A.10, A.11, and A.12.

\section{TRITIUM CONCENTRATIONS}

Water samples were collected along a cross section located at the old Richland Ferry Landing, just upstream of the Richland Pumphouse, on August 27, August 31, and September 10, 1987, as previous1y described. During 1988, water samples were collected on June 23, August 5, and September 29 at a transect located directly at the Richland Pumphouse. Water samples were collected at multiple depths at some stations along the cross section during the August 27, 1987, sampling traverse. Samples were collected from the river monitoring system located at the Richland Pumphouse concurrently with predetermined cross sectional samples during each of the sampling traverses. In 1987, samples were collected from the routine system concurrently at $50 \%$ of the cross-section stations. Concurrent Richland Pumphouse samples were collected for each cross-section station during 1988. Duplicate samples were collected at the cross-section stations and from the routine sampling system in some cases during each traverse as well to fulfill quality assurance needs.

Tritium concentrations obtained during this investigation are reported in Tables A.13 through A.19, Appendix A. Data are included for those samples collected along the cross sections; samples collected at depth at various cross-section stations during the August 27, 1987, traverse; and samples collected from the Richland Pumphouse. Samples collected concurrently at the Richland Pumphouse using the routine monitoring system are listed adjacent to the cross-section sample with which they are associated. Results of quality control samples are presented with the associated record sample result in Appendix $C$.

$\underline{1987}$

Figure 15 presents the tritium concentrations observed during each of the 1987 cross sections. Apparent in these figures is the relatively large uncertainty, approximately $30 \%$, associated with each of the results. The variability in the tritium concentrations and the uncertainties associated 


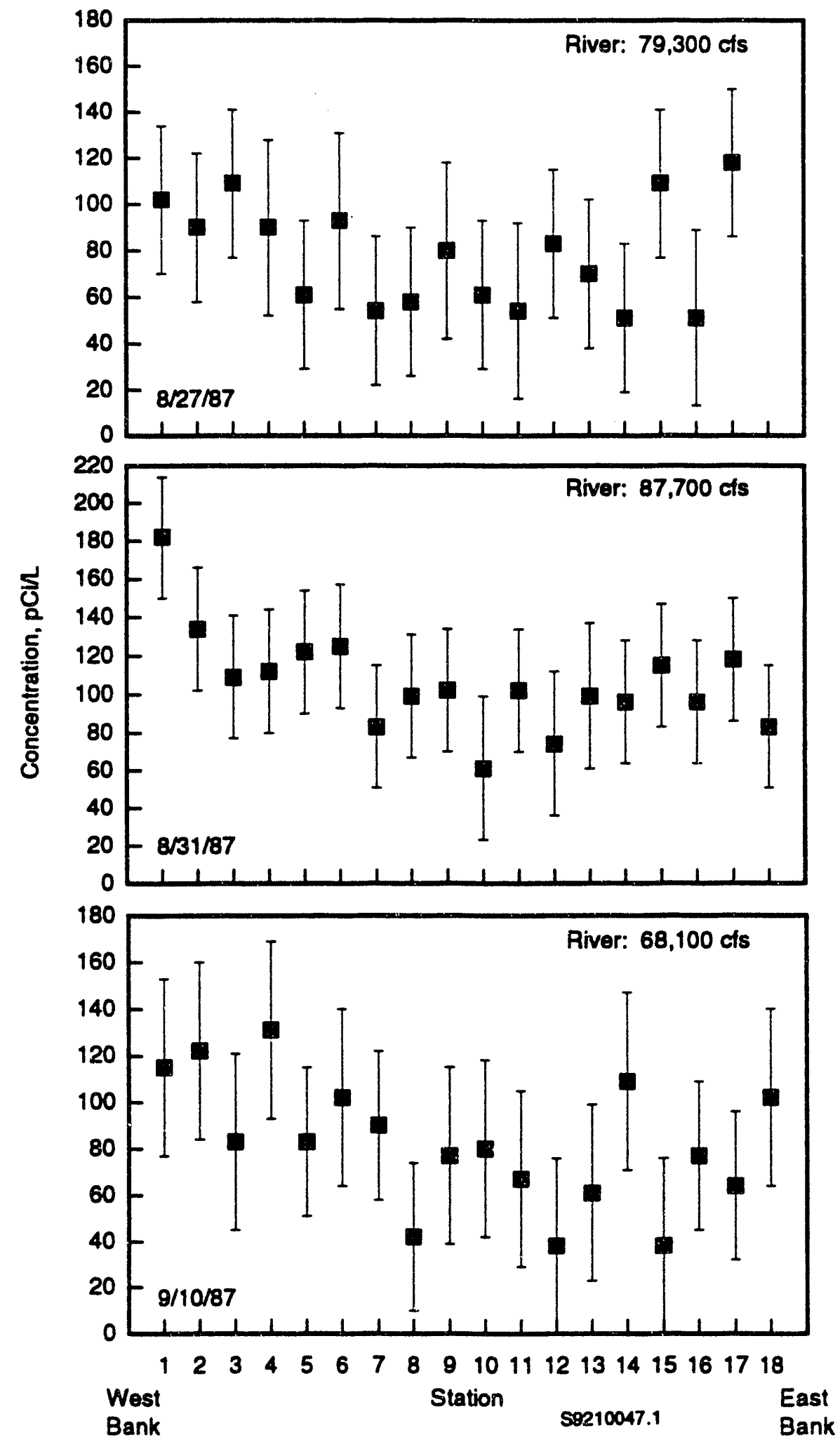

FIGURE 15. Tritium Concentrations Along the Richland Ferry Landing Cross Section, 1987 
with the individual results make it difficult to draw any meaningful conclusions relative to the distribution of tritium across the river. The variability observed may be a result of the analytical method used or may be associated with spatial and temporal variation in the tritium concentrations in the river water. Tritium concentrations fluctuated widely during the August 27, 1987, cross section, with no apparent gradient present. Tritium concentrations appear to decline slightly proceeding across the river from west to east during the August 31 cross section, although the tritium concentrations level off after the first approximately few hundred yards of the cross section. The results of the September 10, 1987, traverse were similar to those observed during the August 27, 1987, sampling: highly variable tritium concentrations across the river with no readily apparent gradient.

Figure 16 illustrates the relationship between the samples collected concurrently along the cross section and the Richland Pumphouse. The tritium concentrations in river water collected from the routine sampling system were consistently higher than those collected concurrently along the cross section. However, the uncertainties associated with the individual results generally overlapped. Statistical analysis of the differences, not taking into account the uncertainties associated with the results, indicate that the tritium concentrations at the Richland Pumphouse were significantly different (paired sample comparison, $t$ test of differences, $5 \%$ significance level) than those measured along the sampling traverse during the August 31 and September 10, 1987, cross sections (Snedecor and Cochran 1980). The difference observed during the cross-sectional sampling conducted on August 27, 1987, was not statistically significant at the $5 \%$ significance level, most likely because of the high degree of variability in the tritium measurements across the river.

Several stations were identified during the August 27, 1987, traverse from which water samples were collected from multiple depths. At these stations, samples were collected from depths $0.2,0.6$, and 0.8 times the river depth, measured down from the water surface. Figure 17 displays the sample results obtained during this effort. There is no consistent apparent relationship between tritium concentrations and depth. The insensitivity of the analytical method used in 1987 precludes conclusive discussion relative to the 

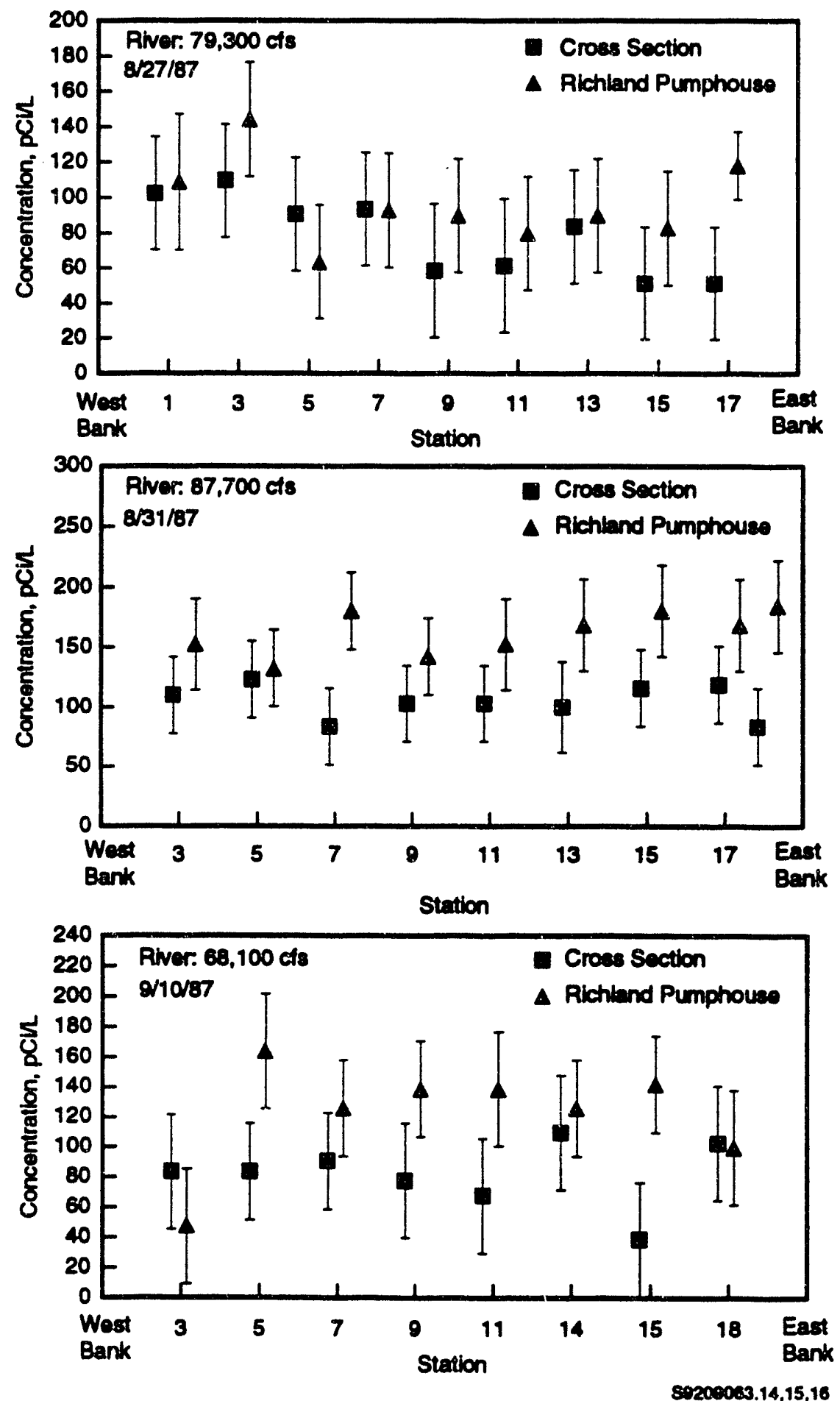

FIGURE 16. Comparison of Tritium Concentrations Along the Richland Ferry Landing Cross Section and at the Richl and Pumphouse, 1987 


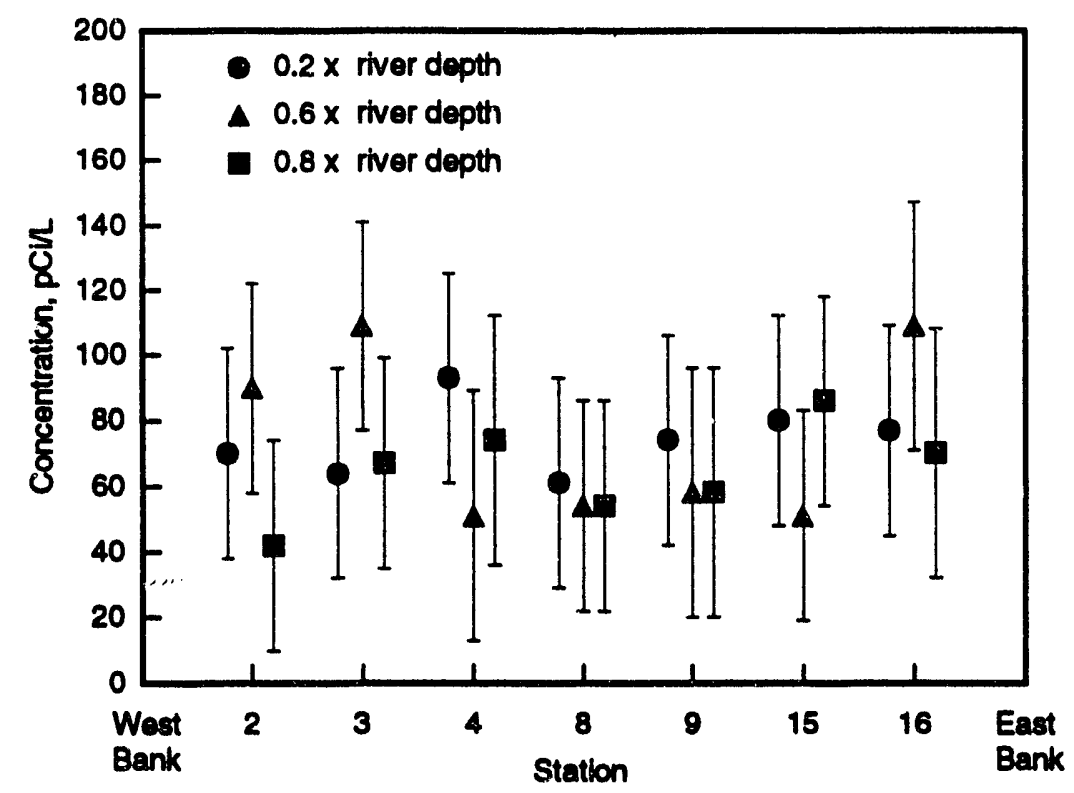

S9200063.17

\section{FIGURE 17. Tritium Concentrations Versus Depth Along the Richland Ferry Landing Cross Section, August 27, 1987}

vertical distribution of tritium in the Columbia River at the Richland Pumphouse. The uncertainties associated with the sample results overlap in all cases as is evident in the figure. In addition, the cross-section sample results indicate that the influence of the ground-water contaminants entering the river are 1 imited to near-shore samples (Figures 14 and 17), within approximately 300 yards. Only one of the stations sampled at multiple depths falls within this region of the river. Further study of the vertical distribution of tritium within the zone of influence of the ground water may be warranted. However, the low tritium concentrations present at any station within the river at the Richland Pumphouse minimizes the benefit of further study.

$\underline{1988}$

The 1988 cross-section tritium concentrations are displayed in Figure 18. Improvements in the sensitivity of the analytical method reduced the uncertainties associated with each sample result and allowed for meaningful interpretations of the data. Tritium concentrations across the river remained 


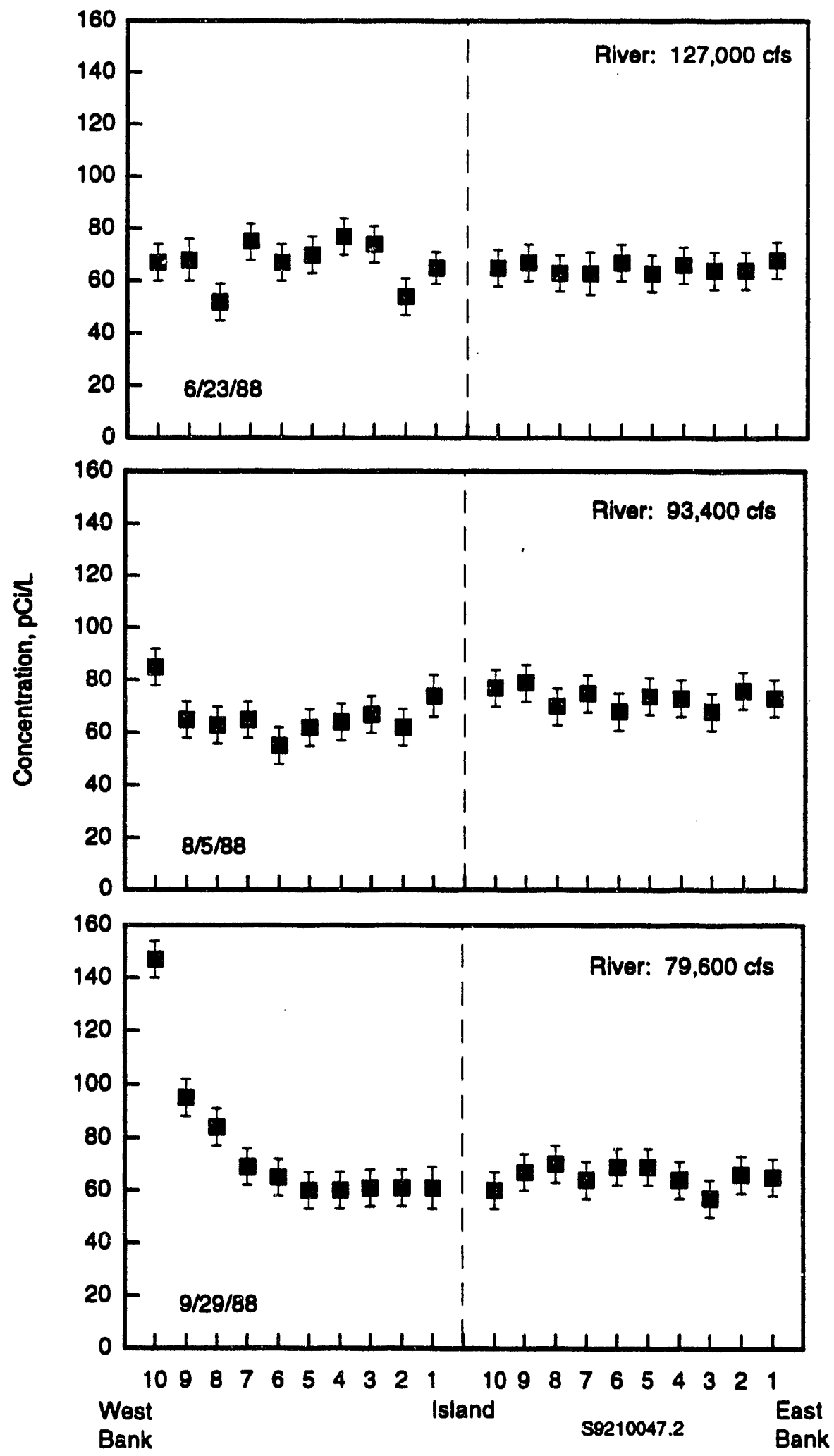

FIGURE 18. Tritium Concentrations Along the Richland Pumphouse Cross Section, 1988 
relatively constant during the June 23,1988 (high flow) sampling traverse. Similarly, with the exception of the near-shore sample, tritium concentrations were stable during near-average flow conditions (August 5, 1988). The data clearly indicate a concentration gradient proceeding across the river from the west bank to the east bank under low flow (September 29, 1988) conditions. The elevated tritium concentrations appear to remain within approximately 300 yards of the shoreline, consistent with past shoreline discharge dispersion studies and the findings of the 1987 sampling activities. Tritium concentrations at stations further from the shoreline (greater than 300 yards) approach typical background (upstream) concentrations.

The relationship between tritium concentrations in river water collected along the cross section and samples collected using the routine monitoring system at the Richland Pumphouse is evident in Figure 19. As expected, the differences are most evident and greatest during the sampling conducted under near average and low river flow conditions. Results of samples collected during high river discharge conditions indicate a relative flat concentration profile across the river and less difference between samples collected along the cross section and those collected from the routine monitoring system. Statistical analysis of the differences, not taking into account the uncertainties associated with the results, indicate that the tritium concentrations at the Richland Pumphouse were significantly different (5\% significance level) than those measured along the sampling traverse during all three 1988 cross sections.

Average Tritium Concentrations

The average tritium concentrations in Columbia River water as measured along a cross section and using the routine monitoring system during 1987 and 1988 are reported in Table A.20, Appendix A, and shown in Figure 20. The average tritium concentrations measured using the routine monitoring system were consisiently higher than the average river tritium concentrations measured along the cross section. The difference in the averages was determined to be statistically significant at the $5 \%$ significance level. Based on this 

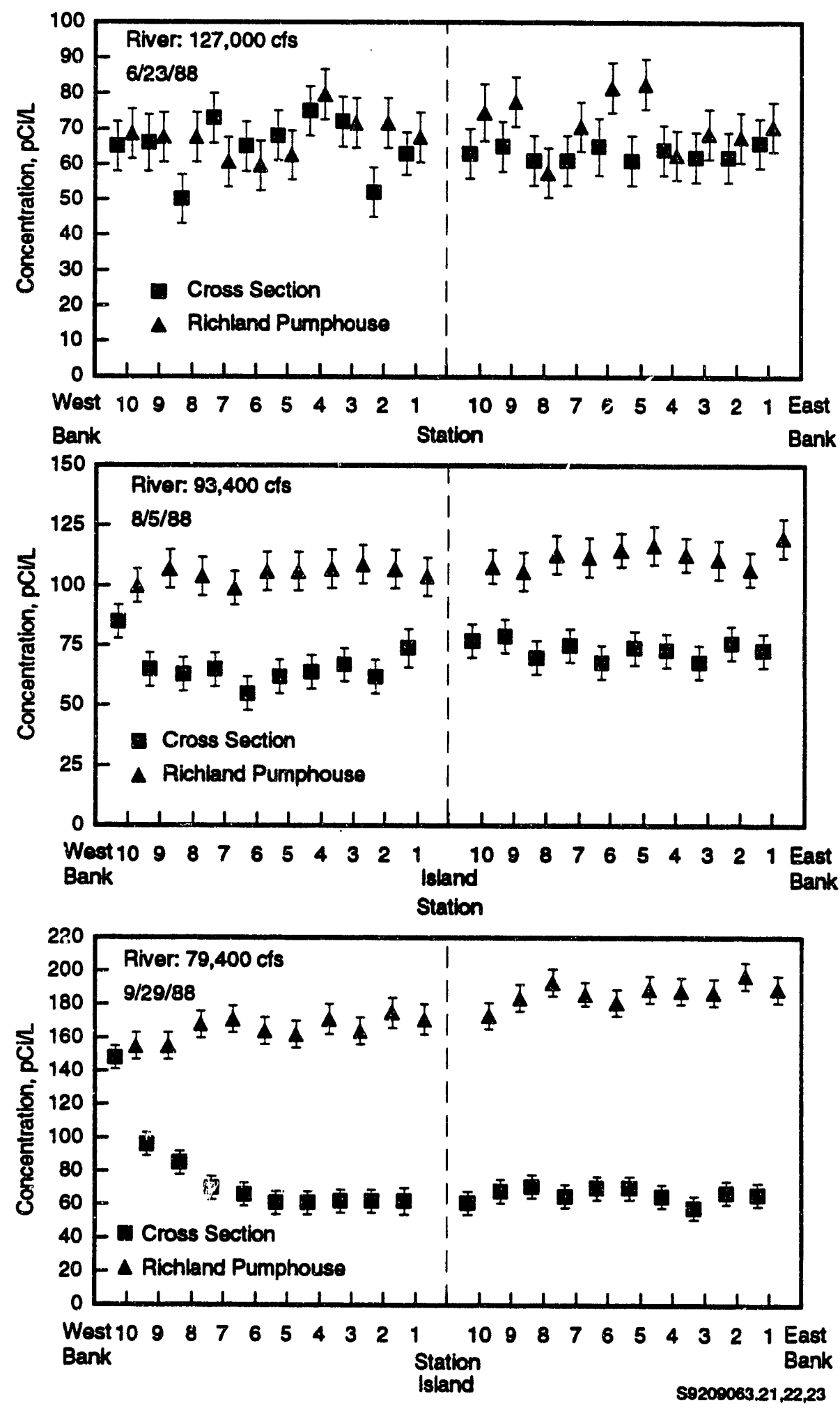

FIGURE 19. Comparison of Tritium Concentrations Along the Richland Pumphouse Cross Section and at the Richland Pumphouse, 1988 


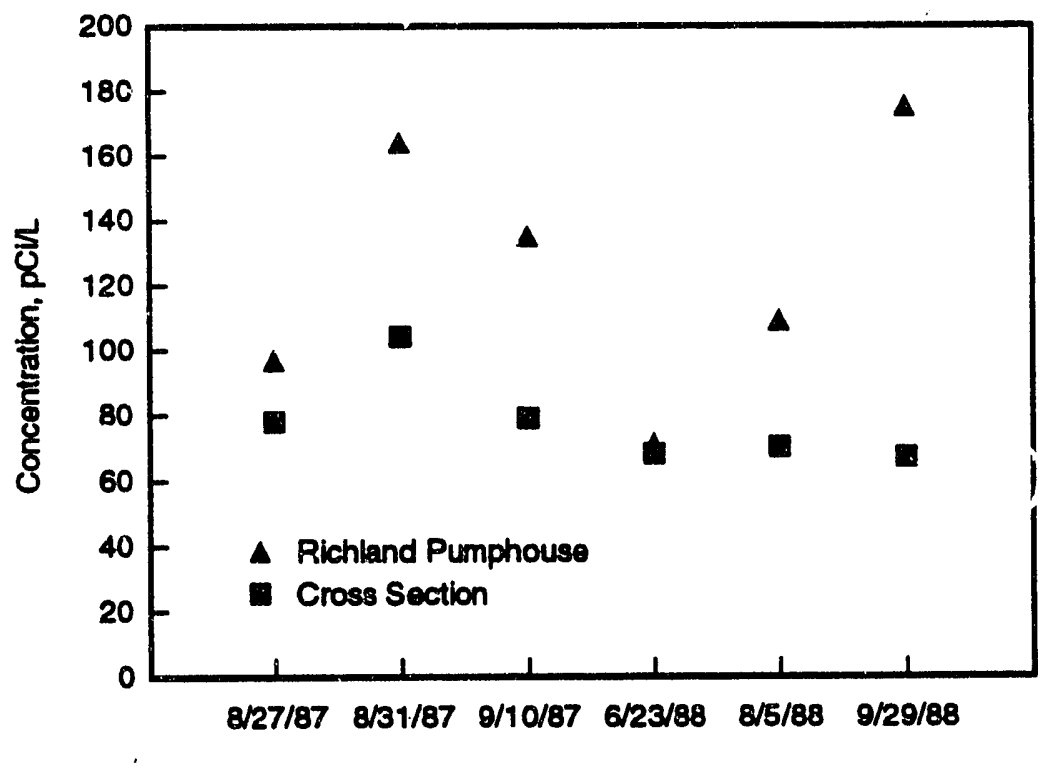

S9200063.24

FIGURE 20. Average Cross Section Tritium Concentration Versus Average Richland Pumphouse Tritium Concentration

study, sampling results obtained using the routine monitoring system overestimate the average tritium concentrations in Columbia River water at the Richland Pumphouse.

Attempts were made to estimate the bias associated with the data obtained using the routine river monitoring station located at the Richland Pumphouse. The ability to define the relationship between the tritium concentrations at the Richland Pumphouse and river discharge was 1 imited because of the relatively small number of sampling traverses. Figure 21 plots the bias, expressed as percent, against the daily average river flow for the respective sampling dates. The bias ranged from $4 \%$ to $161 \%$ with an average of approximately $62 \%$. While there is a definite indication that the bias decreases with increasing discharge, there is no distinct and consistent relationship between discharge and bias evident with the limited data available. In one instance the sample results obtained during similar discharges, 87,700 and $93,000 \mathrm{cfs}$, indicated the bias to be in good agreement, $58 \%$ and $56 \%$, respectively. Daily average flows immediately before both of these sampling 


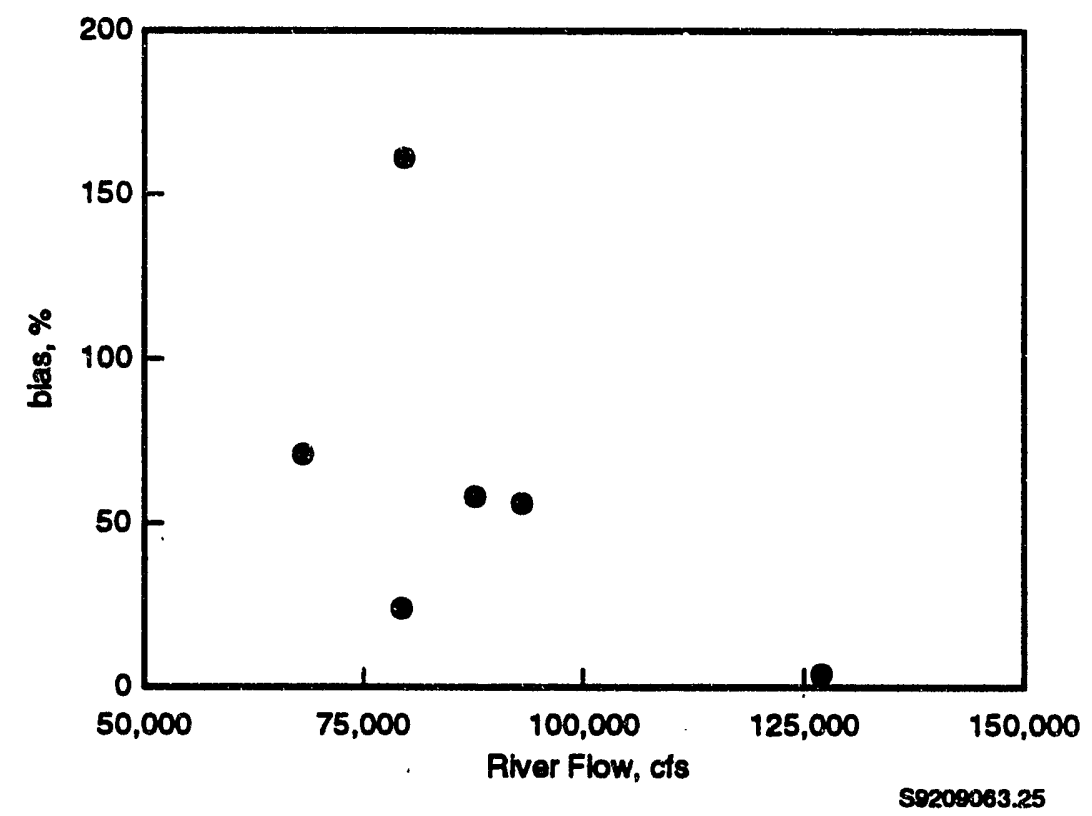

EIGURE_21. Bias in Tritium Concentrations Measured Along the Cross Section and the Richland Pumphouse

events were relatively constant (Figures 10 and 11 , Tables A.1 and A.4). However, in another case, comparing data collected during similar discharges, 79,300 and $79,600 \mathrm{cfs}$, revealed a range in bias of $24 \%$ to $161 \%$, respectively. The 24\% bias, which is lower than expected based on the other data, may be a result of much higher flow, 101,500 cfs, the day before sampling (Figure 10, Table A.1). The relationship between the contaminant concentrations in the river and river discharge, which is evident in this study, is dynamic and highly variable. Clearly, the interaction between the Hanford Site ground water, and the associated contaminants, and the Columbia River is complex and will require further study.

In recent years, routine monitoring daia have been used to calculate potential doses to the public in those cases where there is a measurable $d$ 'fference in the radionuclide concentrations upstream and downstream of the Site (Woodrurf et a1. 1992). Dose estimates, based on contaminant concentrations in the river at the Richland Pumphouse, provide an upper estimate of the potential dose received by any member of the public living near and using 
the Columbia River. Dose estimates calculated in this manner accurately reflect the potential dose received through the drinking water pathway by those using the city of Richland drinking water. 


\section{CONCLUSIONS}

Tritium concentrations in the Columbia River, which are well below drinking water standards, are significantly greater at the routine river monitoring station located at the Richland Pumphouse, downstream of the Hanford Site, than upstream at Priest Rapids Dam. The concentrations of tritium have been decreasing during recent years at both monitoring locations. Interestingly, the difference between concentrations observed at Priest Rapids Dam and the Richland Pumphouse has been increasing over the past few years.

Tritium is known to have entered the river along the Hanford Reach as direct effluent discharges; worldwide fallout from nuclear weapons testing, which have been virtually eliminated during recent years; and the seepage of ground water contaminated as a result of past operations at Hanford. The seepage of contaminated ground water has continued, expanding over time and encompassing a larger portion of the Hanford shoreline nearer the Richland Pumphouse river monitoring location.

Sampling was conducted along cross sections located at or near the Richland Pumphouse monitoring station to determine the distribution of tritium across the river and evaluate the relationship between average tritium concentrations in the river and in the routine river sampling system. Under certain river flow conditions, tritium concentrations were highest near the Benton County shoreline, Hanford side, of the river, decreasing with distance across the river. Tritium concentrations in samples collected from the routine monitoring system at the Richland Pumphouse were consistently elevated when compared with average river concentrations as determined through cross-sectional sampling. As expected, impacts were greatest during low river flow conditions.

Understanding the representativeness of the data is imperative in accurately characterizing the river environment and evaluating potential impacts attributable to Hanford operations. This study confirms that sampling at the Richland Pumphouse, the nearest point of water withdrawal for a public drinking water supply downstream of Hanford, provides an upper estimate of the potential dose received by the public through this pathway. The results also 
verify the conservative nature of impact assessments based on the river monitoring data, which tend to overestimate average river radionuclide concentrations as a result of the proximity of the contaminant source with the sampling location. 


\section{REFERENCES}

American Society for Testing Materials (ASTM). 1988. Standard Practice for Open-Channel Flow Measurement of Water by Velocity-Area Method. ASTM D 3858-79, American Society for Testing Materials, Philadelphia, Pennsylvania.

Backman, G. E. 1962. Dispersion of 300 Area Liquid Effluent in the Columbia River. HW-73672, General Electric Company, Hanford Atomic Products Operation, Richland, Washington.

Becker, C. D. 1990. Aquatic Bioenvironmental Studies: The Hanford Experience, 1944-84. Elsevier Science Publishing Company Inc., New York.

Buske, N., and L. Josephson. 1986. Spring 1986 Data Report. SEARCH Technical Services, Davenport, Washington.

Buske, N., and L. Josephson. 1987. Accounting a Few Radionuclides from Hanford Groundwater. SEARCH Technical Services, Davenport, Washington.

Clean Water Act. Public Law 95-217, December 27, 1977, 91 Stat. 1566 and Public Law 96-148.

Cline, C. S., J. T. Rieger, and J. R. Raymond. 1985. Ground-Water Monitoring at the Hanford Site, January-December 1984. PNL-5408, Pacific Northwest Laboratory, Richland, Washington.

Cushing, C. E., D. G. Watson, A. J. Scott, and J. M. Gurtisen. 1981. "Decrease of Radionuclides in Columbia River Biota Following Closure of Hanford Reactors." Health Physics 41:59-67.

Dirkes, R. L. 1990. 1988 Hanford Riverbank Springs Characterization Report. PNL-7500, Pacific Northwest Laboratory, Richland, Washington.

Evans, J. C., R. W. Bryce, and D. R. Sherwood. 1989a. Hanford Site GroundWater Monitoring for January Through June 1988. PNL-6886, Pacific Northwest Laboratory, Richland, Washington.

Evans, J. C., R. W. Bryce, D. R. Sherwood, M. L. Kemner, and D. R. Newcomer. $1989 \mathrm{~b}$. Hanford Site Ground-Water Monitoring for July Through December 1988.

PNL-7120, Pacific Northwest Laboratory, Richland, Washington.

Evans, J. C., R. W. Bryce, and D. J. Bates. 1992. Hanford Site Ground-Water Monitoring for 1991. PNL-8284, Pacific Northwest Laboratory, Richland, Washington.

Freshley, M. D., and M. J. Graham. 1988. Estimation of Ground-Water Travel Time at the Hanford Site: Description, Past Work, and Future Needs. PNL-6328, Pacific Northwest Laboratory, Richland, Washington. 
Haney, W. A. 1957. Dilution of 300 Area Uranium Wastes Entering the Columbia River. HW-52401, General Electric Company, Hanford Atomic Products Operation, Richland, Washington.

Honstead, J. F. 1954. Columbia River Survey 1951, 1952, 1953. HW-32506, General Electric Company, Hanford Atomic Products Operation, Richland, Washington.

Honstead, J. F. 1957. Dispersion of Dissolved Material in the Columbia River. HW-49008, General Electric Company, Hanford Atomic Products Operation, Richland, Washington

Honstead, J. F., J. W. Healy, and H. J. Paas. 1951. Columbia River Survey Preliminary Report. HW-22851, AEC Research and Development Report, Hanford Atomic Products Operation, Richland, Washington.

Jaquish, R. J., and P. J. Mitchell, editors. 1988. Hanford Site Environmental Report for Calendar Year 1987. PNL-6464, Pacific Northwest Laboratory, Richland, Washington.

Jaquish, R. J., and R. W. Bryce, editors. 1989. Hanford Site Environmental Report for Calendar Year 1988. PNL-6825, Pacific Northwest Laboratory, Richland, Washington.

Jaquish, R. J., and R. W. Bryce, editors. 1990. Hanford Site Environmental Report for Calendar Year 1989. PNL-7346, Pacific Northwest Laboratory, Richland, Washington.

Jenkins, 0. P. 1922. Underground Water Supply of the Region About White Bluffs and Hanford. State of Washington, Department of Conservation and Development, Olympia, Washington.

Lettenmaier, D. P. and Associates. 1988. Review and Recommendations on PNL Surface Water Monitoring. DPL and Associates, Seattle, Washington.

Liikala, T. L., R. L. Aaberg, N. J. Aimo, D. J. Bates, T. J. Gilmore, E. J. Jensen, G. V. Last, P. L. Oberlander, K. B. 01 sen, K. R. Oster, L. R. Roome, J. C. Simpson, S. S. Teel, and E. J. Westergard. 1988. Geohydrologic Characterization of the Area Surrounding the 183-H Solar Evaporation Basins. PNL-6728, Pacific Northwest Laboratory, Richland, Washington.

McCormack, W. D., and J. M. V. Carlile. 1984. Investigation of Ground-Water Seepage from the Hanford Shoreline of the Columbia River. PNL-5289, Pacific Northwest Laboratory, Richland, Washington.

McGavock, E. H., W. D. Wiggens, R. L. Blazs, P. R. Boucher, L. L. Reed, and M. C. Smith. 1987. Water Resources Data Washington Water Year 1985.

U.S. Geological Survey, Tacoma, Washington. 
Norton, H. T. 1957. The Turbulent Diffusion of River Contaminants. $H W-49195$, General Electric Company, Hanford Atomic Products Operation, Richland, Washington.

Pacific Northwest Laboratory (PNL). 1989. Procedures for Ground-Water Investigations. PNL-6894, Pacific Northwest Laboratory, Richland, Washington.

Raymond, J. R., and D. J. Brown. 1963. Ground Water Exchange With Fluctuating Rivers. HW-SA-3198, General Electric Company, Hanford Atomic Products Operation, Richland, Washington.

Rokkan, D. J. 1988. Westinghouse Hanford Company 100 Areas Environmental Releases for 1987. WHC-EP-0165, Westinghouse Hanford Company, Richland, Washington.

Schalla, R., R. W. Wallace, R. L. Aaberg, S. P. Airhart, D. J. Bates, J. M. Carlile, C. S. Cline, D. I. Dennison, M. D. Freshiy, T. R. Heller, E. J. Jensen, K. B. 01 sen, R. G. Parkhurst, J. T. Rieger, and E. J. Westergard. 1988. Interim Characterization Report for the 300 Area Process Trenches. PNL-6716, Pacific Northwest Laboratory, Richland, Washington.

Snedecor, G. W., and W. G. Cochran. 1980. Statistical Methods. 7th ed. Iowa State University Press, Ames, Iowa.

Soldat, J. K. 1962. A Compilation of Basic Data Relating to the Columbia River Section 8 - Dispersion of Reactor Effluent in the Columbia River. HW-69369, General Electric Company, Hanford Atomic Products Operation, Richland, Washington.

Sonnichsen, J. C., Jr., D. A. Kottwitz, and R. T. Jaske. 1970. Dispersion Characteristics of the Columbia River Between River Miles 383 and 355 . BNWL-1477, Battelle, Pacific Northwest Laboratories, Richland, Washington.

U.S. Department of Energy (DOE). 1987. Effluent Information System (EIS)/ Onsite Discharge Information System (ODIS). DOE/ID-187 (87), Idaho Operations Office, Idaho Falls, Idaho.

U.S. Department of Energy (DOE). 1991. Environmental Requlatory Guide for Radiological Effluent Monitoring and Environmental Surveillance.

DOE/EH-0173T, U.S. Department of Energy, Washington, D.C.

U.S. Department of Energy (DOE), Richland Field Office (RL). 1992. Sampling and Analysis of 100 Area Springs. DOE/RL-92-12, Revision 1, U.S. Department of Energy, Richland, Washington.

U.S. Geological Survey (USGS). 1987. Subsurface Transport of Radionuclides in Shallow Deposits of the Hanford Nuclear Reservation. Washington--Review of Selected Previous Work and Suggestions for Further Study. Open-File Report 87-222, U.S. Geological Survey, Reston, Virginia. 
Washington State Department of Ecology (WDOE). 1982. Water Quality Standards for Waters of the State of Washington. Washington Administrative Code, Chapter 173-201, 01ympia, Washington.

Woodruff, R. K., R. W. Hanf, M. G. Hefty, and R. E. Lundgren, editors. 1991. Hanford Site Environmental Report for Calendar Year 1990. PNL-7930, Pacific Northwest Laboratory, Richland, Washington.

Woodruff, R. K., R. W. Hanf, and R. E. Lundgren, editors. 1992. Hanford Site Environmental Report for Calendar Year 1991. PNL-8148, Pacific Northwest Laboratory, Richland, Washington. 
APPENDIX A

RIVER FLOW, CURRENT VELOCITY, AND TRITIUM CONCENTRATION DATA 
TABLE A.1. Daily Average Columbia River Flows,

August 17, 1987 Through September 15, 1987

\begin{tabular}{|c|c|c|c|}
\hline \multicolumn{2}{|l|}{ Date } & \multicolumn{2}{|c|}{ Flow, cfs } \\
\hline \multirow[t]{10}{*}{ August } & 17 & 74,200 & \\
\hline & 18 & 81,000 & \\
\hline & 19 & 78,900 & \\
\hline & 20 & 96,300 & \\
\hline & 21 & 99,500 & \\
\hline & 22 & 69,900 & \\
\hline & 23 & 60,800 & \\
\hline & 24 & 95,000 & \\
\hline & 25 & 96,600 & \\
\hline & 26 & 101,500 & \\
\hline \multirow[t]{4}{*}{$\rightarrow$} & 27 & 79,300 & (Sample Traverse) \\
\hline & 28 & 96,200 & \\
\hline & 29 & 80,500 & \\
\hline & 30 & 79,600 & \\
\hline$\rightarrow$ & 31 & 87,700 & (Sample Traverse) \\
\hline \multirow[t]{9}{*}{ September } & 1 & 89,500 & \\
\hline & 2 & 91,300 & \\
\hline & 3 & 105,000 & \\
\hline & 4 & 82,500 & \\
\hline & 5 & 52,000 & \\
\hline & 6 & 47,500 & \\
\hline & 7 & 64,300 & \\
\hline & 8 & 82,100 & \\
\hline & 9 & 78,900 & \\
\hline \multirow[t]{6}{*}{$\rightarrow$} & 10 & 68,100 & (Sample Traverse) \\
\hline & 11 & 92,800 & \\
\hline & 12 & 100,000 & \\
\hline & 13 & 64,400 & \\
\hline & 14 & 101,000 & \\
\hline & 15 & 89,500 & \\
\hline
\end{tabular}

A.1 
TABLE A.2. Daily Average Columbia River Flows, June 13, 1988 Through June 28, 1988

\begin{tabular}{rrr} 
Date & & Flow, cfs \\
\cline { 4 - 4 } June 13 & & 106,000 \\
14 & 98,600 \\
15 & 110,000 \\
16 & 123,000 \\
17 & 119,000 \\
18 & 108,000 \\
19 & 62,300 \\
20 & 94,900 \\
21 & 119,000 \\
22 & 123,000 \\
23 & 127,000 \\
24 & 132,000 \\
25 & 125,000 \\
26 & 72,000 \\
27 & 95,000 \\
28 & 94,300
\end{tabular}


TABLE A.3. Daily Average Columbia River Flows, July 26, 1988 Through August 10, 1988

\begin{tabular}{rrr}
\multicolumn{1}{c}{ Date } & Flow, cfs \\
July 26 & & 86,300 \\
27 & 76,800 \\
28 & 64,100 \\
29 & 69,600 \\
30 & 61,700 \\
31 & 49,500 \\
August 1 & 78,300 \\
2 & 77,900 \\
3 & 80,600 \\
4 & 86,000 \\
5 & 93,400 \\
6 & 79,500 \\
7 & 49,600 \\
8 & 85,300 \\
9 & 92,200 \\
10 & 85,800
\end{tabular}

A.3 
IABLE A.4. Daily Average Columbia River Flows,

September 19, 1988 Through October 4, 1988

\begin{tabular}{rrr}
\multicolumn{1}{c}{ Date } & \multicolumn{1}{c}{ Flow, cfs } \\
\cline { 3 - 4 } September 19 & 87,600 \\
20 & 102,000 \\
21 & 98,700 \\
22 & 88,600 \\
23 & 75,800 \\
24 & 102,000 \\
25 & 65,200 \\
26 & 82,000 \\
27 & 92,800 \\
28 & 80,600 \\
29 & 79,600 \\
30 & 75,400 & (Sample Traverse) \\
October 1 & 55,100 \\
2 & 48,800 \\
3 & 81,200 \\
4 & 88,100
\end{tabular}


TABLE A.5. Annual Average Columbia River Flows, 1980-1990

\begin{tabular}{|c|c|}
\hline Date & Flow, cfs \\
\hline 1980 & 103,000 \\
\hline 1981 & 132,000 \\
\hline 1982 & 140,000 \\
\hline 1983 & 131,000 \\
\hline 1984 & 112,000 \\
\hline 1985 & 107,000 \\
\hline 1986 & 108,000 \\
\hline 1987 & 101,000 \\
\hline 1988 & 100,000 \\
\hline 1989 & 99,400 \\
\hline 1990 & 137,000 \\
\hline
\end{tabular}

A. 5 


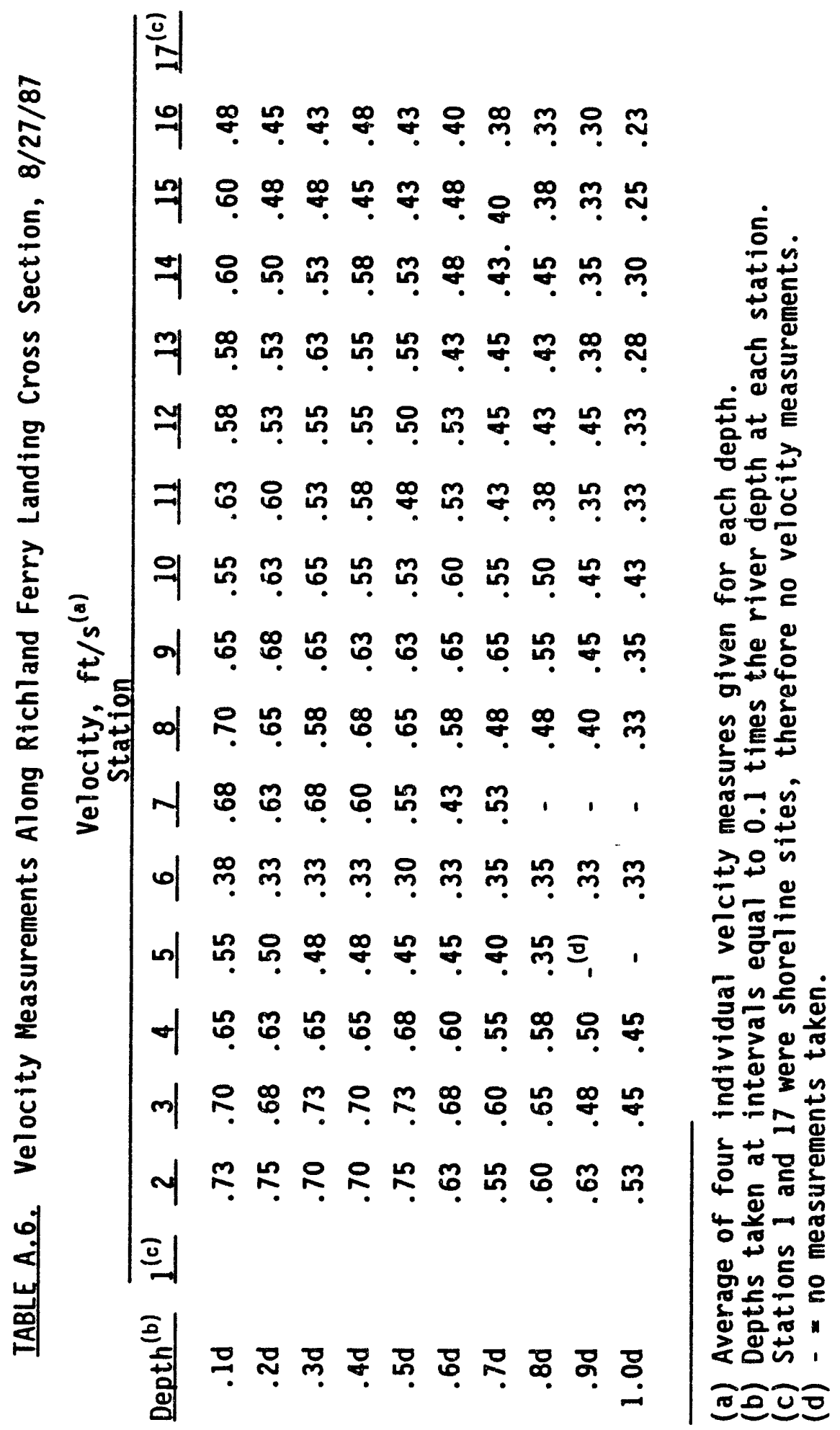


TABLE A.7. Vertically Averaged Velocity for Each Richland Ferry Landing Transect Station, August 27, 1987

\begin{tabular}{|c|c|}
\hline $\begin{array}{l}\text { Station } \\
\text { Number } \\
\end{array}$ & $\begin{array}{l}\text { Vertically Averaged } \\
\text { Velocity, ft/s } \\
\end{array}$ \\
\hline 1 & BC Shoreline \\
\hline 2 & 0.65 \\
\hline 3 & 0.64 \\
\hline 4 & 0.59 \\
\hline 5 & 0.46 \\
\hline 6 & 0.33 \\
\hline 7 & 0.58 \\
\hline 8 & 0.55 \\
\hline 9 & 0.59 \\
\hline 10 & 0.54 \\
\hline 11 & 0.48 \\
\hline 12 & 0.49 \\
\hline 13 & 0.48 \\
\hline 14 & 0.47 \\
\hline 15 & 0.43 \\
\hline 16 & 0.39 \\
\hline 17 & FC Shoreline \\
\hline
\end{tabular}

A.7 
TABLE A.8. Vertically Averaged Velocity for Each Richland Ferry Landing Transect Station, August 31, 1987

\begin{tabular}{|c|c|}
\hline $\begin{array}{l}\text { Station } \\
\text { Number } \\
\end{array}$ & $\begin{array}{c}\text { Vertically Averaged } \\
\text { Velocity, } \mathrm{ft} / \mathrm{s} \\
\end{array}$ \\
\hline 1 & BC Shoreline \\
\hline 2 & 0.55 \\
\hline 3 & 0.54 \\
\hline 4 & 0.48 \\
\hline 5 & 0.37 \\
\hline 6 & 0.36 \\
\hline 7 & 0.59 \\
\hline 8 & 0.61 \\
\hline 9 & 0.61 \\
\hline 10 & 0.57 \\
\hline 11 & 0.54 \\
\hline 12 & 0.56 \\
\hline 13 & 0.57 \\
\hline 14 & 0.59 \\
\hline 15 & 0.55 \\
\hline 16 & 0.54 \\
\hline 17 & 0.47 \\
\hline 18 & FC Shoreline \\
\hline
\end{tabular}

A. 8 
TABLE A.9. Vertically Averaged Velocity for Each Richland Ferry Landing Transect Station, September 10, 1987

\begin{tabular}{cc}
$\begin{array}{c}\text { Station } \\
\text { Number }\end{array}$ & $\begin{array}{c}\text { Vertically Averaged } \\
\text { Velocity, ft/s }\end{array}$ \\
\cline { 2 - 2 } 1 & BC Shoreline \\
2 & 0.51 \\
3 & 0.53 \\
4 & 0.45 \\
5 & 0.35 \\
6 & 0.27 \\
7 & 0.46 \\
8 & 0.52 \\
9 & 0.49 \\
10 & 0.45 \\
11 & 0.40 \\
12 & 0.42 \\
13 & 0.42 \\
14 & 0.41 \\
15 & 0.40 \\
16 & 0.37 \\
17 & 0.32 \\
18 & Shoreline \\
&
\end{tabular}

A. 9 
TABLE A.10. Vertically Averaged Velocity for Each Richland Pumphouse Transect Station, June 23, 1988

\begin{tabular}{lc}
$\begin{array}{c}\text { Station } \\
\text { Number }\end{array}$ & $\begin{array}{c}\text { Vertically Averaged } \\
\text { Velocity, ft/s }\end{array}$ \\
\cline { 2 - 2 } EC1 & 0.58 \\
EC2 & 0.81 \\
EC3 & 0.66 \\
EC4 & 0.86 \\
EC5 & 0.94 \\
EC6 & 0.94 \\
EC7 & 0.94 \\
EC8 & 0.84 \\
EC9 & 0.60 \\
EC10 & 0.30 \\
WC1 & 0.28 \\
WC2 & 0.57 \\
WC3 & 0.89 \\
WC4 & 1.06 \\
WC5 & 0.92 \\
WC6 & 0.84 \\
WC7 & 0.89 \\
WC8 & 0.85 \\
WC9 & 0.66 \\
WC10 & 0.33
\end{tabular}


TABLE A.11. Vertically Averaged Velocity for Each Richland Pumphouse Transect Station, August 5, 1988

\begin{tabular}{cc}
$\begin{array}{c}\text { Station } \\
\text { Number }\end{array}$ & $\begin{array}{c}\text { Vertically Averaged } \\
\text { Velocity, ft/s }\end{array}$ \\
\cline { 2 - 2 } EC1 & 0.42 \\
EC2 & 0.63 \\
EC3 & 0.62 \\
EC4 & 0.81 \\
EC5 & 0.79 \\
EC6 & 0.81 \\
EC7 & 0.69 \\
EC8 & 0.59 \\
EC9 & 0.44 \\
EC10 & 0.25 \\
WC1 & 0.18 \\
WC2 & 0.38 \\
WC3 & 0.59 \\
WC4 & 0.71 \\
WC5 & 0.68 \\
WC6 & 0.53 \\
WC7 & 0.55 \\
WC8 & 0.55 \\
WC9 & 0.44 \\
WC10 & 0.22
\end{tabular}


TABLE A.12. Vertically Averaged Velocity for Each Richland Pumphouse Transect Station, September 29, 1988

\begin{tabular}{ccc}
$\begin{array}{cc}\text { Station } \\
\text { Number }\end{array}$ & \multicolumn{2}{c}{$\begin{array}{c}\text { Vertically Averaged } \\
\text { Velocity, ft/s }\end{array}$} \\
\cline { 3 - 3 } EC1 & 0.47 \\
EC2 & 0.59 \\
EC3 & 0.61 \\
EC4 & 0.65 \\
EC5 & 0.65 \\
EC6 & 0.68 \\
EC7 & 0.64 \\
EC8 & 0.58 \\
EC9 & 0.33 \\
EC10 & 0.23 \\
WC1 & 0.16 \\
WC2 & 0.25 \\
WC3 & 0.56 \\
WC4 & 0.59 \\
WC5 & 0.53 \\
WC6 & 0.50 \\
WC7 & 0.50 \\
WC8 & 0.48 \\
WC9 & 0.40 \\
WC10 & 0.10
\end{tabular}

A. 12 
TABLE A.13. Tritium Concentrations Along Richland Ferry Landing Cross Section and at the Richland Pumphouse, August 27, 1987

\begin{tabular}{|c|c|c|c|}
\hline \multicolumn{2}{|c|}{ Cross Section } & Richland & \multirow{2}{*}{$\begin{array}{c}\text { Pumphouse } \\
\text { Concentration } \\
\mathrm{pCi} / \mathrm{L}\end{array}$} \\
\hline $\begin{array}{l}\text { Sample } \\
\text { Number }\end{array}$ & $\begin{array}{c}\text { Concentration } \\
\mathrm{pC} i / L\end{array}$ & $\begin{array}{l}\text { Sample } \\
\text { Number }\end{array}$ & \\
\hline 1 & $102 \pm 32$ & $\mathrm{RP} 1$ & $109 \pm 32^{(a)}$ \\
\hline 2 & $90 \pm 32$ & & \\
\hline 3 & $109 \pm 32$ & $\mathrm{RP} 2$ & $144 \pm 38$ \\
\hline 4 & $51 \pm 38$ & & \\
\hline 5 & $90 \pm 32$ & RP 3 & $64 \pm 32$ \\
\hline 6 & $61 \pm 38$ & & \\
\hline 7 & $93 \pm 32$ & RP 4 & $93 \pm 32$ \\
\hline 8 & $54 \pm 32$ & & \\
\hline 9 & $58 \pm 38$ & RP 5 & $90 \pm 32$ \\
\hline 10 & $80 \pm 32$ & & \\
\hline 11 & $61 \pm 38$ & $\mathrm{RP} 6$ & $80 \pm 32$ \\
\hline 12 & $54 \pm 32$ & & \\
\hline 13 & $83 \pm 32$ & $\mathrm{RP} 7$ & $90 \pm 32$ \\
\hline 14 & $70 \pm 32$ & & \\
\hline 15 & $51 \pm 32$ & RP 8 & $83 \pm 32$ \\
\hline 16 & $109 \pm 38$ & & \\
\hline 17 & $51 \pm 32$ & $\mathrm{RP} 9$ & $118 \pm 32$ \\
\hline
\end{tabular}

(a) Samples collected concurrently with corresponding cross section sample. 
IABLE A.14. Tritium Concentrations at Various Depths at Selected Stations Along the Richland Ferry Landing Cross Section, August 27, 1987

Concentration, $\mathrm{pCi} / \mathrm{L}$

\begin{tabular}{|c|c|c|c|}
\hline Station & 0.2 depth & 0.6 depth & 0.8 depth \\
\hline 2 & $70 \pm 32$ & $90 \pm 32$ & $42 \pm 32$ \\
\hline 3 & $64 \pm 32$ & $109 \pm 32$ & $67 \pm 32$ \\
\hline 4 & $93 \pm 32$ & $51 \pm 38$ & $74 \pm 32$ \\
\hline 8 & $61 \pm 32$ & $54 \pm 32$ & $54 \pm 32$ \\
\hline 9 & $74 \pm 32$ & $58 \pm 38$ & $58 \pm 38$ \\
\hline 15 & $80 \pm 32$ & $51 \pm 32$ & $86 \pm 32$ \\
\hline 16 & $77+32$ & $109 \pm 38$ & $70 \pm 38$ \\
\hline
\end{tabular}


TABLE A.15. Tritium Concentrations Along Richland Ferry Landing Cross Section and at the Richland Pumphouse, August 31, 1987

\begin{tabular}{|c|c|c|c|}
\hline \multicolumn{2}{|c|}{ Cross Section } & \multicolumn{2}{|c|}{ Richland Pumphouse } \\
\hline $\begin{array}{l}\text { Sample } \\
\text { Number } \\
\end{array}$ & $\begin{array}{c}\text { Concentration, } \\
\mathrm{pCi} / \mathrm{L}\end{array}$ & $\begin{array}{l}\text { Sample } \\
\text { Number }\end{array}$ & $\begin{array}{c}\text { Concentration, } \\
\mathrm{pCi} \mathrm{L} / \mathrm{L}\end{array}$ \\
\hline 1 & $182 \pm 32$ & & \\
\hline 2 & $134 \pm 32$ & & \\
\hline 3 & $109 \pm 32$ & RP 1 & $154 \pm 38^{(\mathrm{a})}$ \\
\hline 4 & $112 \pm 32$ & & \\
\hline 5 & $122 \pm 32$ & $\mathrm{RP} 2$ & $134 \pm 32$ \\
\hline 6 & $125 \pm 38$ & & \\
\hline 7 & $83 \pm 32$ & $\mathrm{RP} 3$ & $182 \pm 32$ \\
\hline 8 & $99 \pm 32$ & & \\
\hline 9 & $102 \pm 38$ & RP 4 & $144 \pm 32$ \\
\hline 10 & $61 \pm 38$ & & \\
\hline 11 & $102 \pm 32$ & RP 5 & $154 \pm 38$ \\
\hline 12 & $74 \pm 38$ & & \\
\hline 13 & $99 \pm 38$ & $\mathrm{RP} 6$ & $170 \pm 38$ \\
\hline 14 & $96 \pm 32$ & & \\
\hline 15 & $115 \pm 32$ & RP 7 & $182 \pm 38$ \\
\hline 16 & $96 \pm 32$ & & \\
\hline 17 & $118 \pm 32$ & RP 8 & $170 \pm 38$ \\
\hline 18 & $83 \pm 32$ & $\mathrm{RP} 9$ & $186 \pm 38$ \\
\hline
\end{tabular}

(a) Indicates samples were collected concurrently. 
TABLE A.16. Tritium Concentrations Along Richland Ferry Landing Cross Section and at the Richland Pumphouse, September 10, 1987

\begin{tabular}{|c|c|c|c|}
\hline \multicolumn{2}{|c|}{ Cross Section } & \multicolumn{2}{|c|}{ Richland Pumphouse } \\
\hline $\begin{array}{l}\text { Sample } \\
\text { Number } \\
\end{array}$ & $\begin{array}{c}\text { Concentration, } \\
\mathrm{pCi} \mathrm{L}\end{array}$ & $\begin{array}{l}\text { Sample } \\
\text { Number } \\
\end{array}$ & $\begin{array}{c}\text { Concentration, } \\
\mathrm{pCi} / \mathrm{L}\end{array}$ \\
\hline 1 & $115 \pm 38$ & & \\
\hline 2 & $122 \pm 38$ & & \\
\hline 3 & $83 \pm 38$ & RP 1 & $147 \pm 38^{(\mathrm{a})}$ \\
\hline 4 & $131 \pm 38$ & & \\
\hline 5 & $83 \pm 32$ & RP 2 & $163 \pm 38$ \\
\hline 6 & $102 \pm 38$ & & \\
\hline 7 & $90 \pm 32$ & RP 3 & $125 \pm 32$ \\
\hline 8 & $42 \pm 32$ & & \\
\hline 9 & $77 \pm 38$ & RP 4 & $138 \pm 32$ \\
\hline 10 & $80 \pm 38$ & & \\
\hline 11 & $67 \pm 38$ & RP 5 & $138 \pm 38$ \\
\hline 12 & $67 \pm 67$ & & \\
\hline 13 & $61 \pm 38$ & & \\
\hline 14 & $109 \pm 38$ & RP 6 & $125 \pm 32$ \\
\hline 15 & $38 \pm 38$ & RP 7 & $141 \pm 32$ \\
\hline 16 & $77 \pm 32$ & & \\
\hline 17 & $64 \pm 32$ & & \\
\hline 18 & $102 \pm 38$ & RP 8 & $99 \pm 38$ \\
\hline
\end{tabular}

(a) Indicates samples were collected concurrently. 
TABLE A.17. Tritium Concentrations Along Richland Pumphouse Cross Section and at the Richland Pumphouse, June 23, 1988

\begin{tabular}{|c|c|c|c|}
\hline \multicolumn{2}{|c|}{ Cross Section } & \multicolumn{2}{|c|}{ Richland Pumphouse } \\
\hline $\begin{array}{l}\text { Sample } \\
\text { Number }\end{array}$ & $\begin{array}{c}\text { Concentration, } \\
\mathrm{pCi} / \mathrm{L}\end{array}$ & $\begin{array}{l}\text { Sample } \\
\text { Number } \\
\end{array}$ & $\begin{array}{c}\text { Concentration, } \\
\mathrm{pCi} / \mathrm{L}\end{array}$ \\
\hline EC 1 & $68 \pm 7$ & RP 1 & $72 \pm 7$ \\
\hline $\mathrm{EC} 2$ & $64 \pm 7$ & RP 2 & $69 \pm 7$ \\
\hline EC 3 & $64 \pm 7$ & RP 3 & $70 \pm 7$ \\
\hline EC 4 & $66 \pm 7$ & RP 4 & $64 \pm 7$ \\
\hline EC 5 & $63 \pm 7$ & RP 5 & $84 \pm 7$ \\
\hline EC 6 & $67 \pm 8$ & RP 6 & $83 \pm 7$ \\
\hline EC 7 & $63 \pm 7$ & RP 7 & $72 \pm 7$ \\
\hline EC 8 & $63 \pm 7$ & RP 8 & $59 \pm 7$ \\
\hline EC 9 & $67 \pm 7$ & RP 9 & $79 \pm 7$ \\
\hline EC 10 & $65 \pm 7$ & RP 10 & $76 \pm 8$ \\
\hline WC 1 & $65 \pm 6$ & RP 11 & $69 \pm 7$ \\
\hline WC 2 & $54 \pm 7$ & RP 12 & $73 \pm 7$ \\
\hline WC 3 & $74 \pm 7$ & RP 13 & $73 \pm 7$ \\
\hline WC 4 & $77 \pm 7$ & RP 14 & $81 \pm 7$ \\
\hline WC 5 & $70 \pm 7$ & RP 15 & $64 \pm 7$ \\
\hline WC 6 & $67 \pm 7$ & RP 16 & $61 \pm 7$ \\
\hline WC 7 & $75 \pm 7$ & RP 17 & $62 \pm 7$ \\
\hline WC 8 & $52 \pm 7$ & RP 18 & $69 \pm 7$ \\
\hline WC 9 & $68 \pm 8$ & RP 19 & $69 \pm 7$ \\
\hline WC 10 & $67 \pm 7$ & RP 20 & $70 \pm 7$ \\
\hline
\end{tabular}


TABLE A.18. Tritium Concentrations Along Richland Pumphouse Cross Section and at the Richland Pumphouse, August 5, 1988

\begin{tabular}{|c|c|c|c|}
\hline \multicolumn{2}{|c|}{ Cross Section } & \multicolumn{2}{|c|}{ Richland Pumphouse } \\
\hline $\begin{array}{l}\text { Sample } \\
\text { Number }\end{array}$ & $\begin{array}{c}\text { Concentration, } \\
\mathrm{pC} i / L\end{array}$ & $\begin{array}{l}\text { Sample } \\
\text { Number } \\
\end{array}$ & $\begin{array}{c}\text { Concentration, } \\
\mathrm{pC} i / \mathrm{L}\end{array}$ \\
\hline EC 1 & $73 \pm 7$ & RP 1 & $120 \pm 8$ \\
\hline EC 2 & $76 \pm 7$ & RP 2 & $107 \pm 7$ \\
\hline EC 3 & $68 \pm 7$ & RP 3 & $111 \pm 8$ \\
\hline EC 4 & $73 \pm 7$ & RP 4 & $113 \pm 7$ \\
\hline EC 5 & $74 \pm 7$ & RP 5 & $117 \pm 8$ \\
\hline EC 6 & $68 \pm 7$ & RP 6 & $115 \pm 7$ \\
\hline EC 7 & $75 \pm 7$ & RP 7 & $112 \pm 8$ \\
\hline EC 8 & $70 \pm 7$ & RP 8 & $113 \pm 8$ \\
\hline EC 9 & $79 \pm 7$ & RP 9 & $106 \pm 8$ \\
\hline EC 10 & $77 \pm 7$ & RP 10 & $108 \pm 7$ \\
\hline WC 1 & $74 \pm 8$ &. $\mathrm{P} 11$ & $104 \pm 8$ \\
\hline WC 2 & $02 \pm 7$ & RP 12 & $107 \pm 8$ \\
\hline WC 3 & $67 \pm 7$ & RP 13 & $109 \pm 8$ \\
\hline WC 4 & $64 \pm 7$ & RP 14 & $107 \pm 8$ \\
\hline WC 5 & $62 \pm 7$ & RP 15 & $106 \pm 8$ \\
\hline NC 6 & $55 \pm 7$ & RP 16 & $106 \pm 8$ \\
\hline WC 7 & $65 \pm 7$ & R.P 17 & $99 \pm 7$ \\
\hline WC 8 & $63 \pm 7$ & RP 18 & $104 \pm 8$ \\
\hline WC 9 & $65 \pm 8$ & RP 19 & $107 \pm 8$ \\
\hline WC 10 & $85 \pm 7$ & RP 20 & $100 \pm 7$ \\
\hline
\end{tabular}


IABLE A.19. Tritium Concentrations Along Richland Pumphouse Cross Section and at the Richland Pumphouse, September 29, 1988

\begin{tabular}{|c|c|}
\hline \multicolumn{2}{|c|}{ Cross Section } \\
\hline $\begin{array}{l}\text { Sample } \\
\text { Number }\end{array}$ & $\begin{array}{c}\text { Concentration, } \\
\mathrm{pC} i / \mathrm{L} \\
\end{array}$ \\
\hline EC 1 & $65 \pm 7$ \\
\hline EC 2 & $66 \pm 7$ \\
\hline EC 3 & $57 \pm 7$ \\
\hline EC 4 & $64 \pm 7$ \\
\hline EC 5 & $69 \pm 7$ \\
\hline EC 6 & $69 \pm 7$ \\
\hline EC 7 & $64 \pm 7$ \\
\hline EC 8 & $70 \pm 7$ \\
\hline EC 9 & $67 \pm 7$ \\
\hline EC 10 & $60 \pm 7$ \\
\hline WC 1 & $61 \pm 8$ \\
\hline WC 2 & $61 \pm 7$ \\
\hline WC 3 & $61 \pm 7$ \\
\hline WC 4 & $60 \pm 7$ \\
\hline WC 5 & $60 \pm 7$ \\
\hline WC 6 & $65 \pm 7$ \\
\hline WC 7 & $69 \pm 7$ \\
\hline WC 8 & $84 \pm 7$ \\
\hline WC 9 & $95 \pm 8$ \\
\hline WC 10 & $147 \pm 7$ \\
\hline
\end{tabular}

\begin{tabular}{ccc}
\multicolumn{2}{c}{ Richland } & Pumphouse \\
\cline { 1 - 1 } $\begin{array}{c}\text { SampTe } \\
\text { Number }\end{array}$ & $\begin{array}{c}\text { Concentration, } \\
\text { PCi } / \text { L }\end{array}$ \\
\cline { 1 - 1 } RP 1 & & $188 \pm 8$ \\
RP 2 & & $196 \pm 8$ \\
RP 3 & & $186 \pm 8$ \\
RP 4 & & $187 \pm 8$ \\
RP 5 & & $198 \pm 9$ \\
RP 6 & & $180 \pm 8$ \\
RP 7 & & $175 \pm 7$ \\
RP 8 & & $192 \pm 8$ \\
RP 9 & & $183 \pm 8$ \\
RP 10 & & $172 \pm 7$ \\
RP 11 & & $170 \pm 8$ \\
RP 12 & & $174 \pm 8$ \\
RP 13 & & $163 \pm 8$ \\
RP 14 & & $170 \pm 8$ \\
RP 15 & & $161 \pm 8$ \\
RP 16 & $163 \pm 8$ \\
RP 17 & $170 \pm 8$ \\
RP 18 & $167 \pm 8$ \\
RP 19 & $154 \pm 8$ \\
RP 20 & $154 \pm 8$
\end{tabular}


TABLE A.20. Average Tritium Concentrations Measured Along Cross Sections near the Richland Pumphouse and with the Richland Pumphouse Monitoring System

Date

August 27, 1987

August 31, 1987

September 10, 1987

June 23, 1988

August 5, 1988

September 29, 1988
Average Tritium Concentrations, $\mathrm{pC} i / \mathrm{L}$ Cross Section Richland Pumphouse

78

97

104

164

79

135

$68 \quad 71$

70

109

67

175 
APPENDIX B

ADDITIONAL ANALYSES 


\section{APPENDIX B}

\section{ADDITIONAL ANALYSES}

In addition to the analyses described within the text of this report, selected samples were analyzed for radionuclides other than tritium. These included total alpha, total beta, strontium-90, and isotopic uranium. In addition, $\mathrm{pH}$ and specific conductance were measured in the field at each station during the cross-sectional sampling. Results of these analyses are presented in Tables B.1, B.2, and B.3. 
IABLE B.1. Comparison of Selected Radionulcide Concentrations at Cross Section Stations and the Richland Pumphouse

\begin{tabular}{|c|c|c|c|}
\hline \multirow[b]{2}{*}{ Constituent } & \multirow[b]{2}{*}{ Date } & \multicolumn{2}{|c|}{ Concentration, $\mathrm{pCi} / \mathrm{L}$} \\
\hline & & Cross Section & Richland Pumphouse \\
\hline \multirow[t]{5}{*}{ Alpha } & $9-29-88$ & $0.87 \pm 0.49$ & $0.80 \pm 0.48$ \\
\hline & & $0.56 \pm 0.39$ & $-0.06 \pm 0.20$ \\
\hline & & $0.33 \pm 0.37$ & $0.59 \pm 0.41$ \\
\hline & & $0.70 \pm 0.49$ & $0.11 \pm 0.30$ \\
\hline & & $0.23 \pm 0.30$ & $0.14 \pm 0.34$ \\
\hline \multirow[t]{5}{*}{ Beta } & $9-29-88$ & $1.2 \pm 1.1$ & $0.8 \pm 1.1$ \\
\hline & & $1.4 \pm 1.1$ & $1.6 \pm 1.2$ \\
\hline & & $0.5 \pm 1.0$ & $0.7 \pm 1.0$ \\
\hline & & $2.4 \pm 1.3$ & $1.8 \pm 1.2$ \\
\hline & & $1.3 \pm 1.2$ & $1.8 \pm 1.2$ \\
\hline \multirow[t]{10}{*}{${ }^{90} \mathrm{Sr}$} & $6-23-88$ & $0.19 \pm 0.36$ & $0.11 \pm 0.33$ \\
\hline & & $-0.19 \pm 0.31$ & $0.09 \pm 0.32$ \\
\hline & & $0.13 \pm 0.34$ & $-0.12 \pm 0.31$ \\
\hline & & $-0.24 \pm 0.36$ & $0.26 \pm 0.36$ \\
\hline & & $-0.23 \pm 0.37$ & $0.20 \pm 0.33$ \\
\hline & $9-29-88$ & $0.11 \pm 0.23$ & $0.13 \pm 0.25$ \\
\hline & & $0.02 \pm 0.23$ & $-0.03 \pm 0.23$ \\
\hline & & $-0.24 \pm 0.24$ & $0.08 \pm 0.24$ \\
\hline & & $-0.03 \pm 0.22$ & $-0.10 \pm 0.23$ \\
\hline & & $0.13 \pm 0.27$ & $-0.27 \pm 0.19$ \\
\hline \multirow[t]{10}{*}{${ }^{234} u$} & $6-23-88$ & $0.23 \pm 0.05$ & $0.16 \pm 0.05$ \\
\hline & & $0.19 \pm 0.05$ & $0.15 \pm 0.04$ \\
\hline & & $0.19 \pm 0.04$ & $0.16 \pm 0.04$ \\
\hline & & $0.19 \pm 0.05$ & $0.16 \pm 0.04$ \\
\hline & & $0.18 \pm 0.05$ & $0.17 \pm 0.05$ \\
\hline & $9-29-88$ & $0.22 \pm 0.05$ & $0.19 \pm 0.05$ \\
\hline & & $0.17 \pm 0.04$ & $0.20 \pm 0.05$ \\
\hline & & $0.17 \pm 0.04$ & $0.15 \pm 0.04$ \\
\hline & & $0.18 \pm 0.04$ & $0.18 \pm 0.05$ \\
\hline & & $0.18 \pm 0.04$ & $0.19 \pm 0.05$ \\
\hline \multirow[t]{10}{*}{$238 \mathrm{U}$} & $6-23-88$ & $0.16 \pm 0.04$ & $0.13 \pm 0.04$ \\
\hline & & $0.13 \pm 0.04$ & $0.12 \pm 0.03$ \\
\hline & & $0.14 \pm 0.04$ & $0.13 \pm 0.04$ \\
\hline & & $0.15 \pm 0.04$ & $0.16 \pm 0.04$ \\
\hline & & $0.14 \pm 0.04$ & $0.15 \pm 0.04$ \\
\hline & $9-29-88$ & $0.19 \pm 0.05$ & $0.16 \pm 0.04$ \\
\hline & & $0.11 \pm 0.03$ & $0.14 \pm 0.04$ \\
\hline & & $0.11 \pm 0.03$ & $0.15 \pm 0.04$ \\
\hline & & $0.14 \pm 0.04$ & $0.14 \pm 0.04$ \\
\hline & & B.2 & \\
\hline
\end{tabular}


TABLE B.2. Richland Ferry Landing Cross Section PH and Conductivity, 1987

\begin{tabular}{|c|c|c|c|c|c|c|}
\hline \multirow{2}{*}{$\begin{array}{l}\text { Station } \\
\text { Number }\end{array}$} & \multicolumn{2}{|c|}{ August 27,1987} & \multicolumn{2}{|c|}{ August 31,1987} & \multicolumn{2}{|c|}{ September 1987} \\
\hline & $\mathrm{pH}$ & Conductivity & $\mathrm{pH}$ & Conductivity & $\mathrm{pH}$ & Conductivity \\
\hline 1 & $\mathrm{BC}^{(\mathrm{a})}$ & Shoreline & $\mathrm{BC}$ & Shoreline & $\mathrm{BC}$ & Shoreline \\
\hline 2 & 7.8 & 119 & 8.3 & 131 & $-(b)$ & 137 \\
\hline 3 & 8.2 & 112 & 8.1 & 119 & _ & 129 \\
\hline 4 & 8.1 & 104 & 8.0 & 116 & _ & 118 \\
\hline 5 & 7.9 & 100 & 7.9 & 106 & _ & 126 \\
\hline 6 & 7.9 & 98 & 7.7 & 103 & - & 129 \\
\hline 7 & 7.5 & 99 & 7.6 & 100 & _. & 128 \\
\hline 8 & 7.5 & 100 & 7.5 & 98 & - & 129 \\
\hline 9 & 7.5 & 100 & 7.6 & 102 & - & 128 \\
\hline 10 & 7.6 & 100 & 7.6 & 99 & - & 128 \\
\hline 11 & 7.6 & 98 & 7.5 & 99 & - & 128 \\
\hline 12 & 7.6 & 100 & 7.5 & 99 & _- & 128 \\
\hline 13 & 7.7 & 104 & 7.5 & 98 & - & 130 \\
\hline 14 & 7.7 & 107 & 7.6 & 97 & - & 128 \\
\hline 15 & 7.7 & 106 & 7.6 & 102 & - & 128 \\
\hline 16 & 7.8 & 119 & 7.6 & 108 & - & 130 \\
\hline 17 & Shor & & 7.7 & 114 & _ & 149 \\
\hline 18 & & & 8.0 & 155 & _ & 192 \\
\hline
\end{tabular}

(a) Benton County.

(b) $\mathrm{pH}$ meter malfunction. 
TABLE B.3. Richland Pumphouse Cross Section pH and Conductivity, 1988

\begin{tabular}{|c|c|c|c|c|c|c|}
\hline \multirow{2}{*}{$\begin{array}{l}\text { Station } \\
\text { Number }\end{array}$} & \multicolumn{2}{|c|}{ June 23,1988} & \multicolumn{2}{|c|}{ August 5,1988} & \multicolumn{2}{|c|}{ September 29,1988} \\
\hline & $\mathrm{pH}$ & Conductivity & $\mathrm{pH}$ & Conductivity & $\mathrm{pH}$ & Conductivity \\
\hline$E C 1^{(a)}$ & 8.3 & 122 & 7.6 & 130 & 7.8 & 161 \\
\hline EC 2 & 8.2 & 103 & 7.7 & 108 & 7.9 & 140 \\
\hline EC 3 & 8.1 & 95 & 7.5 & 97 & 7.9 & 132 \\
\hline EC 4 & 8.1 & 91 & 7.4 & 94 & 7.9 & 128 \\
\hline EC 5 & 8.0 & 88 & 7.6 & 94 & 7.9 & 128 \\
\hline EC 6 & 8.0 & 86 & 7.6 & 94 & 7.9 & 127 \\
\hline EC 7 & 8.0 & 87 & 7.8 & 99 & 7.9 & 127 \\
\hline EC 8 & 8.0 & 89 & 7.8 & 99 & 7.9 & 127 \\
\hline EC 9 & 8.2 & 91 & 8.1 & 99 & 7.9 & 127 \\
\hline EC 10 & 8.2 & 92 & ${ }^{(b)}$ & 112 & 8.0 & 126 \\
\hline WC 1 & 8.2 & 91 & - & 139 & 8.1 & 126 \\
\hline WC 2 & 8.3 & 94 & - & 137 & 8.0 & 125 \\
\hline WC 3 & 8.2 & 96 & _ & 134 & 7.9 & 125 \\
\hline WC 4 & 8.4 & 97 & - & 130 & 7.9 & 125 \\
\hline WC 5 & 8.4 & 98 & _ & 127 & 7.9 & 124 \\
\hline WC 6 & 8.5 & 98 & - & 136 & 8.0 & 124 \\
\hline WC 7 & 8.3 & 90 & _ & 143 & 8.0 & 123 \\
\hline WC 8 & 8.3 & 88 & - & 145 & 8.0 & 123 \\
\hline WC 9 & 8.3 & 89 & - & 145 & 8.0 & 123 \\
\hline WC 10 & 8.5 & 90 & - & 147 & 8.4 & 127 \\
\hline
\end{tabular}

(a) $E C=$ East Channel beginning at Frankl in County Shoreline.

$W C=$ West Channel ending at Benton County Shoreline.

(b) Instrument failure. 


\section{APPENDIX C}

QUALITY CONTROL/DUPLICATE SAMPLE RESULTS 


\section{APPENDIX C}

\section{QUALITY CONTROL/DUPLICATE SAMPLE RESULTS}

Results of duplicate samples, collected for quality control purposes during each cross-section sampling activity, are presented in Table C.l. Agreement during both years was very good, well within the range of variability expected for analysis of tritium at environmental levels. Figures C.1 through C.6 graphically illustrate the comparability of the duplicate sample results. Evident in both the data table and figures is the enhanced sensitivity in the analytical method used during 1988 as opposed to that used in 1987. This reduction in the uncertainty associated with each sample result allowed for more meaningful comparisons and a more accurate assessment of the distribution of tritium in Columbia River water at the Richland Pumphouse. 
TABLE C.1. Quality Control: Duplicate Sample Results

\begin{tabular}{|c|c|c|c|}
\hline Date & $\begin{array}{l}\text { Sample } \\
\text { Number }\end{array}$ & \multicolumn{2}{|c|}{ Tritium Concentration, $\mathrm{PCi} / \mathrm{L}$} \\
\hline \multirow[t]{4}{*}{$08 / 27 / 87$} & RP 04A & $93 \pm 32$ & $45 \pm 32$ \\
\hline & A 05.6 & $90 \pm 32$ & $77 \pm 32$ \\
\hline & A 10.6 & $80 \pm 32$ & $64 \pm 32$ \\
\hline & A 15.6 & $51 \pm 32$ & $64 \pm 32$ \\
\hline \multirow[t]{3}{*}{$08 / 31 / 87$} & B 04.6 & $112 \pm 32$ & $102 \pm 32$ \\
\hline & B 16.6 & $96 \pm 32$ & $96 \pm 38$ \\
\hline & RP 05B & $154 \pm 38$ & $173 \pm 38$ \\
\hline \multirow[t]{4}{*}{$09 / 10 / 87$} & C 02.6 & $122 \pm 38$ & $106 \pm 38$ \\
\hline & C 08.6 & $42 \pm 32$ & $74 \pm 32$ \\
\hline & C 15.6 & $38 \pm 38$ & $70 \pm 38$ \\
\hline & RP $05 C$ & $138 \pm 38$ & $166 \pm 38$ \\
\hline \multirow[t]{5}{*}{$06 / 23 / 88$} & EC $07 \mathrm{~A}$ & $63 \pm 7$ & $59 \pm 7$ \\
\hline & WC 02A & $54 \pm 7$ & $60 \pm 7$ \\
\hline & WC O9A & $68 \pm 8$ & $73 \pm 8$ \\
\hline & RP $04 \mathrm{~A}$ & $64 \pm 7$ & $66 \pm 7$ \\
\hline & RP $15 A$ & $64 \pm 7$ & $64 \pm 7$ \\
\hline \multirow[t]{5}{*}{$08 / 05 / 88$} & EC 05B & $74 \pm 7$ & $68 \pm 7$ \\
\hline & WC 03B & $67 \pm 7$ & $64 \pm 7$ \\
\hline & WC 08B & $63 \pm 7$ & $66 \pm 7$ \\
\hline & RP 05B & $117 \pm 8$ & $113 \pm 7$ \\
\hline & RP 18B & $104 \pm 8$ & $101 \pm 8$ \\
\hline \multirow[t]{5}{*}{$09 / 29 / 88$} & EC O6B & $69 \pm 7$ & $69 \pm 7$ \\
\hline & WC $06 C$ & $65 \pm 7$ & $67 \pm 7$ \\
\hline & WC $09 C$ & $95 \pm 7$ & $100 \pm 7$ \\
\hline & RP $06 \mathrm{C}$ & $180 \pm 8$ & $192 \pm 8$ \\
\hline & RP $16 C$ & $163 \pm 8$ & $163 \pm 8$ \\
\hline
\end{tabular}




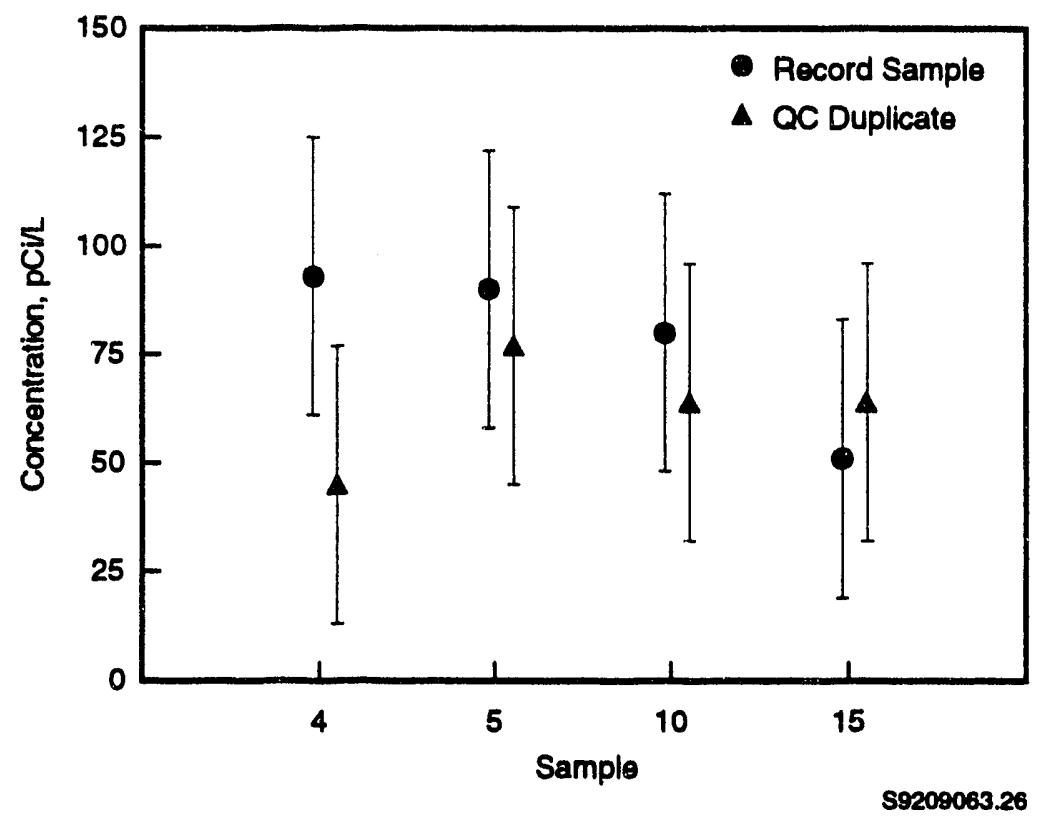

FIGURE C.1. Duplicate Sample Tritium Analysis, August 27, 1987

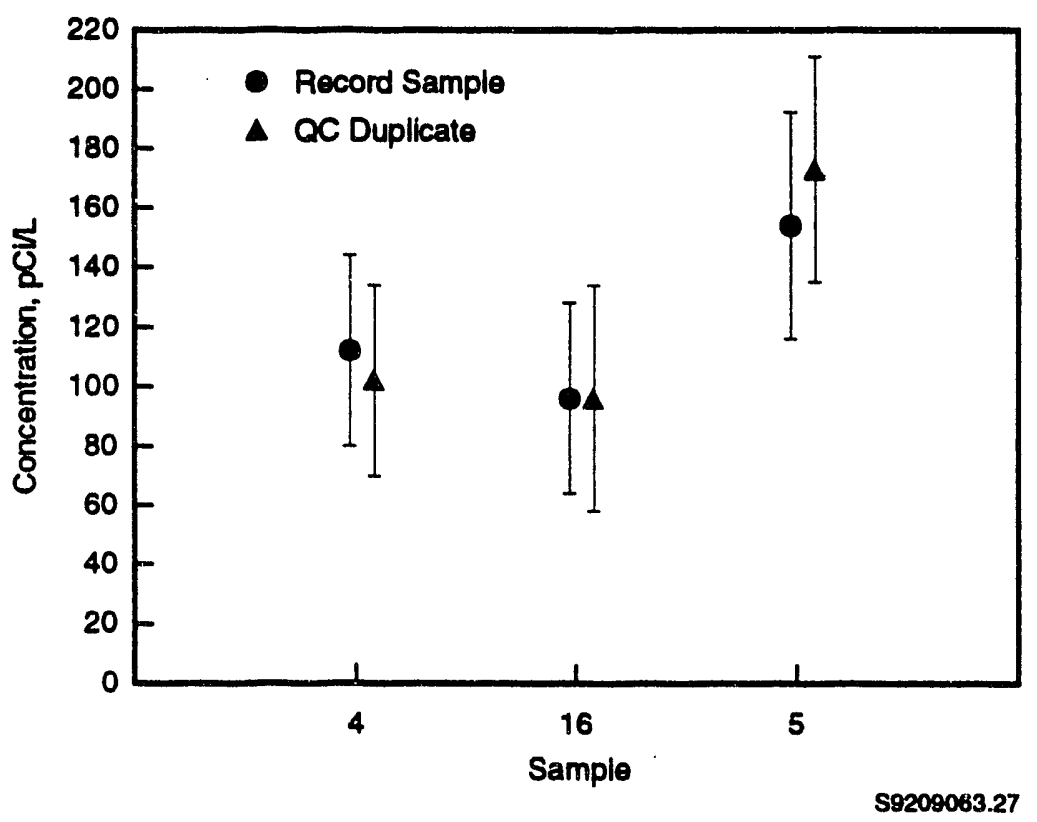

FIGURE C.2. Duplicate Sample Tritium Analysis, August 31, 1987

C.3 


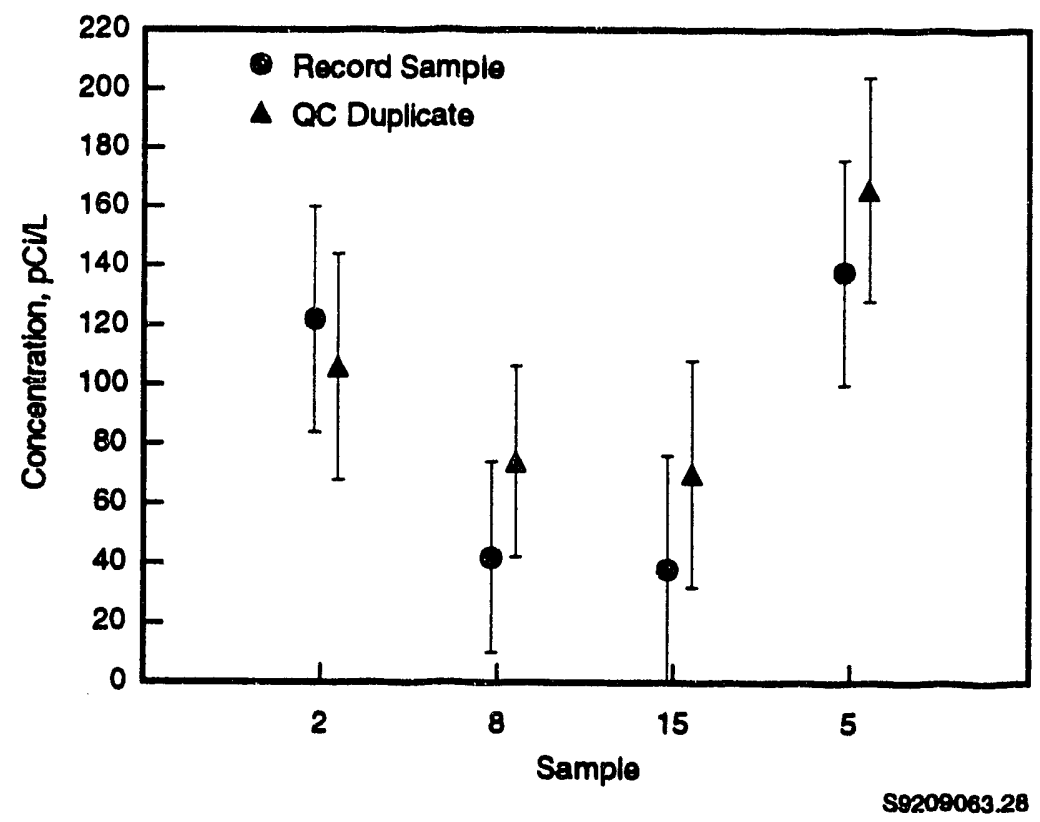

FIGURE C.3. Duplicate Sample Tritium Analysis, September 10, 1987

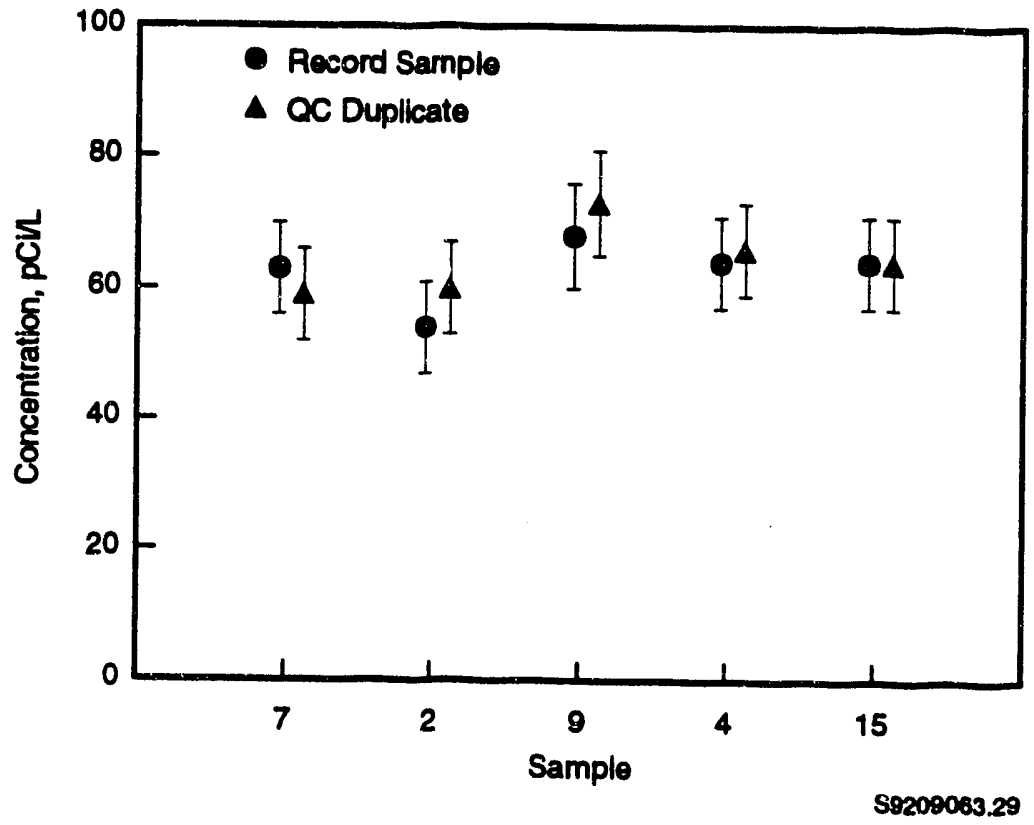

EIGURE C.4. Duplicate Sample Tritium Analysis, June 23, 1988

C. 4 


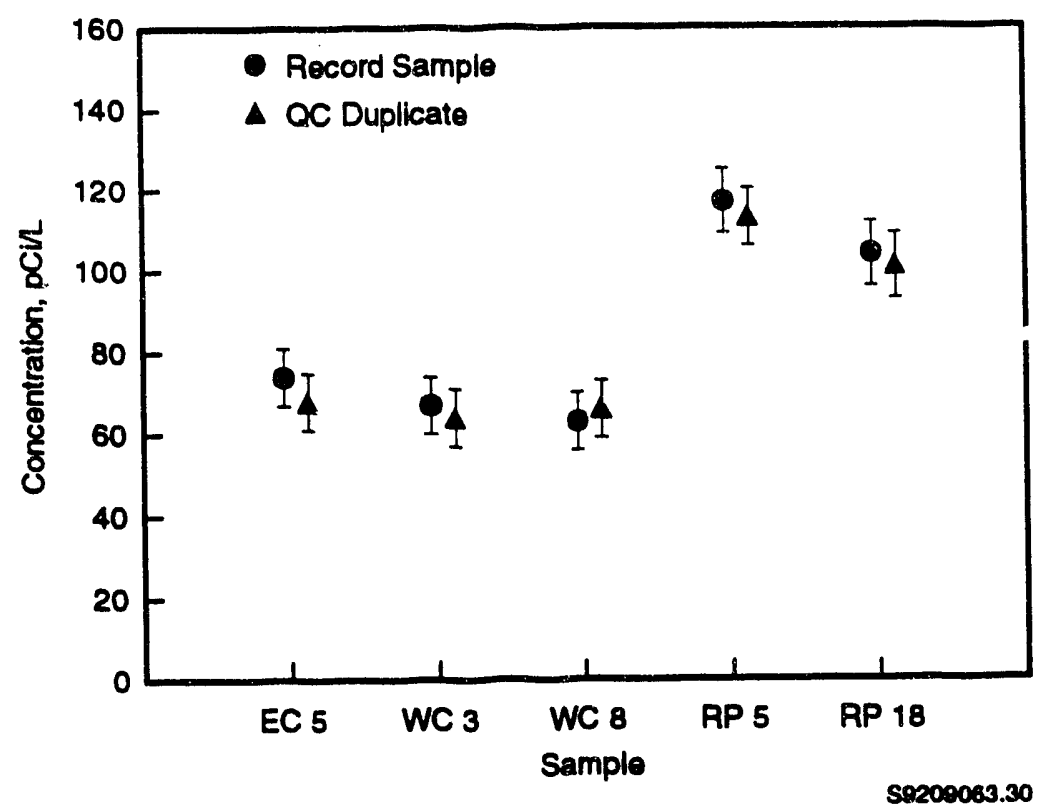

FIGURE C.5. Duplicate Sample Tritium Analysis, August 5, 1988

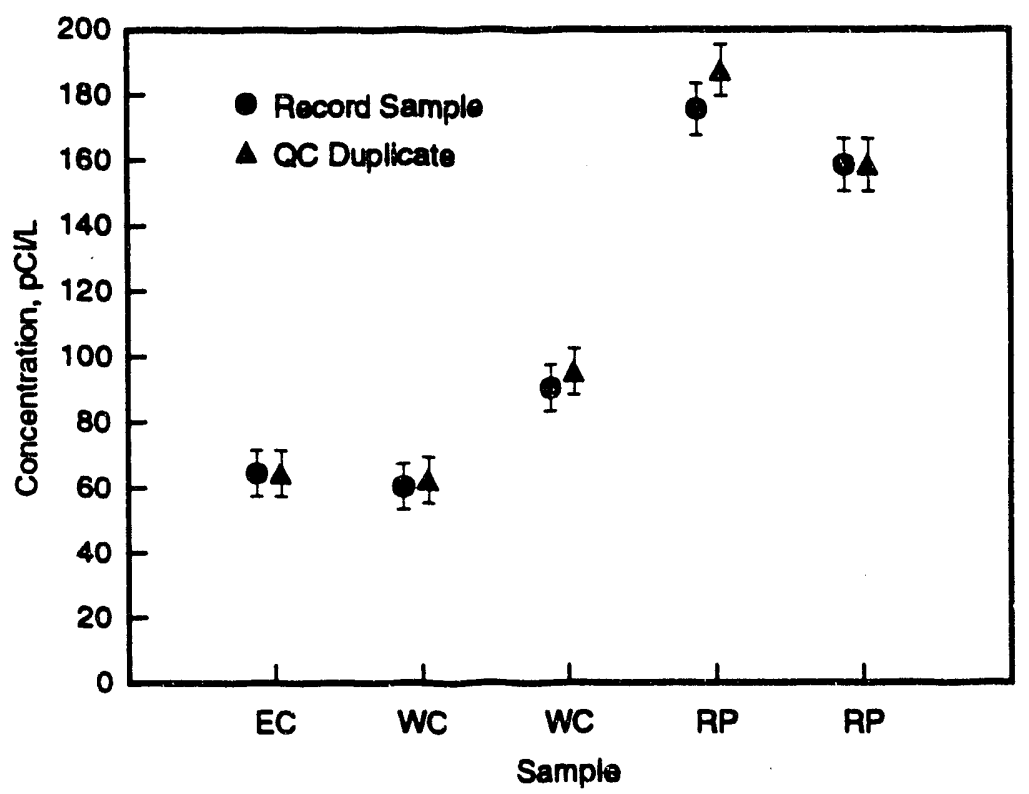

59209063.31

FIGURE C.6. Duplicate Sample Tritium Analysis, September 29, 1988

C. 5 


\section{DISTRIBUTION}

No. of

Copies

OFFSITE

2 DOE/Office of Scientific and Technical Information

J. Erickson

Washington State Department of Health

Division of Radiation Protection

Airdustrial Center

Building 5, M.S. C-13

O1ympia, WA 98503

\section{ONSITE}

3 DOE Richland Field Office

R. F. Brich

E. D. Goller

M. W. Tierman

8 Westinghouse Hanford Company

L. P. Diediker

J. J. Dorian

E. M. Greager

L. C. Hulstrom

J. W. Schmidt

S. E. Vukelich

S. G. Weiss

Public Reading Room
No. of

Copies

48 Pacific Northwest Laboratory

E. J. Antonio

R. W. Bryce

T. A. Cooper

R. L. Dirkes (25)

S. L. Friant

R. H. Gray

R. W. Hanf, Jr.

P. M. Irving

R. E. Jaquish

R. E. Lundgren

E. W. Lusty

T. M. Poston

W. H. Walters

H. E. Westerdah1

R. K. Woodruff

Publishing Coordination SESP Historical Files/

R. K. Woodruff (2)

Technical Report Files (5)

\section{Routing}

R. M. Ecker

M. J. Graham

C. J. Hostetler

R. L. Skaggs

C. S. Sloane

P. C. Hays (1ast) 

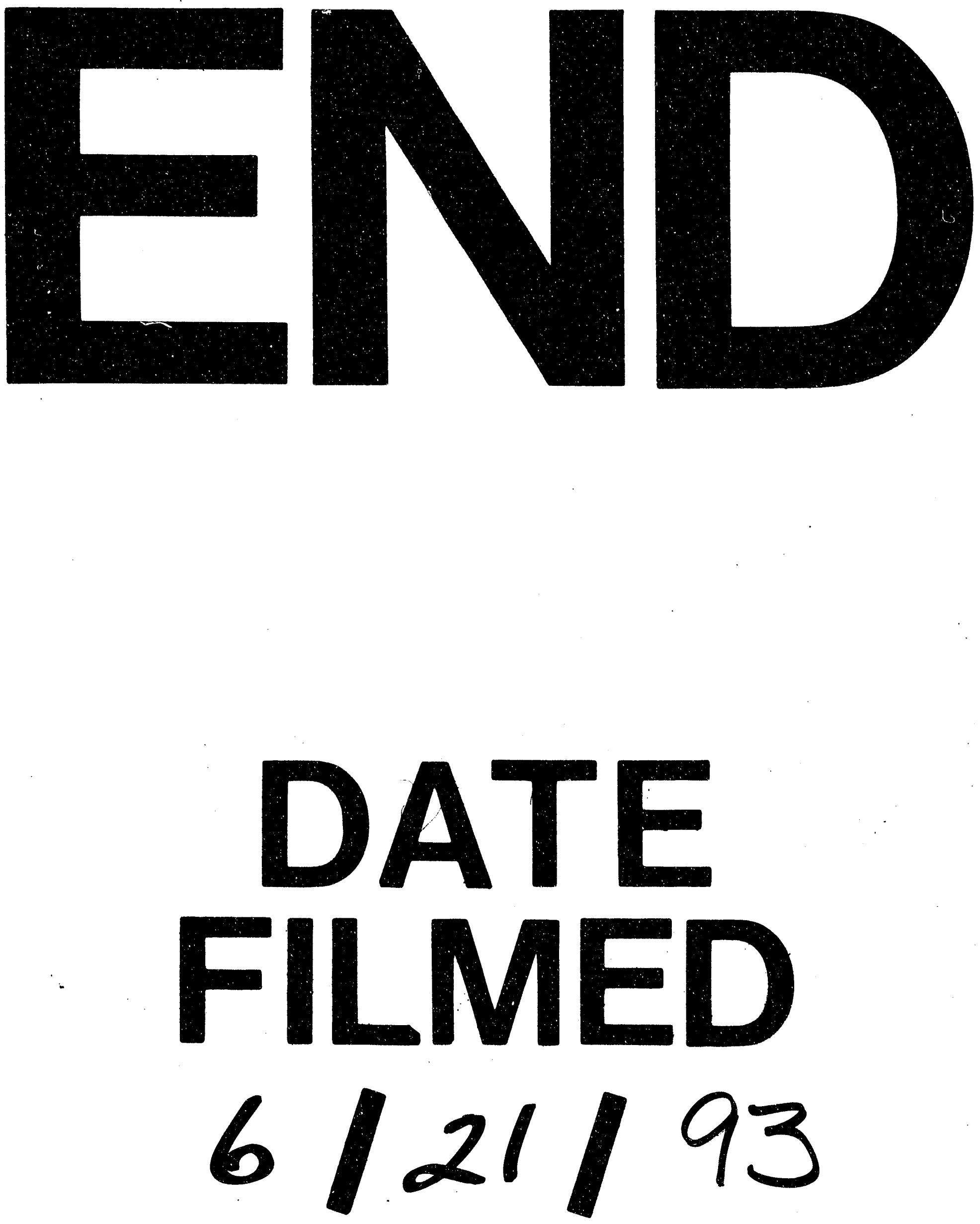
